\title{
THE IMPACT OF ALTERNATIVE SORBENTS AS COMPARED TO MONOSODIUM TITANATE ON THE DEFENSE WASTE PROCESSING FACILITY
}

C.C. Herman

T.B. Edwards

D.K. Peeler

May 2004 
This document was prepared in conjunction with work accomplished under Contract No. DE-AC09-96SR18500 with the U. S. Department of Energy.

\section{DISCLAIMER}

This report was prepared as an account of work sponsored by an agency of the United States Government. Neither the United States Government nor any agency thereof, nor any of their employees, makes any warranty, express or implied, or assumes any legal liability or responsibility for the accuracy, completeness, or usefulness of any information, apparatus, product or process disclosed, or represents that its use would not infringe privately owned rights. Reference herein to any specific commercial product, process or service by trade name, trademark, manufacturer, or otherwise does not necessarily constitute or imply its endorsement, recommendation, or favoring by the United States Government or any agency thereof. The views and opinions of authors expressed herein do not necessarily state or reflect those of the United States Government or any agency thereof.

This report has been reproduced directly from the best available copy.

Available for sale to the public, in paper, from: U.S. Department of Commerce, National Technical Information Service, 5285 Port Royal Road, Springfield, VA 22161, phone: (800) 553-6847, fax: (703) 605-6900

email: orders@ntis.fedworld.gov

online ordering: http://www.ntis.gov/help/index.asp

Available electronically at http://www.osti.gov/bridge

Available for a processing fee to U.S. Department of Energy and its contractors, in paper, from: U.S. Department of Energy, Office of Scientific and Technical Information, P.O. Box 62, Oak Ridge, TN 37831-0062,

phone: (865)576-8401,

fax: (865)576-5728

email: $\underline{\text { reports@ adonis.osti.gov }}$ 
Key Words: DWPF, MST, Engineered MST, IS-MIO, Actinide Removal

Retention: Permanent

\section{THE IMPACT OF ALTERNATIVE SORBENTS AS COMPARED TO MONOSODIUM TITANATE ON THE DEFENSE WASTE PROCESSING FACILITY}

C.C. Herman

T.B. Edwards

D.K. Peeler

May 2004

Immobilization Technology Section

Savannah River National Laboratory

Savannah River National Laboratory

Aiken, SC 29808 
This page was intentionally left blank 
This page was intentionally left blank 
WSRC-TR-2004-00200

Revision 0

\section{EXECUTIVE SUMMARY}

Several alternatives to the use of monosodium titanate (MST) are being examined to affect enhanced performance in both the Salt Waste Processing Facility (SWPF) and the Actinide Removal Process (ARP) facilities. The currently available (and baseline) material, MST, exhibits lower capacity and removal kinetics, particularly for plutonium, than that desired in the pretreatment of SRS waste solutions. An increase in the removal capacity and kinetics would reduce the risk of batches of decontaminated supernate not meeting saltstone waste acceptance criteria. Enhanced performance would also serve to increase processing throughput by decreasing the required batch contact time. However, the introduction of any actinide removal/sorbent stream results in downstream impacts to the Defense Waste Processing Facility’s (DWPF) Chemical Process Cell (CPC) and projected operating windows - such impacts are the focus of this report. The specific alternative sorbent streams evaluated were: (1) optimized MST, (2) Engineered MST Case A (internal gelation process), (3) Engineered MST Case B (internal hydrolysis process), and (4) In-Situ Mixed Iron Oxide (ISMIO). All of the alternative sorbents were compared to the baseline MST stream.

Based on the assessments performed and the assumptions made for this study, all of the options being considered are plausible from a DWPF CPC and glass formulation perspective. However, additional testing and evaluation is warranted to fully understand the impacts on DWPF processing.

Compared to the MST-baseline sorbent and process, no increase in acid addition demand is expected for the alternative sorbents. The IS-MIO stream introduces reduced iron as part of the incoming DWPF stream. This can impact glass REDOX in DWPF. However, the quantity is very small and can likely be accommodated. SRTC testing should be performed to demonstrate this hypothesis.

Of greatest concern are the potential impacts of the alternative sorbents on CPC processing, which can not be ascertained without actual testing of the sorbent materials. This includes rheology, antifoam effectiveness, potential generation of hydrogen, and processing time. Based on the limited data, Engineered MST Case B would appear to have a potential for the largest impact due to the high total and insoluble solids content.

With respect to projected operating windows, the Optimized MST, Engineered MST Case A, and ISMIO options resulted in upper waste loadings (WLs) of 42, 42, and 40\%, respectively, as compared to the MST baseline of 43\% WL. The use of Frit 202 with the Engineered MST Case B sorbent resulted in complete elimination of the operating window. However, use of Frit 433 with the Engineered MST Case B sorbent result in a higher projected upper WL of $49 \%$ as compared to the MST baseline. Predictions of liquidus temperature restricted access to higher WLs for all systems evaluated. Although a potentially significant advantage in terms of the projected WL is shown for the Engineered MST Case B option with Frit 433 relative to the Frit 202-based systems, caution should be used given the projected operating windows for the other alternatives could possibly be improved through the use of strategic frit development approaches. In fact, a high probability exists that the "WL gap" between the different systems could be minimized by strategic frit development efforts. From a glass formulation perspective, the greatest concern is the potential impact on melter processing (i.e., melt rate and waste throughput).

Projections regarding the total number of cans produced suggested very little differences among the various options and negligible difference from the baseline MST. The maximum difference among the options in terms of annual canister count was an increase of approximately 26 for the IS-MIO case which are not viewed as significant given the assumptions made and the fact that specific frit development efforts were not undertaken. 


\section{TABLE OF CONTENTS}

EXECUTIVE SUMMARY ……………………………..............................................

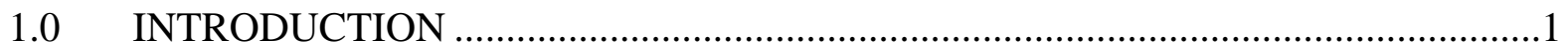

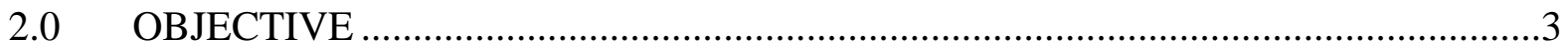

3.0 DEFINITION OF BASELINE FLOWSHEET AND ALTERNATIVE WASTE

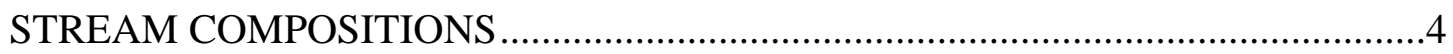

3.1 SB3 Sludge Composition .........................................................................................

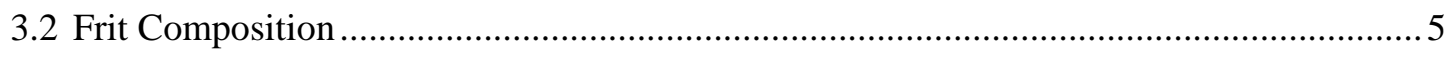

3.3 Alternative Sorbent Compositions/Cases ……………………………………….....

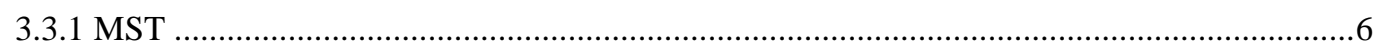

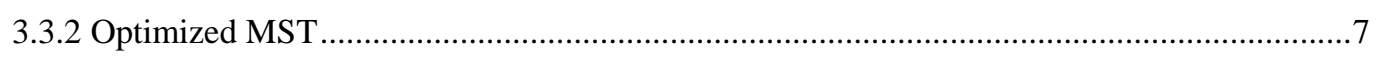

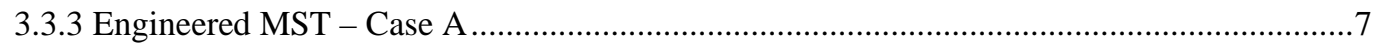

3.3.4 Engineered MST - Case B ...................................................................................

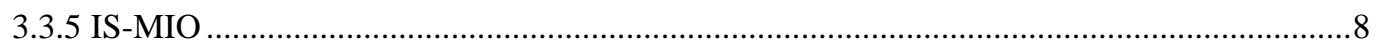

4.0 MATERIAL BALANCE BLENDING STRATEGIES AND ASSUMPTIONS ...........9

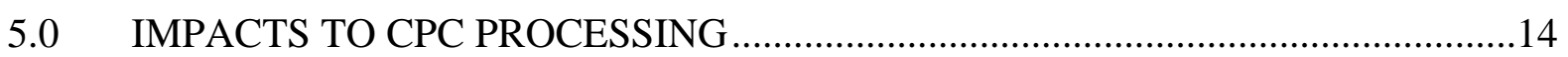

6.0 IMPACTS TO GLASS PROPERTIES: THE STRATEGY OR APPROACH ...........18

7.0 MEASUREMENT ACCEPTABILITY REGION (MAR) LIMITS USED FOR THE

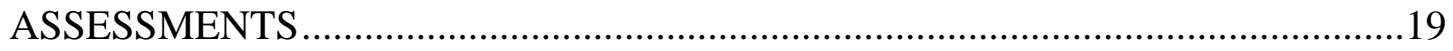

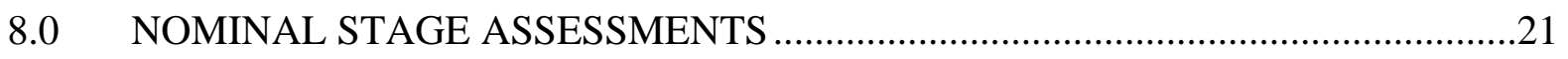

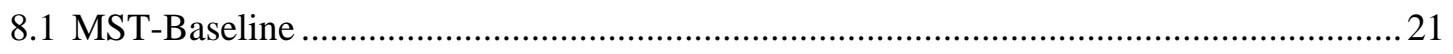

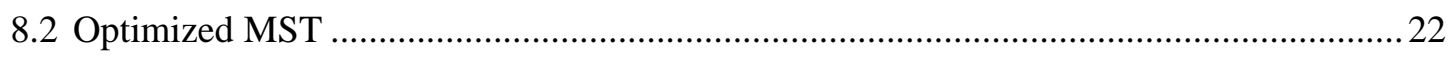

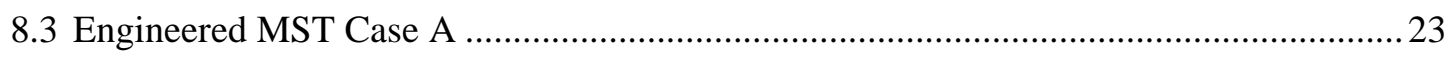

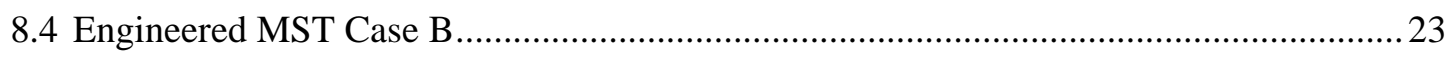

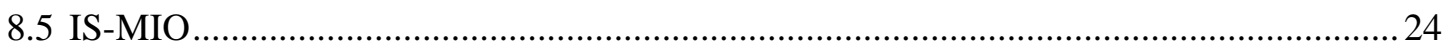

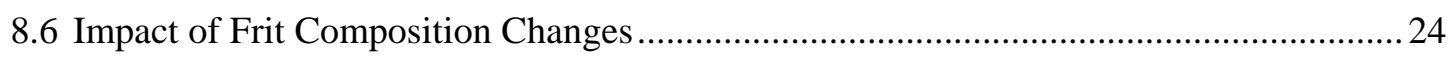

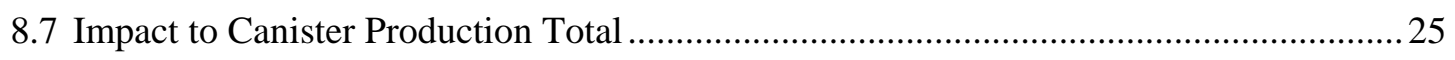

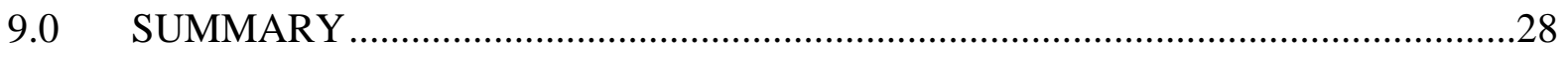

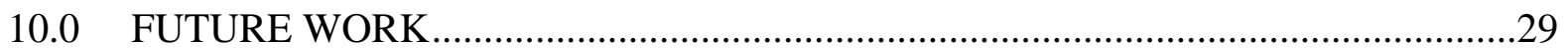

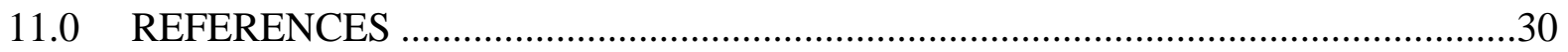

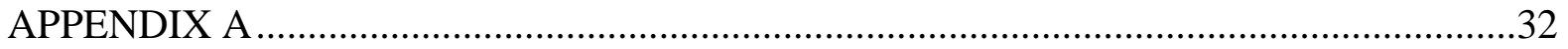

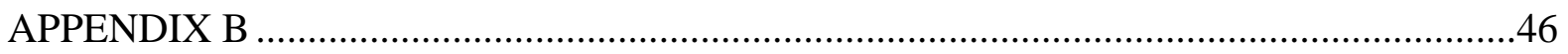




\section{LIST OF TABLES}

Table 3-1. Projected SB2/SB3 Compositions (oxide basis, wt\%).................................................. 5

Table 3-2. Nominal Composition (with acceptable tolerance ranges) of Frit 202. ............................ 6

Table 3-3. Nominal Compositions of MST and the Alternative Sorbents. ......................................... 7

Table 4-1. Composition of SWPF Streams to Be Transferred to DWPF ............................................10

Table 4-2. Baseline MST SWPF Process Flow Rates to DWPF ......................................................... 10

Table 4-3. Sorbent Compositions Projected Annual Use ................................................................... 10

Table 4-4. Estimated Volume of SWPF Stream to Be Processed in DWPF .....................................12

Table 4-5. Estimated Properties of Baseline Sludge and SWPF Streams. ..........................................13

Table 4-6. Resulting SRAT Products for the MST and Alternative Sorbents.....................................13

Table 5-1. Inputs for the DWPF Acid Addition Calculation.......................................................... 16

Table 8-1. Nominal Stage Assessment Using MAR Criteria. ......................................................... 21

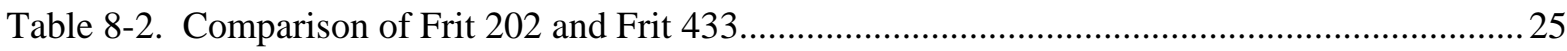

Table 8-3. Maximum WL, Sludge Volume, and Estimated \# of Canisters for Each Option. .............27 


\section{ACRONYMS}

\begin{tabular}{ll} 
ARP & Actinide Removal Process \\
CPC & Chemical Processing Cell \\
DF & decontamination factor \\
DWPF & Defense Waste Processing Facility \\
$\Delta \mathrm{G}_{\mathrm{p}}$ & preliminary glass dissolution estimator based on free energy of hydration \\
IS-MIO & In-Situ Mixed Iron Oxide \\
ITP & In-Tank Precipitation \\
NL [B] & normalized boron release (in g/L) \\
MAR & Measurement Acceptability Region \\
MFT & Melter Feed Tank \\
MST & monosodium titanate \\
ORNL & Oak Ridge National Laboratory \\
PCCS & Product Composition Control System \\
PCT & product consistency test \\
PHA & precipitate hydrolysis aqueous \\
REDOX & REDuction/OXidation \\
SB & sludge batch \\
SRAT & Sludge Receipt and Adjustment Tank \\
SRS & Savannah River Site \\
SRTC & Savannah River Technology Center \\
SWPF & Salt Waste Processing Facility \\
SME & Slurry Mix Evaporator \\
$\mathrm{T}_{\mathrm{L}}$ & liquidus temperature \\
$\eta$ & viscosity \\
WL & waste loading \\
WPT & Waste Processing Technology \\
\hline
\end{tabular}


WSRC-TR-2004-00200

Revision 0

\subsection{INTRODUCTION}

There are approximately 36 million gallons of high-level waste (HLW) stored in 49 tanks at the Savannah River Site (SRS) in South Carolina. This waste, which is a product of the cold-war era, contains a number of radioactive isotopes of a large number of elements such as cesium (Cs), strontium (Sr), and actinide elements (such as neptunium (Np), uranium (U), plutonium (Pu), and americium (Am)). The waste is composed of sludge (c. 10\%) and alkaline water-based supernate (c. 90\%). A portion of the supernate is stored as a saltcake resulting from the evaporation of water from the HLW supernates (Cathey 2003 and Caldwell et al. 2002). Upon retrieval of the saltcake by dissolution in inhibited waste, the total inventory of supernate and dissolved saltcake that will require pretreatment and disposal is expected to be about 80 million gallons.

The baseline plan for the waste treatment requires the sludge to be sent to the Defense Waste Processing Facility (DWPF) for vitrification into borosilicate glass, while all the remaining supernate (including the dissolved saltcake) processes through the Salt Waste Processing Facility (SWPF). The SWPF will separate Cs, Sr, and actinides into a high-level stream, to be vitrified in the DWPF, while the decontaminated solution will be disposed of in the Saltstone Production Facility. An alternative accelerated baseline approach (Cathey 2003 and Caldwell et al. 2002) would require only the high-curie portion of the supernate to be processed in the SWPF, while the remaining low-curie supernate would either be treated for $\mathrm{Sr}$ and actinide removal within the Actinide Removal Process (ARP) facility or sent directly to the Saltstone Grout Facility, if its curie content is sufficiently low. Acceleration of waste disposal at the SRS requires materials that exhibit increased loading capacities and removal kinetics for ${ }^{90} \mathrm{Sr}$ and alpha-emitting radionuclides compared to the baseline material, monosodium titanate (MST).

MST is the baseline material for Sr/actinide removal for the SRS SWPF and ARP facilities. MST is an inorganic sorbent originally developed for use in the In-Tank Precipitation (ITP) process. Key specifications of the MST for ITP included: (1) a high decontamination factor (DF) for strontium, (2) a relatively narrow particle size distribution (1 - 35.5 microns), and (3) supplied as an aqueous suspension containing sodium hydroxide and sodium nitrite as corrosion inhibitors. A high strontium DF requirement was specified to ensure adequate ${ }^{90} \mathrm{Sr}$ removal. An upper particle size constraint was specified to reduce rapid settling of the MST particles in the ITP processing tank. A lower particle size constraint was specified to reduce plugging of the cross flow filter from fine particles. The addition of sodium hydroxide and sodium nitrite was specified to prevent corrosion of the cold chemical storage tank and the ITP processing tank.

The proposed SWPF and existing ARP facilities have significantly different reactor configurations and process cycle times compared to those proposed for the now shutdown ITP operation. In particular, contact times between the MST and the alkaline waste solutions in the SWPF and ARP will be 24 hours versus approximately 2 weeks for the ITP process. Increased waste characterization data indicate that alpha removal characteristics (principally plutonium removal) represent a greater challenge than those for ${ }^{90} \mathrm{Sr}$. Based on recent testing at Savannah River Technology Center (SRTC) (Hobbs 2002), the performance of MST to efficiently and rapidly remove alpha-emitting radionuclides serves as the limiting factor in sizing the equipment and determining the operational throughput. Even higher alpha activities are projected for the SWPF and ARP operations as a result of initiatives to accelerate the disposal of HLW at the SRS. Due to the limited solubility of titanium in HLW borosilicate glass (Lorier and Jantzen 2003), there may be limits on the amount of MST that can be used in SWPF and ARP facilities. Consequently, the need exists for an improved Sr/alpha removal material that exhibits increased actinide removal capacity and kinetics. 
SRTC's Waste Processing Technology (WPT) Section is evaluating alternative sorbents to affect enhanced performance in both the SWPF and the ARP facilities. A four-fold or more increase in the removal capacity and more rapid sorption kinetics would reduce the risk that batches of decontaminated supernate would not meet saltstone waste acceptance criteria. Enhanced removal kinetics would also serve to increase processing throughput by decreasing the required batch contact time to less than 24 hours.

In this study, four alternative sorbents/cases are assessed with respect to potential downstream impacts to the DWPF and are compared to the MST-baseline process. These alternative sorbents/cases are: (1) optimized MST case, (2) Engineered MST sorbent - Case A, (3) Engineered MST sorbent - Case B, and (4), the In-Situ Mixed Iron Oxide (IS-MIO) case. The potential downstream impacts on the Chemical Process Cell (CPC), projected operating windows, and canister production totals for DWPF are the focus of this report. The impacts are assessed relative to the current MST baseline flowsheet. The CPC and operating window impacts are assessed by appealing to models that relate composition to process and product quality properties. Since there are currently no models relating composition to melt rate, the comparison of canister production rely more heavily on underlying assumptions. It should be noted that no experimental work was performed as part of this assessment. 
WSRC-TR-2004-00200

Revision 0

\subsection{OBJECTIVE}

The objective of this report is to evaluate the relative impacts of the alternative sorbent materials/cases on the DWPF. The impacts are assessed relative to the baseline SWPF process using MST sorbent and include processing issues associated primarily with the CPC, projected glass operating windows (which are based on model predictions and are represented in terms of waste loading (WL) intervals), and canister production totals. The specific sorbent streams to be evaluated include: (1) optimized MST, (2) Engineered MST Case A (internal gelation process), (3) Engineered MST Case B (internal hydrolysis process), and (4) IS-MIO.

The primary focus of the CPC evaluations is the potential impact to the DWPF acid addition strategy and/or the influences of the SWPF streams on slurry rheology and other processing properties. In terms of the projected glass operating windows, current processing and product performance models are used to estimate the waste loading interval over which the various flowsheets could potentially be processed. The waste loadings presented provide a relative measure of the impact of each sorbent and associated volume on the operational flexibility and potential maximum waste loadings that could be attained in DWPF. Based on the projected operating windows, assessments are made with respect to potential impacts to canister production totals - without the impact of melt rate factored into this assessment. 
WSRC-TR-2004-00200

Revision 0

\subsection{DEFINITION OF BASELINE FLOWSHEET AND ALTERNATIVE WASTE STREAM COMPOSITIONS}

To assess the impacts of the alternative sorbents on the DWPF process, one must first select a specific sludge/frit system. Once the sludge/frit system is selected, the MST baseline flowsheet can be established. For this assessment, the Frit 202 - Sludge Batch 3 (SB3) system with the SWPF stream containing MST will serve as the baseline flowsheet against which the relative impacts of the alternative sorbents will be evaluated. There are obvious advantages and potential disadvantages of selecting the Frit 202 - SB3 system. Advantages include a thorough knowledge of the sludge composition (since Click and Pareizs (2003) have reported measured compositions of the Tank 51 qualification sample). The use of Frit 202 is on firm technical ground given it was developed for "coupled operations" (i.e., HLW sludge plus high alkali from precipitate hydrolysis aqueous (PHA)) (Jantzen 1988). Although “coupled operations” is not anticipated during processing of SB3, the fact that the Tank 51 sludge was "underwashed" to provide higher sodium concentrations and anticipating the introduction of the MST or alternative sorbents from a compositional viewpoint, use of Frit 202 becomes a possible candidate.

The primary disadvantage of using this specific system is the fact that the SWPF streams being assessed may not be integrated into the DWPF process during actual processing of SB3. Therefore, one will be establishing or comparing the impacts of these secondary streams on a potentially "non-representative" sludge batch. However, consideration of other baseline flowsheets has potential issues about their use as well. For example, assume the introduction of the SWPF stream was known or projected to occur with SB4. Although there is historical information regarding the composition of SB4, frit development efforts have not been initiated to design a frit to maximize the operational windows, to produce acceptable melt rates and waste loadings, and to ultimately optimize the waste throughput of SB4 for DWPF. Developing a frit for SB4 may be rather time consuming and would require both model-based assessments and experimental work to be performed. In addition, the frit optimized for SB4 with the SWPF stream containing MST would perhaps be different. Therefore, the Frit 202 - SB3 with MST will serve as the baseline flowsheet from which the relative impacts of introducing the alternative sorbents can be assessed.

Four primary inputs are required to assess the impact on DWPF's CPC and projected operational windows. These inputs are: (1) the SB3 sludge composition, (2) the frit composition, (3) composition(s) of the SWPF streams containing MST and alternative sorbents, and (4) the nominal process volumes in DWPF including the amount of sludge and SWPF stream to be processed in a year. The first three inputs are presented in the following subsections. Section 4.0 provides a detailed discussion of the anticipated process volumes and assumptions used to estimate the incoming SWPF stream composition to DWPF.

\subsection{SB3 Sludge Composition}

Based on the Tank 51 sample results and updated projections of when SB2 and SB3 may be combined, Lilliston and Elder provided revised compositional estimates. ${ }^{1}$ Four estimates were provided based on two targeted SB3 wash endpoints (1.23M and 1.24M Na $\left.{ }^{+}\right)$and two blending

\footnotetext{
${ }^{1}$ Personal communication with G.R. Lilliston. It is noted that SB2 and SB3 were blended in the late March 2004 timeframe with the blend referred to as SB3. Initial assessments of projected operating windows for the "sludge-only system refers to the sludge as SB2/3. A review of the initial DWPF SRAT/SME products suggests no significant difference as compared to the compositional projections by Elder.
} 
options in terms of timing (175 and 200 canisters). The elemental concentrations provided were converted to an oxide basis (by multiplying by the appropriate gravimetric factor) and these data are presented in Table 3-1. A review of the projected compositions suggests very little (if any) practical difference among the four sludge compositions. Assessments by Peeler and Edwards (2003) indicate that the projected operating windows (at the Measurement Acceptability Region (MAR)) for each of these SB3 streams when coupled with Frit 202 (the nominal SB3 frit) are essentially the same. More specifically, waste loadings of approximately $27-38 \%$ result in acceptable processing and product performance predictions for each sludge composition without considering or anticipation of the compositional impact of the MST baseline or alternative sorbent streams. Therefore, to select a base sludge for blending with the SWPF streams, the authors chose the 1.23M, 175-canister option as shown (and shaded) in Table 3-1.

It should be noted that anions were not reported as part of the calcined elemental concentrations only as part of the supernate information. Therefore no assessment of the potential to exceed the anion solubility limits could be made as a function of WL for the Frit 202 - SB3 system.

Table 3-1. Projected SB2/SB3 Compositions (oxide basis, wt\%).

\begin{tabular}{|c|c|c|c|c|}
\hline Oxide & $\begin{array}{c}\text { SB3 } \\
1.23 M \\
175 \text { cans }\end{array}$ & $\begin{array}{c}\text { SB3 } \\
1.24 \mathrm{M} \\
175 \text { cans }\end{array}$ & $\begin{array}{c}\text { SB3 } \\
1.23 M \\
200 \text { cans }\end{array}$ & $\begin{array}{c}\text { SB3 } \\
1.24 M \\
200 \text { cans }\end{array}$ \\
\hline $\mathrm{Al}_{2} \mathrm{O}_{3}$ & 15.33 & 15.33 & 15.41 & 15.40 \\
\hline $\mathrm{BaO}$ & 0.15 & 0.15 & 0.15 & 0.15 \\
\hline $\mathrm{CaO}$ & 2.95 & 2.95 & 2.93 & 2.93 \\
\hline $\mathrm{Ce}_{2} \mathrm{O}_{3}$ & 0.24 & 0.24 & 0.24 & 0.24 \\
\hline $\mathrm{Cr}_{2} \mathrm{O}_{3}$ & 0.25 & 0.25 & 0.24 & 0.24 \\
\hline $\mathrm{CuO}$ & 0.08 & 0.08 & 0.08 & 0.08 \\
\hline $\mathrm{Fe}_{2} \mathrm{O}_{3}$ & 32.54 & 32.53 & 32.41 & 32.39 \\
\hline $\mathrm{K}_{2} \mathrm{O}$ & 0.94 & 0.94 & 0.96 & 0.96 \\
\hline $\mathrm{La}_{2} \mathrm{O}_{3}$ & 0.12 & 0.12 & 0.12 & 0.12 \\
\hline $\mathrm{MgO}$ & 3.57 & 3.56 & 3.57 & 3.57 \\
\hline $\mathrm{MnO}$ & 6.66 & 6.66 & 6.73 & 6.73 \\
\hline $\mathrm{Na}_{2} \mathrm{O}$ & 21.32 & 21.36 & 21.28 & 21.33 \\
\hline $\mathrm{NiO}$ & 1.82 & 1.82 & 1.83 & 1.83 \\
\hline $\mathrm{PbO}$ & 0.15 & 0.15 & 0.14 & 0.14 \\
\hline $\mathrm{SiO}_{2}$ & 2.84 & 2.84 & 2.88 & 2.88 \\
\hline $\mathrm{ThO}_{2}$ & 0.03 & 0.03 & 0.03 & 0.03 \\
\hline $\mathrm{TiO}_{2}$ & 0.03 & 0.03 & 0.03 & 0.03 \\
\hline $\mathrm{U}_{3} \mathrm{O}_{8}$ & 10.26 & 10.25 & 10.29 & 10.28 \\
\hline $\mathrm{ZnO}$ & 0.16 & 0.16 & 0.15 & 0.15 \\
\hline $\mathrm{ZrO}_{2}$ & 0.26 & 0.26 & 0.24 & 0.24 \\
\hline Total & 99.68 & 99.68 & 99.69 & 99.69 \\
\hline
\end{tabular}

\subsection{Frit Composition}

The nominal Frit 202 composition (with the acceptable tolerance values) is shown in Table 3-2. It should be noted that the nominal values (with no variation) shown in Table 3-2 were used in the 
assessments. Based on previous glass formulation experience, the introduction of most, if not all, of alternative sorbents into the Frit 202 - SB3 systems should have a positive impact of the projected operating windows.

Although Frit 202 is used it should not be considered an optimized frit for any of the systems being assessed. Its use in this report is strictly for demonstrating the impact of the alternative sorbents relative to the baseline flowsheet. If negative impacts to the projected operating window result with Frit 202, there is a high probability that strategic glass formulation efforts (via designed frits with an integrated systems approach in mind) could mitigate these impacts and restore the projected operating windows. However, Frit 202 was developed for "coupled operations" and has been shown to be effective in providing relatively large operating windows for high alkali sludges.

Assessments of melt rate for the Frit 202 - SB3 system have not been performed. Prior to implementation of any frit into DWPF, laboratory assessments of melt rate should be made to ensure that what appears attractive on paper (projected operating windows based on model predictions) does not result in a difficult feed to process.

Table 3-2. Nominal Composition (with acceptable tolerance ranges) of Frit 202.

\begin{tabular}{||c|c|}
\hline Oxide & wt \% \\
\hline $\mathrm{B}_{2} \mathrm{O}_{3}$ & $8 \pm 0.5$ \\
\hline $\mathrm{Li}_{2} \mathrm{O}$ & $7 \pm 0.5$ \\
\hline $\mathrm{Na}_{2} \mathrm{O}$ & $6 \pm 0.5$ \\
\hline $\mathrm{SiO}_{2}$ & $77 \pm 1.0$ \\
\hline $\mathrm{MgO}$ & $2 \pm 0.25$ \\
\hline & \\
\hline Total & 100 \\
\hline
\end{tabular}

\subsection{Alternative Sorbent Compositions/Cases}

Table 3-3 summarizes the nominal compositions of the MST, (which is also the Optimized MST composition), Engineered MST Case A, Engineered MST Case B, and IS-MIO sorbents. The option known as Optimized MST uses the same MST material as the baseline MST process, and, therefore, the composition given in Table 3-3, represents the sorbent material for both cases. Table 3-3 also provides the nominal composition of the 1.23M, 175-canister SB3 blend (see Table 3-1), which serves as the common sludge composition for all of the assessments. A brief description of each sorbent is provided below.

\subsubsection{MST}

MST, $\mathrm{NaTi}_{2} \mathrm{O}_{5} \mathrm{H}$, is the baseline material for Sr/actinide removal for the SRS SWPF and Actinide Removal Process (ARP) facilities. MST is an inorganic sorbent originally discovered by researchers at Sandia National Laboratory. SRTC researchers modified the synthesis of the MST to provide a material for use at SRS in the In-Tank Precipitation (ITP) process. SRTC transferred the synthesis technology to several vendors. The MST sorbent is comprised of $\mathrm{TiO}_{2}$ and $\mathrm{Na}_{2} \mathrm{O}$ and contains roughly $4.5 \mathrm{wt} \%$ bound water. 
Table 3-3. Nominal Compositions of MST and the Alternative Sorbents.

(oxide wt \%, calcined basis).

\begin{tabular}{|c|c|c|c|c|c|}
\hline Oxide & $\begin{array}{c}\text { 1.23M, 175-canister } \\
\text { option for SB3 }\end{array}$ & $\begin{array}{l}\text { MST Stream* } \\
\text { (wt\% in solids) }\end{array}$ & $\begin{array}{c}\text { Engineered } \\
\text { MST Case A } \\
\text { (wt\% in solids) }\end{array}$ & $\begin{array}{c}\text { Engineered } \\
\text { MST Case B } \\
\text { (wt\% in solids) }\end{array}$ & $\begin{array}{c}\text { IS-MIO } \\
\text { (wt \% in solids) }\end{array}$ \\
\hline $\mathrm{Al}_{2} \mathrm{O}_{3}$ & 15.33 & - & - & 90.22 & - \\
\hline $\mathrm{BaO}$ & 0.15 & - & - & - & - \\
\hline $\mathrm{CaO}$ & 2.95 & - & 0.52 & 0.29 & - \\
\hline $\mathrm{Ce}_{2} \mathrm{O}_{3}$ & 0.24 & - & - & - & - \\
\hline $\mathrm{Cr}_{2} \mathrm{O}_{3}$ & 0.25 & - & - & - & - \\
\hline $\mathrm{CuO}$ & 0.08 & - & - & - & - \\
\hline $\mathrm{Fe}_{2} \mathrm{O}_{3}$ & 32.54 & - & 0.10 & 0.09 & 49.47 \\
\hline $\mathrm{FeO}$ & - & - & - & - & 43.94 \\
\hline $\mathrm{K}_{2} \mathrm{O}$ & 0.94 & - & - & - & - \\
\hline $\mathrm{La}_{2} \mathrm{O}_{3}$ & 0.12 & - & - & - & - \\
\hline $\mathrm{MgO}$ & 3.57 & - & - & - & - \\
\hline $\mathrm{MnO}$ & 6.66 & - & - & - & - \\
\hline $\mathrm{Na}_{2} \mathrm{O}$ & 21.32 & 16.24 & - & - & - \\
\hline $\mathrm{NiO}$ & 1.82 & - & - & - & - \\
\hline $\mathrm{PbO}$ & 0.15 & - & - & - & - \\
\hline $\mathrm{SiO}_{2}$ & 2.84 & - & 0.66 & 0.2 & - \\
\hline $\mathrm{SO}_{4}{ }^{2-}$ & - & - & - & - & 6.6 \\
\hline $\mathrm{ThO}_{2}$ & 0.03 & - & - & - & - \\
\hline $\mathrm{TiO}_{2}$ & 0.03 & 83.76 & 98.72 & 9.2 & - \\
\hline $\mathrm{U}_{3} \mathrm{O}_{8}$ & 10.26 & - & - & - & - \\
\hline $\mathrm{ZnO}$ & 0.16 & - & - & - & - \\
\hline $\mathrm{ZrO}_{2}$ & 0.26 & - & - & - & - \\
\hline Totals & 99.68 & 100.0 & 100.0 & 100.0 & 100.0 \\
\hline
\end{tabular}

*MST-baseline and Optimized MST both have the same chemical composition.

\subsubsection{Optimized MST}

As previously mentioned, the Optimized MST sorbent is assumed to have an identical composition to the MST-baseline sorbent. The optimized MST sorbent is prepared by the modified synthesis to that used for the baseline MST sorbent. The modification results in a material that exhibits higher capacity and removal kinetics for strontium and actinides. The increased capacity allows the use of less material in pretreatment operations to accomplish the same degree of radionuclide separation.

\subsubsection{Engineered MST - Case A}

The Engineered MST Case A sorbent, manufactured at Oak Ridge National Laboratory (ORNL) using an internal gelation process (Collins 1998), is enriched in $\mathrm{TiO}_{2}$ with minor concentrations of $\mathrm{CaO}, \mathrm{Fe}_{2} \mathrm{O}_{3}$, and $\mathrm{SiO}_{2}$. The internal gelation process provides a unique method for the 
preparation of composite microspheres in which the MST powder can be homogeneously dispersed. Collins (1998) indicates that variations in several process parameters can control the type and shape of the hydrous metal oxide gel-spheres. The process provides a unique means to make inorganic ion exchangers more usual as an engineered form. This material contains roughly $40 \%$ bound water.

\subsubsection{Engineered MST - Case B}

$\mathrm{Al}_{2} \mathrm{O}_{3}$ is the dominant oxide for the Engineered MST Case B sorbent as made in laboratory amounts at SRTC, using internal hydrolysis. The material is produced by precipitating MST into the pores of an inorganic porous substrate. Variations on the process have been tested using other substrates in the past (Bray and Hara (1991) and Schulz (1980)). The substrate chosen for current work was Dynocel 600(tm) particles. ${ }^{2}$ These alumina particles were provided at the desired $30 \mathrm{x}$ 60 mesh. Locally they were soaked in an anhydrous alcohol solution containing tetraisopropyl titanate and sodium methoxide. MST was then precipitated by exposing the particles to a wateralcohol solution. Excess MST forming outside of the particles was washed away. MST content in the alumina was 10 to 13 weight percent on a dry basis. The product contained trace levels of $\mathrm{CaO}, \mathrm{Fe}_{2} \mathrm{O}_{3}$, and $\mathrm{SiO}_{2}$ in addition to the alumina and MST. This material contains roughly 14 wt $\%$ bound water.

\subsubsection{IS-MIO}

Testing completed by Argonne National Laboratory using SRS waste simulants showed that the IS-MIO process could be a viable alternative to MST with regards to sorption kinetics and actinide/fission product DF (Arafat et al., 2002). In previous IS-MIO development work, iron (II) was added as a sulfate salt and iron (III) was added as a nitrate salt. Sulfate is known to have a limited solubility in glass (typically $<1 \mathrm{wt} \% \mathrm{SO}_{4}{ }^{2-}$ ), and although iron (II) could be added with an alternative counter anion (e.g., $\mathrm{Cl}^{-}$), sulfate was assessed to be added to the process stream as a result of the IS-MIO process for this evaluation. The nominal IS-MIO sorbent additive that remains in the DWPF feed stream (i.e., the material that is not removed during the SWPF alpha strike processing steps) consists of mixed iron oxides, sulfate, and nitrate. Nitrate is roughly equivalent to $7.9 \%$ of the IS-MIO material that is transferred to DWPF.

\footnotetext{
${ }^{2}$ Dynocel 600(tm) particles are produced by Porocel Corp., Little Rock, AR.
} 
WSRC-TR-2004-00200

Revision 0

\subsection{MATERIAL BALANCE BLENDING STRATEGIES AND ASSUMPTIONS}

The SWPF will generate two streams to be transferred to the DWPF. One stream will primarily contain the sorbent material, which is used to remove actinides and strontium from salt solutions. This stream is concentrated to increase solids content and also contains entrained sludge solids. It is washed to remove sodium salts before it is transferred to the DWPF. The second stream is generated during caustic side solvent extraction in the SWPF. The stream that is transferred to DWPF is slightly acidic and contains concentrated Cs.

Since the process flowsheet and associated material balances have not been finalized for the SWPF, official guidance from project management ${ }^{3}$ was used to generate potential SWPF flow rates and stream compositions. In all cases, it was assumed that the SWPF would achieve a nominal annual throughput of 3 million gallons of waste at $6.44 \mathrm{M} \mathrm{Na}$. The facility was also assumed to operate at 75\% utility, while DWPF operations were assumed to be limited by melter life. For the material balances, a melter (and DWPF) was assumed to operate for 24 months before requiring a 6 month replacement outage. Therefore the DWPF outage cycle time was 30 months. It was also assumed that the SWPF has a storage capacity for 1 week's worth of production. Given these assumptions, the design throughput bases (for SWPF and DWPF) are $4.948 \mathrm{Mgal} / \mathrm{yr}$ (3Mgal/yr $\div 75 \%$ availability x DPWF outage cycle time / [DWPF operating period + SWPF storage capacity]) of liquid waste at $6.44 \mathrm{M} \mathrm{Na}$. This allows the SWPF to meet higher attainment if the SWPF availability is greater or if the DWPF melter does not have to be replaced as rapidly.

Two different MST concentrations have been proposed for SWPF processing. These are 0.4 and $0.8 \mathrm{~g} / \mathrm{l}$. For this evaluation, the DWPF feed stream was assumed to contain $80 \%$ of feed from processing at $0.4 \mathrm{~g} / \mathrm{l}$ and $20 \%$ of feed from processing at $0.8 \mathrm{~g} / \mathrm{l}$. This guidance was provided in Painter (2003) and Edwards (2003).

Based on the guidance provided, concentrations of the materials in the alpha strike process liquid and solid streams and in the concentrated Cs stream were estimated. The composition estimates

are given in Table 4-1. Baseline volume flow rates were also calculated for the three streams and are shown in Table 4-2.

\footnotetext{
${ }^{3}$ Guidance provided by S.D. Fink via email on April 8, 2004.
} 
WSRC-TR-2004-00200

Revision 0

Table 4-1. Composition of SWPF Streams to Be Transferred to DWPF

\begin{tabular}{|c|c|c|c|c|c|}
\hline \multicolumn{4}{|c|}{$\begin{array}{c}\text { Alpha Strike Process } \\
\end{array}$} & \multirow{2}{*}{\multicolumn{2}{|c|}{ Concentrated Cs Stream }} \\
\hline \multicolumn{2}{|c|}{ Liquid Stream } & \multicolumn{2}{|c|}{ Solid Stream } & & \\
\hline Component & g/l & Component & g/l & Component & g/l \\
\hline $\mathrm{Al}(\mathrm{OH})_{4}$ & 5.58 & sludge solids & 32.5 & $\mathrm{NO}_{3}$ & 0.460 \\
\hline $\mathrm{CO}_{3}$ & 0.362 & MST & 30.3 & Cs & 0.853 \\
\hline $\mathrm{NO}_{2}$ & 1.44 & & & Extractant & 0.000402 \\
\hline $\mathrm{NO}_{3}$ & 5.03 & & & Modifier & 0.0127 \\
\hline $\mathrm{OH}$ & 5.08 & & & TOA & 0.0000531 \\
\hline $\mathrm{PO}_{4}$ & 0.339 & & & & \\
\hline $\mathrm{SO}_{4}{ }^{2-}$ & 0.471 & & & & \\
\hline $\mathrm{Cs}$ & 0.00508 & & & & \\
\hline $\mathrm{Cu}$ & 0.0121 & & & & \\
\hline $\mathrm{Hg}$ & 0.00410 & & & & \\
\hline $\mathrm{K}$ & 0.0959 & & & & \\
\hline $\mathrm{Na}$ & 11.5 & & & & \\
\hline
\end{tabular}

Table 4-2. Baseline MST SWPF Process Flow Rates to DWPF

\begin{tabular}{||c|c||}
\hline Process Stream & Volume Flow (gal/yr) \\
\hline Alpha Strike - Liquid Stream & 8.92 E04 \\
\hline Alpha Strike - Solid Stream & 4.17 E03 \\
\hline Concentrated Cs Stream & 3.95 E05 \\
\hline
\end{tabular}

The values in Table 4-2 were used to estimate the projected MST use per year in the SWPF actinide removal process. Projections for the annual use of the other sorbents were made using the baseline MST value and the known or estimated performance of the other sorbent options. Table 4-3 contains these projections.

Table 4-3. Sorbent Compositions Projected Annual Use

\begin{tabular}{||c|c||}
\hline Sorbent Type & Sorbent Use (kg/yr) \\
\hline MST & 1.07 E04 \\
\hline Optimized MST & 2.73 E03 \\
\hline Engineered MST Case A & 8.20 E03 \\
\hline Engineered MST Case B & 4.10 E04 \\
\hline IS-MIO & 6.53 E03 \\
\hline
\end{tabular}

For the Optimized MST case, it was assumed that improvements in performance could be made such that only $\sim 25 \%$ of the MST sorbent material would be used in a year. Thus, the number in Table 4-3 for Optimized MST represents 25\% of the requirement for the baseline MST. The volumes of the liquid stream and the sludge solids associated with the actinide removal part of the 
SWPF facility were assumed to remain constant for the Optimized MST case. Therefore, the only value from Table 4-2 that was adjusted was the "Alpha Strike - Solid Stream" (i.e., the sorbent and sludge solids), which was reduced to $2.30 \mathrm{E} 03$ gal/yr. [Stated another way, no credit was assumed for improved batching strategy possible with use of less sorbent nor was credit taken for less frequent chemical cleaning of the filters as likely will occur with lower solids content.] The fresh waste number was estimated based on maintaining the throughput for the fresh waste containing the entrained sludge. This throughput was added to the adjusted throughput for the alternative sorbent stream. For the Optimized MST case, as well as all of the other cases, the throughput of the "MST" portion or sorbent portion of the "Alpha Strike - Solids Stream" was scaled to the associated increase or reduction in the amount of sorbent used per year (see Table 4-3). As an example, the Optimized MST case reduces the sorbent utilized per year by $\sim 75 \%$; therefore, the throughput of the sorbent portion of the stream was reduced by $\sim 75 \%$ (i.e., $6.42 \mathrm{E} 02 \mathrm{gal} / \mathrm{yr}$ ) and was added to the fresh waste throughput (i.e., $1.66 \mathrm{E} 02 \mathrm{gal} / \mathrm{yr}$ ). Once again, this calculation was performed for each of the cases.

The two Engineered MST cases both use a different type of sorbent than the baseline process. They also rely on a packed column for performing the actinide removal as opposed to the baseline cross-flow filtration process. Due to this arrangement and the associated lower solids content, chemical cleaning of the filters in the SWPF will occur less frequently. However, since flush water is needed to sluice the Engineered MST from the column into the DWPF transfer stream, the assumption was made that this extra water is equal to or less than the water saved by reducing chemical cleaning frequency. This assumption also implies that the materials can be transferred at the resulting solids level and will not require further adjustment. Cycle time saved from cleaning is assumed to be balanced by the cycle time needed for column operations. Since the salt waste to be treated contains much higher quantities of uranium than plutonium, the column loading was assumed to be limited by uranium sorption. Assuming the waste (dilute 5.6 M Na waste) contains $10 \mathrm{mg} / \mathrm{l} \mathrm{U}$, then the projected usage would be $4.1 \mathrm{E} 03 \mathrm{~kg} / \mathrm{yr}$ for MST material (Hobbs 2002). However, the Engineered MST materials do not have the same compositions or performance as the baseline MST sorbent. For Case A, the ORNL material is $50 \mathrm{wt} \% \mathrm{MST}$, so projections are that twice the mass of material (compared to the baseline MST) will have to be used per year in SWPF operations. This resulted in a change in the "Alpha Strike - Solid Stream" flow to 3.58 E03 gal/yr. Case B material assumes only $10 \mathrm{wt} \%$ MST loading, so a significantly larger fraction of material is necessary compared to the baseline MST process. The associated “Alpha Strike - Solid Stream” flow rate estimate was 1.13 E04 gal/yr.

Finally, the IS-MIO case was approached slightly differently than the other streams since it is not a sorbent but is instead chemical additives. For each gram of MST in the baseline MST material balance, it was assumed that $0.500 \mathrm{~g} \mathrm{Fe}, 0.645 \mathrm{~g} \mathrm{SO}_{4}{ }^{2-}$, and $0.833 \mathrm{~g} \mathrm{NO}_{3}$ would be needed to perform the necessary radiochemical separation (Pereira et al 2004). However, most of the sulfate and nitrate added remain soluble and are not carried forward to DWPF because of the washing performed in the SWPF. The estimated dilution factor for soluble species is $~ 13.4$, which results in only $0.500 \mathrm{~g} \mathrm{Fe}, 0.048 \mathrm{~g} \mathrm{SO}_{4}{ }^{2-}$, and $0.062 \mathrm{~g} \mathrm{NO}_{3}$ being transferred to DWPF with the actinide removal portion of the stream. This results in an "Alpha Strike - Solid Stream" flow rate of $3.19 \mathrm{E} 03 \mathrm{gal} / \mathrm{yr}$. 
The information presented above, as well as compositional information provided in Table 3-3 and Table 4-1, was used to estimate the DWPF Sludge Receipt and Adjustment Tank (SRAT) receipt or feed stream compositions. The information was also used to estimate the total volume of material to be received at DWPF for each case. The assumption was then made that DWPF would process the material in 45 CPC batches per year. Currently, the DWPF is processing a CPC batch per week (excluding instances for outages), so this should be a reasonable assumption. It should also be conservative from a CPC processing and glass composition perspective, since a greater number of CPC batches per year would dilute the effects of the SWPF feed stream. Table 4-4 provides the projected annual quantity of material and estimated volume per CPC batch for each sorbent. Very little difference was seen among the five different options with respect to volume to be processed at DWPF. Once again, changes in the volume of the Alpha Strike stream do occur with sorbent changes, but the total SWPF volume changes are negligible when compared to the large volume associated with the concentrated Cs stream.

Table 4-4. Estimated Volume of SWPF Stream to Be Processed in DWPF

\begin{tabular}{||c|c|c||}
\hline Sorbent & Volume (gal/yr) & Volume (gal/batch) \\
\hline Baseline MST & $4.89 \mathrm{E} 05$ & $1.09 \mathrm{E} 04$ \\
\hline Optimized MST & $4.87 \mathrm{E} 05$ & $1.08 \mathrm{E} 04$ \\
\hline Engineered MST Case A & $4.88 \mathrm{E} 05$ & $1.08 \mathrm{E} 04$ \\
\hline Engineered MST Case B & $4.96 \mathrm{E} 05$ & $1.10 \mathrm{E} 04$ \\
\hline IS-MIO & $4.88 \mathrm{E} 05$ & $1.08 \mathrm{E} 04$ \\
\hline
\end{tabular}

Currently, the DWPF is operating on a sludge-only flowsheet. Coupled operations were planned for the incorporation of the Precipitate Hydrolysis Aqueous stream. However, since DWPF has become operational, the salt processing flowsheet has changed leading to revised approaches for incorporating the solids and radionuclides from the salt stream into the DWPF process. For the development of the flowsheet for DWPF processing of the ARP stream, several processing cases were considered, but the most advantageous to DWPF was to reduce the volume of the ARP stream through concentration before processing with HLW sludge. The DWPF SRAT can hold 11,000 gallons; however, its nominal operating volume is 6,000 gallons with a maximum operating volume of $\sim 7,000$ gallons. For the ARP process, all of the liquid associated with the ARP stream was evaporated to accommodate a full 6,000 gallon sludge batch (Baich et al. (2003). Therefore, in this study, the assumption was made that DWPF would boil off the volume of each input stream before commencing SRAT processing with the nominal 6,000 gallons of sludge.

The assumptions identified above were used to estimate SRAT sludge compositions for each case. The contributions to each estimated SRAT composition include the base sludge (SB3) and the SWPF stream including the sorbent solids, entrained sludge solids from SWPF (assumed to be the same composition as the SB3 sludge), liquid portion of the actinide and Sr removal stream (alpha strike process), and concentrated Cs stream. Table 4-5 provides the estimated total solids, Na molarity, and volume for the baseline sludge and each of the SWPF stream cases. All of the properties for the SWPF streams include the contribution from the Alpha Strike Process streams and the concentrated Cs Streams. Table 4-6 summarizes the estimated SRAT sludge compositions for each of the cases. 
Table 4-5. Estimated Properties of Baseline Sludge and SWPF Streams.

\begin{tabular}{||c|c|c|c||}
\hline STREAM & $\begin{array}{c}\text { TOTAL } \\
\text { SOLIDS }\end{array}$ & NA (M) & $\begin{array}{c}\text { VOLUME } \\
\text { (GAL) }\end{array}$ \\
\hline SB3 Sludge & $23.9 \%$ & 1.45 & $6.00 \mathrm{E} 03$ \\
\hline MST & $1.81 \%$ & 0.151 & $4.15 \mathrm{E} 04$ \\
\hline Optimized MST & $1.41 \%$ & 0.130 & $4.13 \mathrm{E} 04$ \\
\hline Engineered Case A & $1.53 \%$ & 0.122 & $4.14 \mathrm{E} 04$ \\
\hline Engineered Case B & $3.10 \%$ & 0.121 & $4.22 \mathrm{E} 04$ \\
\hline IS-MIO & $1.61 \%$ & 0.149 & $4.14 \mathrm{E} 04$ \\
\hline
\end{tabular}

Table 4-6. Resulting SRAT Products for the MST and Alternative Sorbents.

(wt\% calcined oxide basis)

\begin{tabular}{||c|c|c|c|c|c||}
\hline \hline Oxide & MST & $\begin{array}{c}\text { Optimized } \\
\text { MST }\end{array}$ & $\begin{array}{c}\text { Engineered } \\
\text { MST Case A }\end{array}$ & $\begin{array}{c}\text { Engineered } \\
\text { MST Case B }\end{array}$ & IS-MIO \\
\hline $\mathrm{Al}_{2} \mathrm{O}_{3}$ & 14.6 & 15.1 & 15.0 & 25.2 & 14.9 \\
\hline $\mathrm{BaO}$ & 0.138 & 0.143 & 0.141 & 0.125 & 0.141 \\
\hline $\mathrm{CaO}$ & 2.73 & 2.82 & 2.81 & 2.52 & 2.79 \\
\hline $\mathrm{Ce}_{2} \mathrm{O}_{3}$ & 0.223 & 0.230 & 0.228 & 0.202 & 0.227 \\
\hline $\mathrm{Cr}_{2} \mathrm{O}_{3}$ & 0.227 & 0.235 & 0.232 & 0.206 & 0.232 \\
\hline $\mathrm{Cs}_{2} \mathrm{O}$ & 0.563 & 0.581 & 0.575 & 0.510 & 0.574 \\
\hline $\mathrm{CuO}$ & 0.0782 & 0.0808 & 0.0800 & 0.0708 & 0.0797 \\
\hline $\mathrm{Fe}_{2} \mathrm{O}_{3}$ & 30.2 & 31.2 & 30.9 & 27.4 & 32.0 \\
\hline $\mathrm{FeO}$ & 0.00 & 0.00 & 0.00 & 0.00 & 1.03 \\
\hline $\mathrm{K}_{2} \mathrm{O}$ & 0.886 & 0.915 & 0.907 & 0.803 & 0.904 \\
\hline $\mathrm{La}_{2} \mathrm{O}_{3}$ & 0.114 & 0.118 & 0.117 & 0.103 & 0.116 \\
\hline $\mathrm{MgO} \mathrm{O}$ & 3.31 & 3.42 & 3.38 & 3.00 & 3.37 \\
\hline $\mathrm{MnO} \mathrm{O}$ & 6.18 & 6.38 & 6.32 & 5.60 & 6.30 \\
\hline $\mathrm{Na}_{2} \mathrm{O}$ & 22.6 & 22.8 & 22.4 & 19.9 & 22.4 \\
\hline $\mathrm{NiO} \mathrm{N}_{2}$ & 1.69 & 1.74 & 1.73 & 1.53 & 1.72 \\
\hline $\mathrm{P}_{2} \mathrm{O}_{5}$ & 0.0355 & 0.0367 & 0.0363 & 0.0322 & 0.0362 \\
\hline $\mathrm{PbO}^{2}$ & 0.135 & 0.139 & 0.138 & 0.122 & 0.137 \\
\hline $\mathrm{SO}_{4}{ }^{2-}$ & 0.0660 & 0.0681 & 0.0675 & 0.0598 & 0.222 \\
\hline $\mathrm{SiO}_{2}$ & 2.64 & 2.72 & 2.71 & 2.41 & 2.69 \\
\hline $\mathrm{ThO}_{2}$ & 0.0315 & 0.0326 & 0.0323 & 0.0286 & 0.0322 \\
\hline $\mathrm{TiO}_{2}$ & 3.58 & 0.960 & 2.07 & 1.24 & 0.0237 \\
\hline $\mathrm{U}_{3} \mathrm{O}_{8}$ & 9.52 & 9.83 & 9.73 & 8.62 & 9.70 \\
\hline $\mathrm{ZnO}$ & 0.145 & 0.149 & 0.148 & 0.131 & 0.148 \\
\hline $\mathrm{ZrO}_{2}$ & 0.239 & 0.247 & 0.245 & 0.217 & 0.244 \\
\hline & & & & & \\
\hline $\mathrm{Total}$ & 100.0 & 100.0 & 100.0 & 100.0 & 100.0 \\
\hline \hline
\end{tabular}


WSRC-TR-2004-00200

Revision 0

\subsection{IMPACTS TO CPC PROCESSING}

The main objectives of the CPC stage in the DWPF are the destruction of nitrite, reduction of $\mathrm{Hg}$ and $\mathrm{Mn}$, neutralization of the base equivalents in the sludge, and adjustment of the slurry rheology to facilitate processing in the DWPF melter. Currently, the DWPF calculates the amount of acid to be added to each CPC SRAT batch based on the composition of the material received in the SRAT process vessel. The applicability of the acid addition equation to include ARP process streams that include MST and sludge solids has already been demonstrated (Baich et al. 2003).

For each of the cases in this evaluation, the acid demand of the SWPF sorbent stream was individually estimated and then the acid demand of the combined sludge and SWPF sorbent stream was estimated. To determine the associated mass of the process volumes identified in Table 4-4, densities of the adjusted sorbent streams were necessary. This information was not readily available for each of the streams, so an estimate for density was made for each case. In the baseline MST case, the density of the MST stream (i.e., $9.59 \mathrm{lbs} / \mathrm{gal}$ ) and the density of the fresh waste part of the stream (i.e., $15 \mathrm{lbs} /$ gal) were scaled to the associated percentages of the throughput of each stream. As an example, if the fresh waste represented 55\% of the throughput, then its density contributed 55\% to the DWPF output feed stream density. This was done for each case, and the density of the sorbent stream itself was assumed to remain constant since actual densities were not available.

Since the flowsheets for processing of the sorbent materials in the SWPF and the DWPF are still being developed, several assumptions had to be made to estimate the impact parameters needed for the acid calculation. Key assumptions included the following:

- The information provided by project management and outlined in Section 4.0 was used to estimate the nitrite, hydroxide, carbonate, total solids, insoluble solids, nitrate, and density of the SWPF stream to be transferred to DWPF. Soluble solids were assumed to come only from the materials identified in Table 4-1, and the only other solids were assumed to come from the sorbent material and the entrained sludge solids. The resulting solids concentrations were assumed to meet transfer criteria, and it was assumed that no additional changes to the stream would be necessary for transfer.

- The amount of Hg and Mn in the incoming SWPF stream will depend greatly on the material being processed. For these calculations, the SB3 sludge concentrations were used in conjunction with the amount of entrained sludge solids and were assumed to be the only source of Hg and Mn.

- DWPF will reduce the volume associated with the SWPF streams through boiling/concentration before processing and the starting volume will be roughly equivalent to that currently being used in DWPF ( 6,000 gallons). The volume to be removed should be adjusted for the solids remaining in the vessel.

- The input parameters for the acid calculation were based on the individual inputs of the sludge and SWPF streams. This assumes no loss during boiling. Based on earlier DWPF flowsheet testing, this is a reasonable approach and was found to be conservative for the ARP flowsheet cases (Baich et al. 2003).

- The density of the SRAT receipt material is a necessary input parameter and this was estimated by assuming that the mass of solids from the SWPF stream and the sludge solids remained in a $\sim 6,000$ gallon batch. 
- The SWPF introduces organics as part of the concentrated Cs stream. The assumption was made that all organics transferred to the DWPF were accounted for in the material balance information provided by project management. In calculating the REDOX term of the acid calculation, it was assumed that the total quantity of material was present as carbon. This should be conservative since it is a greater amount of carbon than would actually be present, and, thus, a lower level should not present a processing issue.

- The IS-MIO stream introduces a small amount of reduced iron $\left(\mathrm{Fe}^{+2}\right)$. For evaluation purposes, it was assumed that the proper REDOX control could be obtained in the melter feed by adjusting the formic to nitric ratio. Since the amount of reduced iron is small, this should be a valid assumption.

In order to use the existing DWPF acid addition equation, the inputs have to be measured on the SRAT slurry as is currently performed in the DWPF. Based on the ARP flowsheet studies, minimal impact on the SRAT slurry receipt analysis is anticipated for the MST sorbent material. The other sorbent materials should also not present an analytical issue. However, the ability to analyze the materials in a sludge stream should be demonstrated before being introduced in the DWPF. Particularly, any component present at $>0.5 \mathrm{wt} \%$ in the glass has to be reported to meet Waste Acceptance Product Specifications.

For the four alternatives, no significant variation was seen in the acid demand of the individual SWPF sorbent streams. This is because no substantial differences in the feed stream compositions were assumed other than the sorbent itself. Some differences were seen in the calculated values for the total and insoluble solids associated with each sorbent stream, which also affected the organics, Hg and Mn input parameters. However, the overall impact to the acid addition requirement was minimal. Also, the acid demand for the four alternatives was equivalent to the acid demand of the baseline MST SWPF stream.

Table 5-1provides the inputs for the acid calculation in each of the cases when combined with nominal 6,000 gallons of sludge. Although the inputs change slightly for each case, the overall acid demand remained constant, as did the relative concentration of formic to nitric acid. Therefore, no impacts on acid demand are anticipated for any of the options relative to the baseline MST process.

Due to the presence of a small quantity of reduced iron in the IS-MIO stream, methods may have to be developed to quantify its concentration in DWPF. The existing acid addition equation and associated REDOX equation assume that all of the iron introduced into the SRAT process is oxidized; therefore, an iron term does not exist in the REDOX equation but a $\mathrm{Fe}^{2+} / \Sigma \mathrm{Fe}$ of 0.2 is targeted based on other input parameters. Studies will have to be performed to demonstrate that the contribution from the IS-MIO stream is insignificant when estimating the glass REDOX or the existing equation will have to be modified to account for its contribution. Until those studies are completed, it is not known whether the SRAT receipt analysis strategy will require modification. The IS-MIO stream is the only case that presents this problem. 
WSRC-TR-2004-00200

Revision 0

Table 5-1. Inputs for the DWPF Acid Addition Calculation.

\begin{tabular}{||l|c|c|c|c|c||}
\hline Input Parameter & MST & $\begin{array}{c}\text { Optimized } \\
\text { MST }\end{array}$ & $\begin{array}{c}\text { Engineered } \\
\text { MST Case A }\end{array}$ & $\begin{array}{c}\text { Engineered } \\
\text { MST Case B }\end{array}$ & IS-MIO \\
\hline $\begin{array}{l}\text { Sludge amount } \\
\text { (gal) }\end{array}$ & 6,000 & 6,000 & 6,000 & 6,000 & 6,000 \\
\hline $\begin{array}{l}\text { SWPF stream } \\
\text { amount (gal) }\end{array}$ & 10,858 & 10,818 & 10,847 & 11,018 & 10,838 \\
\hline $\begin{array}{l}\text { Estimated SWPF } \\
\text { density (lb/gal) }\end{array}$ & 11.7 & 13.5 & 12.1 & 10.4 & 12.4 \\
\hline $\begin{array}{l}\text { SRAT Receipt } \\
\text { Mass (kg) }\end{array}$ & 28,233 & 28,064 & 28,114 & 28,790 & 28,150 \\
\hline Nitrite (mg/kg) & 17,904 & 18,012 & 17,980 & 17,558 & 17,957 \\
\hline Hydroxide (Eq/l) & 0.544 & 0.544 & 0.544 & 0.544 & 0.544 \\
\hline $\begin{array}{l}\text { Total Inorganic } \\
\text { Carbon (mg/kg) }\end{array}$ & 1090 & 1097 & 1095 & 1069 & 1093 \\
\hline $\begin{array}{l}\text { Hg (wt\% in } \\
\text { solids) }\end{array}$ & 0.107 & 0.109 & 0.109 & 0.099 & 0.108 \\
\hline $\begin{array}{l}\text { Mn (wt\% in } \\
\text { solids) }\end{array}$ & 3.54 & 3.62 & 3.60 & 3.29 & 3.58 \\
\hline $\begin{array}{l}\text { Total Solids } \\
\text { (Wt\%) }\end{array}$ & 25.9 & 25.5 & 25.6 & 27.4 & 25.7 \\
\hline $\begin{array}{l}\text { Insoluble Solids } \\
\text { (Wt\%) }\end{array}$ & 18.0 & 17.5 & 17.6 & 19.6 & 17.7 \\
\hline Nitrate (mg/kg) & 16,186 & 16,284 & 16,254 & 15,873 & 16,638 \\
\hline Density (g/ml) & 1.24 & 1.24 & 1.24 & 1.27 & 1.24 \\
\hline Oxalate (mg/kg) & 3202 & 3222 & 3216 & 3141 & 3212 \\
\hline $\begin{array}{l}\text { Organics (wt\% in } \\
\text { solids) }\end{array}$ & 0.074 & 0.104 & 0.093 & 0.038 & 0.090 \\
\hline $\begin{array}{l}\text { Acid Demand } \\
\text { (moles/l of slurry) }\end{array}$ & 1.38 & 1.38 & 1.38 & 1.38 & 1.38 \\
\hline $\begin{array}{l}\text { Formic Acid } \\
\text { Percentage }\end{array}$ & $94 \%$ & $94 \%$ & $94 \%$ & $94 \%$ & $94 \%$ \\
\hline \hline
\end{tabular}

In addition to the acid addition strategy, the CPC must also consider the processing time associated with the additions of the various quantities and types of sorbents. Incoming sludge ( $\sim 6000$ gallons) is received in the CPC in the SRAT that contains a heel of treated sludge ( 1500 gallons) from the previous batch. Flush water ( 1500 gallons) is also transferred as part of the operations. The sludge is heated to below boiling and then nitric and formic acids are added. The vessel contents are then heated to boiling and the treated sludge is concentrated to obtain a nominal process volume of 6,000 gallons. After concentration, the contents are boiled in reflux conditions for 12 hours to complete the necessary reactions. Currently the DWPF's baseline boilup rate is 5,000 pounds (of liquid) per hour, but recently a boil-up rate of $\sim 2,500$ pounds per hour is more prototypic. A typical sludge transfer takes 10 hours in DWPF with the entire SRAT cycle taking $\sim 84$ hours ${ }^{4}$. For the volume/mass of materials associated with the different SWPF sorbent streams (see Table 4-4), the DWPF processing time would be increased 18 - 36 hours assuming a boil-up rate between the prototypic and baseline could be obtained throughout the required boiling time which seems reasonable given the relatively small increase in total solids and the

\footnotetext{
${ }^{4}$ Personal communication with P. Patel (DWPF Engineering).
} 
composition of the solids. This time does not include any additional time required for material transfers (which traditionally take 10 hours) and time needed to cool and reheat the vessel, since all of the material cannot be transferred at once due to the volume limitations of the SRAT vessel and the transfers are not performed at elevated temperatures. As stated above the entire SRAT cycle usually takes $\sim 84$ hours; therefore, the cycle time in the SRAT would easily be increased $\sim 50 \%$ with the SWPF stream incorporated. During ARP flowsheet development, the DWPF expressed the preference for performing these process steps sequentially instead of simultaneously. In other words, material would be transferred, concentration would be performed, and then additional material would be transferred or sampled depending on the stage of the process. Based on the listed assumptions, no real differences in processing time are evident between the baseline MST SWPF stream and the alternative streams.

DWPF CPC operations and melter feed processing both rely heavily on the rheological behavior of the sludge slurry. The DWPF's SB2 had significant problems with feed transfers and melter feeding. Problems in these areas can result in reduced melter production, which in turn reduces the number of canisters produced from DWPF. Therefore, any changes to the feed slurry must consider the impact on slurry rheology (e.g., slurry yield stress). Addition of a SWPF stream into the DWPF will increase the solids concentration and change the type of solids (composition and particle size) that are introduced. Based on the limited information available, the Engineered MST Case B would appear to be the feed most out of the range of existing DWPF processing. It has a total and insoluble solids content that is higher than the remaining cases. The SWPF waste streams may also change the chemical composition or $\mathrm{pH}$ of the slurry. All of these have the potential to negatively affect rheology. In addition, the rheology of the feed may change as a result of caustic boiling and concentration of the SWPF stream prior to acid addition. Caustic boiling of the slurry presents different processing issues than the current DWPF acid boiling process. In the ARP studies, caustic boiling was acceptable at solids concentrations similar to those used in the DWPF SRAT process.

To fully understand the effects of the SWPF streams on rheology, simulant studies should be performed. Included in these studies should be appropriately sized sorbent material so agglomeration effects during processing can be investigated. The studies should also provide the opportunity to test the current antifoam addition strategy, which is used to mitigate foaming in the process vessels, and acid addition strategies to assist with slurry rheological properties.

This section addressed the potential CPC processing impacts from the alternative sorbent streams and different volumes associated with these streams. Compared to the baseline MST sorbent and process, no increase in acid demand would be expected for the alternative sorbents. For the ISMIO case, additional studies would have to be performed to account for the impacts of the reduced iron on the targeted REDOX. Of greater concern are the potential impacts on process rheology, which can not be ascertained without actual testing of the sorbent materials. The Engineered MST Case B appears to present the largest challenge with respect to rheology since it contains the highest total and insoluble solids content. It also has the greatest impact on sludge composition, which may also affect the sludge rheology. 
WSRC-TR-2004-00200

Revision 0

\subsection{IMPACTS TO GLASS PROPERTIES: THE STRATEGY OR APPROACH}

Using the available Product Composition Control System (PCCS) models (Brown, Postles and Edwards (2002)), the alternative sorbents were assessed in terms of the predicted impacts and projected operating windows relative to the Frit 202 - SB3 with the baseline SWPF stream containing MST flowsheet. In this section, the approach or strategy to make such comparisons is presented. It should be noted that the assessments are solely model-based. That is, the operating windows (defined in terms of waste loadings over which acceptable glasses can be made) will be projected using compositional-property models that are currently defined in PCCS. No experimental work was performed as a part of this assessment.

Two stages of investigation have been proposed by Peeler and Edwards (2002) to assess various frit/sludge combinations: the Nominal Stage and the Variation Stage. In this study, the Nominal Stage utilizes nominal compositions representing the combination of Frit 202 and the various SRAT products resulting from the introduction of the MST baseline or alternative sorbent streams into the SB3 flowsheet. In general, this stage is used to provide or project the operational windows (in terms of waste loadings allowed) for the nominal compositions considered. It is important to note that during this stage, composition variation in the sludge is not accounted for strictly nominal compositions are considered. Assessments are made using predictions from models currently implemented in the DWPF over the waste loading (WL) interval of interest (25 $-60 \mathrm{wt} \%)$. The primary property predictions assessed include those for liquidus temperature $\left(T_{L}\right)$, viscosity $(\eta)$, durability (e.g., normalized boron release $\left.-\mathrm{NL}[\mathrm{B}]\right)$, the constraints associated with durability $\left(\mathrm{Al}_{2} \mathrm{O}_{3}\right.$ and sum of alkali), and specific solubility limits (e.g., $\mathrm{SO}_{4}{ }^{2-}$ and $\left.\mathrm{TiO}_{2}\right)$. It should be noted that the projected operating windows did not account for potential canister dose rates that could exceed acceptance levels due to high concentrations of Cs.

The intent or focus of the Variation Stage (Stage 2) assessment is to gain insight into the robustness of the system with respect to compositional variation. Although an extremely valuable tool, the Variation Stage was not used for this study. All assessments were performed on nominal compositions. 


\subsection{MEASUREMENT ACCEPTABILITY REGION (MAR) LIMITS USED FOR THE ASSESSMENTS}

The glass property predictions assessed in this study included durability (Product Consistency Test [PCT] [ASTM 2002] response in terms of the preliminary glass dissolution estimator $\left(\Delta \mathrm{G}_{\mathrm{P}}\right)$ (Jantzen et al. 1995)), viscosity at $1150^{\circ} \mathrm{C}\left(\eta_{1150^{\circ} \mathrm{C}}\right), \mathrm{T}_{\mathrm{L}}$ (new model), and $\mathrm{Al}_{2} \mathrm{O}_{3}$ and alkali concentrations. Jantzen et al. (1995) and Brown et al. (2001) provide a more detailed discussion on the development of these models. To project operational windows for sludge/frit scenarios of interest, the predicted properties must be assessed relative to established acceptance criteria. Acceptable predicted properties for this assessment are based on satisfying their respective (and most restrictive) MAR limit values. Brown, Postles, and Edwards (2002) provide a detailed discussion of how the MAR limits are utilized in PCCS. It should be noted that the MAR limits are compositionally dependent for some properties (i.e., will change as a function of glass composition); thus a table can not be shown with "standard or set" values. Although the models and acceptance limits are seemingly well-defined, some interesting technical issues result with the introduction of the baseline and alternative sorbents with respect to glass chemistry and model predictions. A brief discussion of the primary compositional concerns, potential model validity issues, and changes to various acceptance criteria is provided below.

The introduction of significant quantities of $\mathrm{TiO}_{2}$ from the baseline MST, the Optimized MST, and the Engineered MST Case A sorbent cases presents interesting technical issues associated with the application of the compositional-based models and specific individual "solubility" limits within PCCS. Lorier and Jantzen (2003) have provided the technical basis for raising the current $1 \% \mathrm{TiO}_{2}$ limit in PCCS to $2 \%$. The primary driver for this technical baseline change was that introduction of these $\mathrm{TiO}_{2}$-based sorbents could result in the individual $\mathrm{TiO}_{2}$ solubility limit of $1 \%$ being exceeded; thus, waste loading would be artificially limited or significant impacts could occur to the projected operating windows. For these assessments, $\mathrm{TiO}_{2}$ concentrations up to $2 \%$ (ignoring measurement uncertainties) were allowed (i.e., were classified as acceptable based on the Slurry Mix Evaporator (SME) acceptability process). For those glasses in which the $\mathrm{TiO}_{2}$ concentrations exceed $2 \%$, issues regarding the applicability of the $\mathrm{T}_{\mathrm{L}}$ model surface as noted by Lorier and Jantzen (2003).

The Engineered MST Case B sorbent results in relatively high $\mathrm{Al}_{2} \mathrm{O}_{3}$ concentrations in glass (approximately $6.3-15.1 \mathrm{wt} \%$ over the $25-60 \% \mathrm{WL}$ interval based on the SRAT product shown in Table 3-3. The development of the "new” DWPF $\mathrm{T}_{\mathrm{L}}$ model (Brown et al. (2001)) covered a compositional range of $\mathrm{Al}_{2} \mathrm{O}_{3}$ concentrations of 0.99 to $14.162 \mathrm{wt} \%$. Although the resulting $\mathrm{Al}_{2} \mathrm{O}_{3}$ concentrations for glasses based on the Engineered MST Case B option exceed the upper range over which the model was developed, the application of the model is valid over most of the WL interval. Although risk exists for using the $\mathrm{T}_{\mathrm{L}}$ model to assess glasses whose $\mathrm{Al}_{2} \mathrm{O}_{3}$ concentrations exceed the $14.162 \mathrm{wt} \%$ limit, it is minimal for this extrapolation given other properties are limiting at these higher WLs.

For the IS-MIO based glasses, introduction of reduced and oxidized $\mathrm{Fe}\left(\mathrm{FeO}\right.$ and $\mathrm{Fe}_{2} \mathrm{O}_{3}$ ) as well as $\mathrm{SO}_{4}{ }^{2-}$ into the flowsheet poses some interesting technical issues and solubility concerns. The introduction of reduced $\mathrm{Fe}$ (or $\mathrm{FeO}$ ) into the flowsheet causes some uncertainties regarding the potential to reoxidize, if necessary, $\mathrm{FeO}$ to $\mathrm{Fe}_{2} \mathrm{O}_{3}$ during the CPC processing. In the development of the IS-MIO SRAT product compositions, the assumption was made that the acid addition strategy to be used would oxidize the necessary amount of iron to meet the DWPF REDOX target. This is a critical assumption (that will need to be confirmed through experimental work) 
given that the durability model in PCCS has the potential for accounting for both $\mathrm{FeO}$ and $\mathrm{Fe}_{2} \mathrm{O}_{3}$ (if needed). In particular, the theory supporting the durability model suggests that as the $\mathrm{Fe}^{2+} / \Sigma \mathrm{Fe}$ ratio shifts from a fully oxidized state toward the upper limit of 0.33 , the durability of the glass should decrease due to the presence of FeO (Jantzen et al. (1995)). Assuming a targeted Reduction/Oxidation (REDOX) $>0$, the durability model in theory partitions the REDOX of select species (e.g., Fe) based on assigned $\Delta \mathrm{G}_{\mathrm{i}}$ values (Jantzen et al. (1995)). The $\Delta \mathrm{G}_{\mathrm{i}}$ value for $\mathrm{FeO}$ is $-21.33 \mathrm{kcal} / \mathrm{mol}$ compared to a $+14.56 \mathrm{kcal} / \mathrm{mol}$ value for $\mathrm{Fe}_{2} \mathrm{O}_{3}{ }^{5}$. Thus, there is a negative impact on the predicted durability response (via the $\Delta \mathrm{G}_{\mathrm{p}}$ model) as REDOX shifts from fully oxidized to the REDOX upper limit (for the same targeted glass composition) - the glass is predicted to become less durable. For those systems in which the upper or lower waste loading limit is defined by the $\Delta \mathrm{G}_{\mathrm{p}}$ SME acceptability criterion, as REDOX transitions from fully oxidized toward the more reduced state, the result will be to reduce the waste loading range over which acceptability would be classified. In theory, the extent or magnitude of the $\Delta \mathrm{G}_{\mathrm{P}}$ shift (and ultimately the potential impact on the projected operation window) is directly related to the total iron $(\mathrm{Fe})$ concentration and the REDOX shift.

Peeler and Edwards (2003) have recently indicated that the impact of REDOX on durability within the SB3 region (with Frit 418) can be ignored. That is, there was no significant (or practical) effect of REDOX on the measured durability response of a fully oxidized glass and its reduced compositional counterpart for the Frit 418 - SB3 glass system. With Frit 202 being a more refractory frit (less alkali), predictions of durability should not be an issue within the Frit 202-based system with MST or the alternatives being considered. With this assumption, the assessments performed in this study will be based on a fully oxidized system (e.g., the REDOX term will not be activated). It should be noted that if systems become PCT limited based on the introduction of the sorbent waste streams, then there may be a need to reassess the impact of REDOX on durability.

In the assessment of the IS-MIO sorbent case, an evaluation of the $\mathrm{Na}_{2} \mathrm{SO}_{4}$ solubility limit in glass is also necessary. The current $\mathrm{Na}_{2} \mathrm{SO}_{4}$ limit in PCCS is $0.59 \mathrm{wt} \%$ in glass (or $0.4 \mathrm{wt} \%$ expressed as $\left.\mathrm{SO}_{4}{ }^{2-}\right){ }^{6}$ Initial concerns center on the addition of excessive quantities of $\mathrm{SO}_{4}{ }^{2-}(6.6$ $\mathrm{wt} \%$ in the IS-MIO sorbent alone) that would lead to exceeding this predefined glass limit. It should be noted that $\mathrm{SO}_{4}{ }^{2-}$ was not included in the SB3 composition (see Table 3-3) since the actual level for SB3 was higher than the $\mathrm{Na}_{2} \mathrm{SO}_{4}$ limit given above. For $\mathrm{SB} 3$, glass studies were specifically performed to define the $\mathrm{SO}_{4}{ }^{2-}$ limit since it is dependent on the overall glass composition. Since the resulting sludge and SWPF compositions would be different than the existing SB3 glass composition projections, using this experimentally determined limit would not have been technically justified. Therefore, the SB3 contribution was not included and the sorbent streams were compared against each other. Excessive $\mathrm{SO}_{4}{ }^{2-}$ then only becomes a concern if the PCCS limit is exceeded or closely approaches the limit with no sludge $\mathrm{SO}_{4}{ }^{2-}$ contribution. If the IS-MIO sorbent is introduced into a flowsheet with a high $\mathrm{SO}_{4}{ }^{2-}$ content, the projected concentration of $\mathrm{SO}_{4}{ }^{2-}$ could have a significant impact to the overall flowsheet.

\footnotetext{
${ }^{5}$ More positive $\Delta \mathrm{G}_{\mathrm{i}}$ values enhance the predicted durability.

${ }^{6}$ For the Frit 418 - SB3 system, Peeler et al. (2004) established a $\mathrm{SO}_{4}$ limit in PCCS of $0.60 \mathrm{wt} \%$ in glass (or $0.88 \mathrm{wt} \%$ expressed as $\mathrm{Na}_{2} \mathrm{SO}_{4}$ ) assuming a portion of a Np-based stream from $\mathrm{H}$-Canyon would be transferred. In that study, the $\mathrm{SO}_{4}$ solubility was found to be a function of waste loading or overall glass composition and therefore the more conservative limit ( $0.4 \mathrm{wt} \%$ ) will be used in this assessment. Application of this lower limit could restrict assess to higher WLs (when appropriate this impact will be discussed). However, it should be noted that the $\mathrm{SO}_{4}$ coming from the Np-based stream is not included in the SB3 base sludge which prompted the need to increase the solubility limit. Therefore, any additional $\mathrm{SO}_{4}$ coming into this specific system could have a negative impact on the operating window.
} 
WSRC-TR-2004-00200

Revision 0

\subsection{NOMINAL STAGE ASSESSMENTS}

Table 8-1 summarizes the MAR-based Nominal Stage assessments. In addition to the MARbased projected WL interval, the property that restricts access to higher WLs is also provided in parenthesis. The primary objective is to assess the relative impact of the alternative sorbent streams to the projected operating window in relation to the Frit $202-$ SB3, baseline SWPF stream containing MST system (shaded in Table 8-1).

Table 8-1. Nominal Stage Assessment Using MAR Criteria.

\begin{tabular}{||c|c||}
\hline Option & $\begin{array}{c}\text { WL range } \\
\text { (limiting property) }\end{array}$ \\
\hline MST-Baseline & $27-43\left(\mathrm{~T}_{\mathrm{L}}\right)$ \\
\hline Optimized MST & $27-42\left(\mathrm{~T}_{\mathrm{L}}\right)$ \\
\hline Engineered MST - Case A & $27-42\left(\mathrm{~T}_{\mathrm{L}}\right)$ \\
\hline Engineered MST - Case B & None \\
\hline IS-MIO & $26-40\left(\mathrm{~T}_{\mathrm{L}}\right)$ \\
\hline
\end{tabular}

Numerous comparisons can be made with respect to these systems and their impacts to the DWPF process (based on model assessments of projected operating windows and the data presented in the appendices). In general, with the exception of the Engineered MST Case B sorbent, the projected operating windows are relatively equivalent (mid-20's for a lower WL bound ranging to lower 40's for an upper WL bound). The most striking observation from Table 8-1 is the fact that the Engineered MST Case B sorbent results in the complete elimination of the projected operating window.

In the following sections, a more detailed discussion of the projected operating windows is provided for each option. Table A.1 in Appendix A provides a summary of the MAR-based assessments for the MST-baseline as well as the other systems of interest. Table A.2 provides various predicted glass properties for these systems. The nomenclature used in Appendix A is consistent with that used by Peeler and Edwards (2002), and for a detailed discussion, the reader is referred to that report. The following assessments are performed using Frit 202 (unless otherwise specified), the current PCCS models, and associated constraints without any attempt at "optimization".

\subsection{MST-Baseline}

The projected operating window for the MST-baseline Frit 202 - SB3 system is 27 - 43\% WL. Access to lower WLs is restricted $(<27 \%)$ by predictions of high viscosity (viscosity values exceeding the upper control limit of 110 Poise without uncertainties considered). Perhaps of more interest is the upper WL (43\%) which this system can achieve based on model predictions. At $44 \%$ WL and higher, the glass system becomes $T_{L}$ limited. As expected, as the sludge WL increases in the MST-baseline option, the predicted $T_{L}$ increases until the predicted $T_{L}$ value exceeds the MAR criterion at and above WLs of 44\% (see Table A.2 in Appendix A for more details). Given the $\mathrm{T}_{\mathrm{L}}$ model is dependent upon the concentration of $\mathrm{TiO}_{2}$, one could conclude that the contribution of the MST has a significant impact on this predicted and limiting property. However, the DWPF $\mathrm{T}_{\mathrm{L}}$ predictions are also a dependent upon $\mathrm{Fe}_{2} \mathrm{O}_{3}, \mathrm{Cr}_{2} \mathrm{O}_{3}, \mathrm{NiO}, \mathrm{SiO}_{2}, \mathrm{ZrO}_{2}$, $\mathrm{Na}_{2} \mathrm{O}, \mathrm{Li}_{2} \mathrm{O}, \mathrm{MgO}, \mathrm{MnO}, \mathrm{CaO}, \mathrm{K}_{2} \mathrm{O}$, and $\mathrm{Al}_{2} \mathrm{O}_{3}$ concentrations (Brown et al. 2001) with these 
oxides having different impacts to the magnitude of the predicted value based on the associated "coefficients". That is, the relative concentration and the associated "coefficient" ultimately dictate the predicted $\mathrm{T}_{\mathrm{L}}$ value. Therefore, $\mathrm{TiO}_{2}$ may have a role in determining the $\mathrm{T}_{\mathrm{L}}$ value, but may not be the primary contributor given its concentration and "coefficient” product (see Section 8.2 for more discussion).

A primary concern with the addition of MST was the $\mathrm{TiO}_{2}$ concentration and its impact to $\mathrm{T}_{\mathrm{L}}$ or the potential to exceed the individual $\mathrm{TiO}_{2}$ solubility limit. Concern regarding the individual solubility limit was one of the drivers for the report issued by Lorier and Jantzen (2003) which raised the $\mathrm{TiO}_{2}$ solubility limit from $1 \mathrm{wt} \%$ to $2 \mathrm{wt} \%$ (in glass). With respect to the individual solubility limit, the $2 \% \mathrm{TiO}_{2}$ limit (as proposed by Lorier and Jantzen (2003)) is not exceeded until WLs of $53 \%$ or greater are reached (which can not be achieved due to predictions of $T_{L}$ ).

As mentioned in Section 7.0, the assessments are being made with the REDOX term in PCCS deactivated. However, predictions of durability are not an issue over the entire $25-60 \% \mathrm{WL}$ interval for the Frit 202 - SB3 with MST baseline system under oxidizing conditions. Given recent DWPF operations have targeted a 0.2 REDOX, the impact of the more reduced system is suggested either through a paper study or experimental assessment.

Although no formal assessment of melt rate (via experimental study) was made, literature suggests that the presence of $\mathrm{TiO}_{2}$ can have a detrimental effect on melt rate (Plodinec 1979, 1980). It should be noted that this latter statement is qualitative in nature and until quantified for the specific systems of interest should be used with caution (i.e., the option should not be withdrawn based on circumstantial evidence or the presence of relatively high $\mathrm{TiO}_{2}$ concentrations). Melt rate impacts should be assessed regardless of the sorbent material selected. $^{7}$ It is also noted that use of Frit 202 does provide a relatively large processing window but the predicted viscosities of the glasses within the $25-60 \% \mathrm{WL}$ interval could have a negative effect on melt rate relative to a lower viscosity system via the use of a specifically designed frit.

\subsection{Optimized MST}

The overall projected operating window for this system is $27-42 \%$ with predictions of $T_{L}$ still limiting access to higher WLs. As with the MST-baseline system, predictions of high viscosity restrict access to lower WLs (26\% and lower). It is interesting to note that the Optimized MST SRAT product contains significantly less $\mathrm{TiO}_{2}$ than the MST baseline flowsheet ( 0.96 versus 3.58 $\mathrm{wt} \%$, respectively). This is consistent with the $\sim 75 \%$ reduction in MST use per year. Therefore, the $\mathrm{TiO}_{2}$ concentrations in glass are lower at each WL for the Optimized MST option relative to the MST-baseline which would lead one to speculate that the $T_{L}$ predictions would be lower. However, this is not the case (see Appendix A, Table A.2 for more details). For example, the $T_{L}$ predictions at 43\% WL for the MST-baseline and Optimized MST flowsheet are $1016.93^{\circ} \mathrm{C}$ and $1027.14^{\circ} \mathrm{C}$, respectively. Given $\mathrm{TiO}_{2}$ concentrations in glass (at $43 \% \mathrm{WL}$ ) are 1.54 and 0.41 $w t \%$, respectively, this suggests that the concentrations of other components are the driver for $T_{L}$ predictions in the two systems (i.e., the coefficient for $\mathrm{TiO}_{2}$ is small within the new DWPF $\mathrm{T}_{\mathrm{L}}$ model). Regardless, the introduction of the Optimized MST sorbent results in a $1 \%$ reduction in the upper WL that can be achieved relative to the MST-baseline flowsheet.

\footnotetext{
${ }^{7}$ Experimental assessments of melt rate or waste throughput are not evaluated in this report. The reader should be aware that the melt rate program is a critical component of the integrated glass formulation strategy as it ensures that what appears attractive on paper (in terms of model-based WL ranges) does not result in a difficult feed to process. In fact, historical information indicates that the maximum waste throughput is not obtained at the maximum WL but at some lower, intermediate value within the projected operating window.
} 
With respect to the $2 \% \mathrm{TiO}_{2}$ solubility limit, the assessment indicates that this limit is not exceeded over the entire WL range from $25-60 \%$. The highest $\mathrm{TiO}_{2}$ concentration in glass is $0.58 \mathrm{wt} \%$ at $60 \% \mathrm{WL}$ - well below the current $1 \%$ limit or proposed $2 \%$ limit. In addition, predictions of durability are not an issue over the entire WL interval as would be expected for high viscosity or $\mathrm{T}_{\mathrm{L}}$ limited systems.

The 1\% decrease in WL for the optimized flowsheet (relative to the MST-baseline flowsheet) may be off-set by an assessment of melt rate or differences in the estimated process volumes of the sludge and SWPF stream which ultimately could dictate waste throughput issues. Previous testing has indicated that the maximum waste throughput is not achieved at the maximum WL obtained via model predictions but at some intermediate WL value (Smith et al. 2003, Lorier et al. 2003). Without a formal assessment of melt rate, the "breakpoint" in waste throughput can not be determined. Given the lower $\mathrm{TiO}_{2}$ levels in the Optimized MST flowsheet, there may be an advantage in melt rate given the conclusion drawn by Plodinec $(1979,1980)$ that the presence of $\mathrm{TiO}_{2}$ can have a detrimental effect on melt rate. It should be noted that this latter statement is qualitative in nature and until quantified for the specific systems of interest should be used with caution (i.e., the option should not be withdrawn based on circumstantial evidence). From a glass formulation and projected operational window perspective, there is not a significant difference between the MST and Optimized MST options. An advantage, however, may come from CPC process issues since smaller volumes of sorbent material would be processed in the CPC for the Optimized MST case.

\subsection{Engineered MST Case A}

Introduction of the Engineered MST Case A option has essentially no effect on the projected operational window relative to the MST-baseline case. More specifically, the projected operating window is $27-42 \% \mathrm{WL}$ as compared to the $27-43 \%$ window for the MST-baseline process. As with the Optimized MST case, the $1 \%$ reduction in WL could be negligible (as compared to the baseline) given similar melt rates and sludge volumes to process. At WLs less than $27 \%$, high viscosity predictions are limiting; while at WLs of $43 \%$ or greater, predictions of $\mathrm{T}_{\mathrm{L}}$ are limiting. Again, the relatively high $\mathrm{TiO}_{2}$ concentrations in the SRAT product (2.07 wt\%) do not appear to have a significant impact on the upper WL that can be achieved. The $2 \% \mathrm{TiO}_{2}$ solubility limit is not exceeded over the entire $25-60 \%$ WL interval (1.24 wt\% being the maximum amount in glass based on the $2.06 \mathrm{wt} \%$ in the SRAT at $60 \% \mathrm{WL}$ ). Predictions of durability are not an issue for this system.

\subsection{Engineered MST Case B}

Introduction of the Engineered MST Case B option has an extremely negative impact on the projected operating window (relative to the MST-baseline case). More specifically, an operating window is non-existent for this case. Predictions of high viscosity restrict processing from $25-$ $37 \%$ WL; while predictions of $\mathrm{T}_{\mathrm{L}}$ limit access to WLs of 38\% or higher. The primary reason for the non-existent window is the fact that the Engineered MST Case B SRAT product is extremely high in $\mathrm{Al}_{2} \mathrm{O}_{3}$ (25.2 wt\%) and low in $\mathrm{Na}_{2} \mathrm{O}(19.88 \mathrm{wt} \%)$ as compared to the MST-baseline (as well as other alternative sorbent) SRAT products. The high $\mathrm{Al}_{2} \mathrm{O}_{3}$ content and low $\mathrm{Na}_{2} \mathrm{O}$ content of the Frit 202 - SB3 system result in increased predicted values for viscosity and $\mathrm{T}_{\mathrm{L}}$. Thus, the Engineered MST Case B sorbent could not be processed with Frit 202 and SB3. However, this option should not be ruled out from further consideration (from a glass formulation perspective) 
given the possible use of an alternative frit to restore the projected operating window (see Section 8.6).

\subsection{IS-MIO}

The overall projected operating window with the addition of the IS-MIO option is $26-40 \%$ WL. As with all systems, access to lower WLs is restricted by the predictions of high viscosity. At $41 \%$ WL, the IS-MIO-based flowsheet becomes $\mathrm{T}_{\mathrm{L}}$ limited - again, similar to the other flowsheets. The $2 \%$ reduction in the maximum WL attainable relative to the MST-baseline flowsheet may be significant if melt rates are assumed to be equivalent at each WL and the maximum waste throughput is achieved at 41 or $42 \% \mathrm{WL}$.

A primary concern with the addition of IS-MIO process was the introduction of $\mathrm{SO}_{4}{ }^{2-}$ to the overall flowsheet. Based on the assessments, the $\mathrm{SO}_{4}{ }^{2-}$ concentrations in glass do not exceed the $0.4 \mathrm{wt} \%$ constraint in PCCS over the entire WL interval of $25-60 \%$. The maximum amount of $\mathrm{SO}_{4}{ }^{2-}$ in glass is $0.13 \mathrm{wt} \%$ which occurs at $60 \% \mathrm{WL}$ with $0.222 \mathrm{wt} \% \mathrm{SO}_{4}{ }^{2-}$ in the IS-MIO SRAT product. ${ }^{8}$ Although the $\mathrm{SO}_{4}{ }^{2-}$ solubility limit was not exceeded with the introduction of the ISMIO process (i.e., did not limit the projected operating window), its introduction into a sludge batch with (or accounting for) $\mathrm{SO}_{4}{ }^{2-}$ could make this single point solubility limit a constraining parameter.

\subsection{Impact of Frit Composition Changes}

In this section, Frit 433 (a less refractory (more alkali) containing frit as compared to Frit 202) is applied to each option to demonstrate the impact of frit composition on the projected operating windows. The primary interest is focused on the Engineered MST Case B flowsheet and the fact that Frit 202 was consistently used to assess each option without consideration of alternative frits to compensate for the compositional differences for the incoming SRAT products. Application of Frit 202 with the Engineered MST Case B sorbent resulted in the complete elimination of the projected operating window.

Frit 433 should not be considered an "optimized” frit for the Engineered MST Case B option. As with Frit 202, it is being used out of convenience, and based on previous glass formulation experience its composition should have a positive impact for the introduction of the Engineered MST Case B option into the DWPF process. In fact, its use may have negative impacts on the MST baseline and other alternative sorbents being considered relative to Frit 202.

Table 8-2 summarizes the projected operational windows for the MST-baseline and other alternative sorbents with the use of Frit 433. In this assessment, the same SRAT compositions (shown in Table 3-3) are used, with the difference being that the sludges are now coupled with Frit 433 instead of Frit 202.

The most striking feature about Table 8-2 is the fact that the only system that has an operating window is the Engineered MST Case B option. All other flowsheets (including the MST baseline) have no operational window - each being limited by predictions of durability over the entire $25-60 \% \mathrm{WL}$ range. The application of Frit 433 converts the once $T_{L}$ limited systems to durability limited systems resulting in complete closure of the projected operating windows. This

\footnotetext{
${ }^{8}$ The SB3 sludge used in this assessment did not account for any $\mathrm{SO}_{4}$ concentration associated with SB3 (see Table 33).
} 
implies that a frit lying between Frit 202 and Frit 433 (in terms of composition) may be "optimal” with respect to the model-based projected operating windows.

For the Engineered MST Case B option and Frit 433, the projected operating window is $25-49 \%$ WL with the system being $T_{\mathrm{L}}$ limited at WLs of $50 \%$ or greater. This projected operating window shows a significant advantage over the MST-baseline and other alternative sorbents with the use of Frit 202 (where the highest WL attainable was 43\% for the MST-baseline process). This demonstrates the ability of frit development efforts to compositionally compensate for the incoming sludge to develop larger operating windows.

Although a significant advantage in terms of the projected WL is shown for the Engineered MST Case B option with Frit 433 relative to the Frit 202 based systems, caution should be used to make the conclusion that the projected operating windows could not be altered through the use of strategic frit development approaches. In fact, a high probability exists that the "WL gap" between the different systems could be minimized by strategic frit development efforts.

Table 8-2. Comparison of Frit 202 and Frit 433.

\begin{tabular}{||c|c|c||}
\hline Option & Frit 202 & Frit 433 \\
\hline MST-Baseline & $27-43\left(\mathrm{~T}_{\mathrm{L}}\right)$ & None \\
\hline Optimized MST & $27-42\left(\mathrm{~T}_{\mathrm{L}}\right)$ & None \\
\hline Engineered MST - Case A & $27-42\left(\mathrm{~T}_{\mathrm{L}}\right)$ & None \\
\hline Engineered MST - Case B & None & $25-49\left(\mathrm{~T}_{\mathrm{L}}\right)$ \\
\hline IS-MIO & $26-40\left(\mathrm{~T}_{\mathrm{L}}\right)$ & None \\
\hline
\end{tabular}

The bottom line is that introduction of the SWPF waste stream should not be made in a vacuum ignoring the potential impacts to the overall process. In fact, if these streams are well characterized and blending strategies are known in advance, frit development efforts can account or compositionally compensate for these streams resulting in projected operating windows of relatively large size covering a WL range of interest to DWPF. The unknown factor is the assessment of melt rate which lowers the probability that what appears attractive on paper (based on model predictions only) does not result in a difficult feed to process.

\subsection{Impact to Canister Production Total}

In this section, the impact of the alternative sorbents on the projected DWPF canister count (i.e., the number of canisters resulting from the introduction of the sorbent) is made. This approach is independent of a canister production rate approach (i.e., no melter throughput considerations) which would require an assessment of melt rate for each system to determine the WL at which maximum waste throughput occurs.

The approach makes the assumptions that melt rates are constant among the various options at each WL and that melt rate increases with increased WL (a trend that has not been observed in previous tests but one that would drive DWPF to target the maximum WL achievable). Therefore, the system demonstrating access to higher WLs could have an advantage in terms of minimizing the number of canisters assuming sludge and SWPF volumes are comparable. This approach basically uses the maximum WLs shown in this report (with either Frit 202 or Frit 433) and draws general conclusions regarding the number of canisters that each system would produce (per year). Obviously, the fact that maximum WLs were not "optimized” for each system 
provides a measure of uncertainty and potential bias in the projected number of canisters. The primary drivers for this assessment are the upper WL that can be achieved and the volume of sludge to be processed.

The total number of canisters that would be produced (per year) was calculated as follows:

$$
\frac{\text { Total canisters }}{\text { year }}=\left(\frac{k g s \text { sludge }}{\text { year }}\right)\left(\frac{\text { lbs sludge }}{k g \text { sludge }}\right)\left(\frac{\text { lbs glass }}{\text { lbs sludge }}\right)\left(\frac{\text { canister }}{\text { lb glass }}\right)
$$

The total mass (kgs) of sludge per year was obtained based on the mass of sludge per SRAT batch and assuming 45 SRAT batches were processed in a year (see discussion in Section 5.0 for more detail). The total mass (in kgs) was then converted to pounds of sludge (multiply by 2.2). To determine the amount of glass produced for each sorbent option, the total mass of sludge was divided by the maximum attainable WL based on model predictions. Assuming $4000 \mathrm{lbs}$ of glass per DWPF canister, the total number of canisters produced per year was computed for each option.

Table 8-3 summarizes the total sludge mass per year, maximum achievable WL (per the modelbased predictions), the kgs of glass produced per year, and the estimated total number of canisters for each option. The minimum number of canisters produced (299) within a year is based on the Engineered MST - Case B option. The maximum number of canisters produced (325) results from the IS-MIO process. The difference (26 canisters) is not viewed as significant given the assumptions made. 
Table 8-3. Maximum WL, Sludge Volume, and Estimated \# of Canisters for Each Option.

\begin{tabular}{|c|c|c|c|c|c|}
\hline Option & $\begin{array}{l}\text { Total Mass / } \\
\text { Batch (kgs) }\end{array}$ & $\begin{array}{c}\text { Total Mass / } \\
\text { year }^{9} \text { (kgs) }\end{array}$ & $\begin{array}{l}\text { Maximum WL } \\
\text { (\%, oxide basis) }\end{array}$ & $\begin{array}{c}\text { kgs of glass } \\
\text { produced / year }{ }^{10}\end{array}$ & $\begin{array}{c}\text { \# of Canisters / } \\
\text { year }\end{array}$ \\
\hline MST-Baseline & 5353.9 & 240,926 & 43 & 560,293 & 308 \\
\hline Optimized MST & 5184.7 & 233,311 & 42 & 555,502 & 306 \\
\hline Engineered MST - Case A & 5235.1 & 235,581 & 42 & 560,908 & 309 \\
\hline Engineered MST - Case $\mathrm{B}^{12}$ & 5911.0 & 265,997 & 49 & 542,851 & 299 \\
\hline IS-MIO & 5250.1 & 236,253 & 40 & 590,633 & 325 \\
\hline
\end{tabular}

\footnotetext{
${ }^{9}$ Total mass per year assumes 45 SRAT batches are processed.

${ }^{10} \mathrm{Kg}$ of glass produced per year is the mass of SRAT product (sludge and sorbent) divided by the maximum WL.

${ }^{11}$ \# of canisters is calculated by converting the kgs of glass produced per year to lbs of glass produced per year (multiply by 2.2) then dividing by 4000 lbs (estimated amount of glass in a DWPF canister).

12 \# of canisters for the Engineered MST - Case B option is based on the use of Frit 433; whereas all other options are based on the use of Frit 202.
} 
WSRC-TR-2004-00200

Revision 0

\subsection{SUMMARY}

The objective of this report was to evaluate the relative impacts of alternative Sr/actinide removal process sorbents on the Defense Waste Processing Facility (DWPF). The specific processes evaluated included: (1) optimized MST, (2) Engineered MST Case A, (3) Engineered MST Case B, and (4) IS-MIO. The impacts were assessed relative to the Frit 202 - SB3 and SWPF stream containing MST flowsheet (the current baseline technology) and included processing issues associated primarily with the Chemical Processing Cell (CPC) and projected operating windows (which were based on model predictions and were represented in terms of a waste loading interval). In addition, the total number of canisters (per year) produced for each option was assessed.

Based on the limited assessments, all of the options being considered are still plausible from a DWPF CPC and glass formulation perspective. Compared to the baseline MST sorbent and process, no increase in acid demand would be expected for the alternative sorbents and no significant processing differences have been identified with any option based on the paper assessment. With respect to projected operating windows, the Optimized MST, Engineered MST Case A, and IS-MIO options resulted in upper WLs of 42, 42, and 40\%, respectively, as compared to the MST baseline of 43\% WL. The use of Frit 202 with the Engineered MST Case B sorbent resulted complete elimination of the operating window. However, use of Frit 433 with the Engineered MST Case B sorbent result in a higher projected upper WL of $49 \%$ as compared to the MST baseline. Although a potentially significant advantage in terms of the projected WL is shown for the Engineered MST Case B option with Frit 433 relative to the Frit 202-based systems, caution should be used in making the conclusion that the projected operating windows could not be altered through the use of strategic frit development approaches. In fact, a high probability exists that the "WL gap" among the different systems could be minimized by strategic frit development efforts.

Projections regarding the total number of cans produced annually suggested very little differences among the various options. The difference among the options in terms of canister count was approximately 26 per year, which is not viewed as significant given the assumptions made. 


\subsection{FUTURE WORK}

Based on the limited assessments performed in this study, all of the sorbent options being considered are plausible from a DWPF CPC and glass formulation perspective. However, various issues regarding the processability of the feed through the CPC and melter have not been assessed. These open issues are outlined below and there is a need to:

(1) Demonstrate processability of the sorbent streams with stimulant studies

- $\quad$ with respect to the CPC, issues associated with rheology, particle size, anti-foam additions, $\mathrm{H}_{2}$ generation, and SRAT processing time are of interest

a. the Engineered MST Case B appears to present the largest challenge with respect to rheology since it contains the highest total and insoluble solids content

- $\quad$ with respect to the melter, issues associated with melt rate and cold cap behavior are of interest to reduce the risk that what appears attractive on paper (based on model-based predictions) does not result in a difficult feed to process

a. other potential processing issues associated with carry-over organics should be evaluated with respect to melter flammability concerns

(2) Address potential analytical "needs" associated with the sorbent materials

(3) Perform frit development activities to "optimize" the flowsheet with respect to projected operating windows and melt rate

(4) Address potential REDOX issues associated with CPC processing and product performance (durability)

(5) Assess $\mathrm{SO}_{4}{ }^{2-}$ solubility limits with the IS-MIO process if it is being considered for implementation with a high $\mathrm{SO}_{4}^{2-}$-based sludge

(6) Assess the potential for the projected operating window to be limited by canister dose rates instead of model predictions (especially at high WLs) 
WSRC-TR-2004-00200

Revision 0

\subsection{REFERENCES}

ASTM 2002. Standard Test Methods for Determining Chemical Durability of Nuclear Waste Glasses: The Product Consistency Test (PCT), ASTM C-1285-2002.

Arafat, HA, AV Gelis, and GF Vandegrift. 2002. Operational Envelope for Studies Using Magnetite to Remove Strontium and Actinides from SRS Tank Waste, ANL/CMT/MAGNETITE2002/01-Rev. 1, Argonne National Laboratory, Argonne, Illinois.

Baich, MA, CC Herman, DC Koopman, DR Best, TK Snyder, and MF Williams. 2003. Processing Options and Impact of Incorporation of ARP in the DWPF Process Flow Sheet, WSRC-TR-2003-00326, Revision 0, Westinghouse Savannah River Company, Aiken, South Carolina.

Bray, L and F Hara. 1991. Use of Titanium-Treated Zeolite for Plutonium, Strontium, and Cesium Removal from West Valley Alkaline Wastes and Sludge Wash Waters, PNL-SA-19697, Pacific Northwest Laboratory, Richland, Washington.

Brown KG, CM Jantzen, and G Ritzhaupt. 2001. Relating Liquidus Temperature to Composition for Defense Waste Processing Facility (DWPF) Process Control, WSRC-TR-2001-00520, Revision 0, Westinghouse Savannah River Company, Aiken, South Carolina.

Brown, KG, RL Postles, and TB Edwards, 2002. SME Acceptability Determination for DWPF Process Control, WSRC-TR-95-0364, Revision 4, Westinghouse Savannah River Company, Aiken, South Carolina.

Caldwell, TB, DP Chew, HH Elder, MJ Mahoney, and FE Wise. 2002. PMP Supplement to the HLW System Plan, Rev. 13, HLW-2002-00161, Westinghouse Savannah River Company, Aiken, South Carolina.

Cathey, SS. 2003. Execution Plan Summary, WSRC-RP-2003-01935, Westinghouse Savannah River Company, Aiken, South Carolina.

Click, DR and JM Pareizs. 2003. Composition of SRAT Feed for the Sludge Batch 3 Acceptance Evaluation in the SRTC Shielded Cells, WSRC-RP-2003-01003, Revision 0, Westinghouse Savannah River Company, Aiken, South Carolina.

Collins, JL. 1998. U.S. Patent No. 5,821,186, Method of Preparing Hydrous Titanium Oxide Gels and Spherules, issued 10/13/1998.

Edwards, RE. 2003. Suggested Design Basis for SWPF Feed - Conceptual Design Phase, Internal WSRC Memorandum, Westinghouse Savannah River Company, Aiken, South Carolina.

Hobbs, DT. 2002. Uranium Loading onto MST, SRT-LWP-2002-0105, Westinghouse Savannah River Company, Aiken, South Carolina.

Jantzen, CM. 1988. Glass Composition and Frit Formulation Developed for DWPF, DPST-88952, E.I. du Pont de Nemours and Company, Savannah River Laboratory, Aiken, South Carolina. 
Jantzen, CM, JB Pickett, KG Brown, TB Edwards, and DC Beam. 1995. Process/Product Models for the Defense Waste Processing Facility (DWPF): Part I. Predicting Glass Durability from Composition Using a Thermodynamic Hydration Energy Reaction Model (THERMO) (U), WSRC-TR-93-672, Revision 1, Volume 1, Westinghouse Savannah River Company, Aiken, South Carolina.

Lambert, DP, TH Lorier, DK Peeler, and ME Stone. 2001. Melt Rate Improvement for DWPF MB3: Summary and Recommendations, WSRC-TR-2001-00148, Westinghouse Savannah River Company, Aiken, South Carolina.

Lorier TH, DK Peeler, and DC Koopman. 2003. Sludge Batch 3 Melt Rate Assessment, WSRCTR-2003-00027, Revision 0, Westinghouse Savannah River Company, Aiken, South Carolina.

Lorier, TH and CM Jantzen. 2003. Evaluation of the $\mathrm{TiO}_{2}$ Limit for DWPF Glass, WSRC-TR2003-00396, Revision 0, Westinghouse Savannah River Company, Aiken, South Carolina.

Painter, GW. 2003. Monosodium Titatante (MST) Performance in Removing Actinides/Strontium from Feed at the Salt Waste Processing Facility (SWPF), PE-03-166, Westinghouse Savannah River Company, Aiken, South Carolina.

Peeler, DK and TB Edwards. 2002. Frit Development for Sludge Batch 3, WSRC-TR-200200491, Revision 0, Westinghouse Savannah River Company, Aiken, South Carolina.

Peeler, DK and TB Edwards. 2003. Projected Operational Windows for Various Sludge Batch 2/3 Blends: A Progression from a PAR to a MAR Assessment, WSRC-TR-2003-00509, Revision 0, Westinghouse Savannah River Company, Aiken, South Carolina.

Pereira, C, SB Aase, AV Gellis, MC Regalbuto, GF Vandegrift, K Martin, S Serkiz, SG Subosits, and SD Fink. 2004. Preliminary Flowsheet for the IS-MIO Process for Sr and Actinides Removal from SRS Salt Waste, ANL/CMT/IS-MIO-2004/01, Argonne National Laboratory, Chicago, Illinois.

Plodinec, MJ. 1979. Development of Glass Compositions for Immobilization of SRP Waste, USDOE Report DP-1517.

Plodinec, MJ. 1980. “Improved Glass Compositions for Immobilization of SRP Waste”, Scientific Basis for Nuclear Waste Management (Vol. 2), Editor - Clyde J. M. Northrup, Jr., Plenum Press, New York.

Schulz, W. 1980. “Removal of Radionuclides from Hanford Defense Waste Solutions”, RHOSA-51.

Smith, ME, TH Lorier, and TM Jones. 2003. SMRF and MRF Melt Rate Testing for SB2/3 (Case $6 b-250$ Canisters), WSRC-TR-2003-00466, Revision 0, Westinghouse Savannah River Company, Aiken, South Carolina. 
WSRC-TR-2004-00200

Revision 0

\section{APPENDIX A}

MAR Results for Nominal Stage Assessments 
WSRC-TR-2004-00200

Revision 0

Table A.2. Various Property Predictions for the Frit 418 - SB2/3 System (Baseline and Secondary Streams)

\begin{tabular}{|c|c|c|}
\hline Glass System & WL (\%) & MAR Status \\
\hline MST Baseline Frit 202 & 25 & hvisc \\
\hline MST Baseline Frit 202 & 26 & hvisc \\
\hline MST Baseline Frit 202 & 27 & - \\
\hline MST Baseline Frit 202 & 28 & - \\
\hline MST Baseline Frit 202 & 29 & - \\
\hline MST Baseline Frit 202 & 30 & - \\
\hline MST Baseline Frit 202 & 31 & - \\
\hline MST Baseline Frit 202 & 32 & - \\
\hline MST Baseline Frit 202 & 33 & - \\
\hline MST Baseline Frit 202 & 34 & - \\
\hline MST Baseline Frit 202 & 35 & - \\
\hline MST Baseline Frit 202 & 36 & - \\
\hline MST Baseline Frit 202 & 37 & - \\
\hline MST Baseline Frit 202 & 38 & - \\
\hline MST Baseline Frit 202 & 39 & - \\
\hline MST Baseline Frit 202 & 40 & - \\
\hline MST Baseline Frit 202 & 41 & - \\
\hline MST Baseline Frit 202 & 42 & - \\
\hline MST Baseline Frit 202 & 43 & - \\
\hline MST Baseline Frit 202 & 44 & $\mathrm{~T}_{\mathrm{L}}$ \\
\hline MST Baseline Frit 202 & 45 & $\mathrm{~T}_{\mathrm{L}}$ \\
\hline MST Baseline Frit 202 & 46 & $\mathrm{~T}_{\mathrm{L}}$ \\
\hline MST Baseline Frit 202 & 47 & $\mathrm{~T}_{\mathrm{L}}$ \\
\hline MST Baseline Frit 202 & 48 & $\mathrm{~T}_{\mathrm{L}}$ \\
\hline MST Baseline Frit 202 & 49 & $\mathrm{~T}_{\mathrm{L}}$ \\
\hline MST Baseline Frit 202 & 50 & $\mathrm{~T}_{\mathrm{L}}$ \\
\hline MST Baseline Frit 202 & 51 & $\mathrm{~T}_{\mathrm{L}}$, lvisc \\
\hline MST Baseline Frit 202 & 52 & $\mathrm{~T}_{\mathrm{L}}$, lvisc \\
\hline MST Baseline Frit 202 & 53 & $\mathrm{~T}_{\mathrm{L}}$, lvisc \\
\hline MST Baseline Frit 202 & 54 & $\mathrm{~T}_{\mathrm{L}}$, lvisc, $\mathrm{TiO}_{2}$ \\
\hline MST Baseline Frit 202 & 55 & $\mathrm{~T}_{\mathrm{L}}$, lvisc, $\mathrm{TiO}_{2}$ \\
\hline MST Baseline Frit 202 & 56 & $\mathrm{~T}_{\mathrm{L}}$, lvisc, $\mathrm{TiO}_{2}$ \\
\hline MST Baseline Frit 202 & 57 & $\mathrm{~T}_{\mathrm{L}}$, lvisc, $\mathrm{TiO}_{2}$ \\
\hline MST Baseline Frit 202 & 58 & $\mathrm{~T}_{\mathrm{L}}$, lvisc, $\mathrm{TiO}_{2}$ \\
\hline MST Baseline Frit 202 & 59 & $\mathrm{~T}_{\mathrm{L}}$, lvisc, $\mathrm{TiO}_{2}$ \\
\hline MST Baseline Frit 202 & 60 & $\mathrm{~T}_{\mathrm{L}}$, lvisc, $\mathrm{TiO}_{2}$ \\
\hline
\end{tabular}


Table A.2. Various Property Predictions for the Frit 418 - SB2/3 System (Baseline and Secondary Streams)

\begin{tabular}{|c|c|c|}
\hline Glass System & WL (\%) & MAR Status \\
\hline MST Optimized Frit 202 & 25 & hvisc \\
\hline MST Optimized Frit 202 & 26 & hvisc \\
\hline MST Optimized Frit 202 & 27 & - \\
\hline MST Optimized Frit 202 & 28 & - \\
\hline MST Optimized Frit 202 & 29 & - \\
\hline MST Optimized Frit 202 & 30 & - \\
\hline MST Optimized Frit 202 & 31 & - \\
\hline MST Optimized Frit 202 & 32 & - \\
\hline MST Optimized Frit 202 & 33 & - \\
\hline MST Optimized Frit 202 & 34 & - \\
\hline MST Optimized Frit 202 & 35 & - \\
\hline MST Optimized Frit 202 & 36 & - \\
\hline MST Optimized Frit 202 & 37 & - \\
\hline MST Optimized Frit 202 & 38 & - \\
\hline MST Optimized Frit 202 & 39 & - \\
\hline MST Optimized Frit 202 & 40 & - \\
\hline MST Optimized Frit 202 & 41 & - \\
\hline MST Optimized Frit 202 & 42 & - \\
\hline MST Optimized Frit 202 & 43 & $\mathrm{~T}_{\mathrm{L}}$ \\
\hline MST Optimized Frit 202 & 44 & $\mathrm{~T}_{\mathrm{L}}$ \\
\hline MST Optimized Frit 202 & 45 & $\mathrm{~T}_{\mathrm{L}}$ \\
\hline MST Optimized Frit 202 & 46 & $\mathrm{~T}_{\mathrm{L}}$ \\
\hline MST Optimized Frit 202 & 47 & $\mathrm{~T}_{\mathrm{L}}$ \\
\hline MST Optimized Frit 202 & 48 & $\mathrm{~T}_{\mathrm{L}}$ \\
\hline MST Optimized Frit 202 & 49 & $\mathrm{~T}_{\mathrm{L}}$ \\
\hline MST Optimized Frit 202 & 50 & $\mathrm{~T}_{\mathrm{L}}$ \\
\hline MST Optimized Frit 202 & 51 & $\mathrm{~T}_{\mathrm{L}}$, lvisc \\
\hline MST Optimized Frit 202 & 52 & $\mathrm{~T}_{\mathrm{L}}$, lvisc \\
\hline MST Optimized Frit 202 & 53 & $\mathrm{~T}_{\mathrm{L}}$, lvisc \\
\hline MST Optimized Frit 202 & 54 & $\mathrm{~T}_{\mathrm{L}}$, lvisc \\
\hline MST Optimized Frit 202 & 55 & $\mathrm{~T}_{\mathrm{L}}$, lvisc \\
\hline MST Optimized Frit 202 & 56 & $\mathrm{~T}_{\mathrm{L}}$, lvisc \\
\hline MST Optimized Frit 202 & 57 & $\mathrm{~T}_{\mathrm{L}}$, lvisc \\
\hline MST Optimized Frit 202 & 58 & $\mathrm{~T}_{\mathrm{L}}$, lvisc \\
\hline MST Optimized Frit 202 & 59 & $\mathrm{~T}_{\mathrm{L}}$, lvisc \\
\hline MST Optimized Frit 202 & 60 & $\mathrm{~T}_{\mathrm{L}}$, lvisc \\
\hline Engr MST Case A Frit 202 & 25 & hvisc \\
\hline
\end{tabular}


Table A.2. Various Property Predictions for the Frit 418 - SB2/3 System (Baseline and Secondary Streams)

\begin{tabular}{|c|c|c|}
\hline Glass System & WL (\%) & MAR Status \\
\hline Engr MST Case A Frit 202 & 26 & hvisc \\
\hline Engr MST Case A Frit 202 & 27 & - \\
\hline Engr MST Case A Frit 202 & 28 & - \\
\hline Engr MST Case A Frit 202 & 29 & - \\
\hline Engr MST Case A Frit 202 & 30 & - \\
\hline Engr MST Case A Frit 202 & 31 & - \\
\hline Engr MST Case A Frit 202 & 32 & - \\
\hline Engr MST Case A Frit 202 & 33 & -- \\
\hline Engr MST Case A Frit 202 & 34 & - \\
\hline Engr MST Case A Frit 202 & 35 & - \\
\hline Engr MST Case A Frit 202 & 36 & - \\
\hline Engr MST Case A Frit 202 & 37 & - \\
\hline Engr MST Case A Frit 202 & 38 & - \\
\hline Engr MST Case A Frit 202 & 39 & - \\
\hline Engr MST Case A Frit 202 & 40 & - \\
\hline Engr MST Case A Frit 202 & 41 & - \\
\hline Engr MST Case A Frit 202 & 42 & - \\
\hline Engr MST Case A Frit 202 & 43 & $\mathrm{~T}_{\mathrm{L}}$ \\
\hline Engr MST Case A Frit 202 & 44 & $\mathrm{~T}_{\mathrm{L}}$ \\
\hline Engr MST Case A Frit 202 & 45 & $\mathrm{~T}_{\mathrm{L}}$ \\
\hline Engr MST Case A Frit 202 & 46 & $\mathrm{~T}_{\mathrm{L}}$ \\
\hline Engr MST Case A Frit 202 & 47 & $\mathrm{~T}_{\mathrm{L}}$ \\
\hline Engr MST Case A Frit 202 & 48 & $\mathrm{~T}_{\mathrm{L}}$ \\
\hline Engr MST Case A Frit 202 & 49 & $\mathrm{~T}_{\mathrm{L}}$ \\
\hline Engr MST Case A Frit 202 & 50 & $\mathrm{~T}_{\mathrm{L}}$ \\
\hline Engr MST Case A Frit 202 & 51 & $\mathrm{~T}_{\mathrm{L}}$, lvisc \\
\hline Engr MST Case A Frit 202 & 52 & $\mathrm{~T}_{\mathrm{L}}$, lvisc \\
\hline Engr MST Case A Frit 202 & 53 & $\mathrm{~T}_{\mathrm{L}}$, lvisc \\
\hline Engr MST Case A Frit 202 & 54 & $\mathrm{~T}_{\mathrm{L}}$, lvisc \\
\hline Engr MST Case A Frit 202 & 55 & $\mathrm{~T}_{\mathrm{L}}$, lvisc \\
\hline Engr MST Case A Frit 202 & 56 & $\mathrm{~T}_{\mathrm{L}}$, lvisc \\
\hline Engr MST Case A Frit 202 & 57 & $\mathrm{~T}_{\mathrm{L}}$, lvisc \\
\hline Engr MST Case A Frit 202 & 58 & $\mathrm{~T}_{\mathrm{L}}$, lvisc \\
\hline Engr MST Case A Frit 202 & 59 & $\mathrm{~T}_{\mathrm{L}}$, lvisc \\
\hline Engr MST Case A Frit 202 & 60 & $\mathrm{~T}_{\mathrm{L}}$, lvisc \\
\hline Engr MST Case B Frit 202 & 25 & hvisc \\
\hline Engr MST Case B Frit 202 & 26 & hvisc \\
\hline
\end{tabular}


Table A.2. Various Property Predictions for the Frit 418 - SB2/3 System (Baseline and Secondary Streams)

\begin{tabular}{|c|c|c|}
\hline Glass System & WL (\%) & MAR Status \\
\hline Engr MST Case B Frit 202 & 27 & hvisc \\
\hline Engr MST Case B Frit 202 & 28 & hvisc \\
\hline Engr MST Case B Frit 202 & 29 & hvisc \\
\hline Engr MST Case B Frit 202 & 30 & hvisc \\
\hline Engr MST Case B Frit 202 & 31 & hvisc \\
\hline Engr MST Case B Frit 202 & 32 & hvisc \\
\hline Engr MST Case B Frit 202 & 33 & hvisc \\
\hline Engr MST Case B Frit 202 & 34 & hvisc \\
\hline Engr MST Case B Frit 202 & 35 & hvisc \\
\hline Engr MST Case B Frit 202 & 36 & hvisc \\
\hline Engr MST Case B Frit 202 & 37 & hvisc \\
\hline Engr MST Case B Frit 202 & 38 & $\mathrm{~T}_{\mathrm{L}}$ \\
\hline Engr MST Case B Frit 202 & 39 & $\mathrm{~T}_{\mathrm{L}}$ \\
\hline Engr MST Case B Frit 202 & 40 & $\mathrm{~T}_{\mathrm{L}}$ \\
\hline Engr MST Case B Frit 202 & 41 & $\mathrm{~T}_{\mathrm{L}}$ \\
\hline Engr MST Case B Frit 202 & 42 & $\mathrm{~T}_{\mathrm{L}}$ \\
\hline Engr MST Case B Frit 202 & 43 & $\mathrm{~T}_{\mathrm{L}}$ \\
\hline Engr MST Case B Frit 202 & 44 & $\mathrm{~T}_{\mathrm{L}}$ \\
\hline Engr MST Case B Frit 202 & 45 & $\mathrm{~T}_{\mathrm{L}}$ \\
\hline Engr MST Case B Frit 202 & 46 & $\mathrm{~T}_{\mathrm{L}}$ \\
\hline Engr MST Case B Frit 202 & 47 & $\mathrm{~T}_{\mathrm{L}}$ \\
\hline Engr MST Case B Frit 202 & 48 & $\mathrm{~T}_{\mathrm{L}}$ \\
\hline Engr MST Case B Frit 202 & 49 & $\mathrm{~T}_{\mathrm{L}}$ \\
\hline Engr MST Case B Frit 202 & 50 & $\mathrm{~T}_{\mathrm{L}}$ \\
\hline Engr MST Case B Frit 202 & 51 & $\mathrm{~T}_{\mathrm{L}}$ \\
\hline Engr MST Case B Frit 202 & 52 & $\mathrm{~T}_{\mathrm{L}}$ \\
\hline Engr MST Case B Frit 202 & 53 & $\mathrm{~T}_{\mathrm{L}}$ \\
\hline Engr MST Case B Frit 202 & 54 & $\mathrm{~T}_{\mathrm{L}}$ \\
\hline Engr MST Case B Frit 202 & 55 & $\mathrm{~T}_{\mathrm{L}}$ \\
\hline Engr MST Case B Frit 202 & 56 & $\mathrm{~T}_{\mathrm{L}}$ \\
\hline Engr MST Case B Frit 202 & 57 & $\mathrm{~T}_{\mathrm{L}}$ \\
\hline Engr MST Case B Frit 202 & 58 & $\mathrm{~T}_{\mathrm{L}}$ \\
\hline Engr MST Case B Frit 202 & 59 & $\mathrm{~T}_{\mathrm{L}}$ \\
\hline Engr MST Case B Frit 202 & 60 & $\mathrm{~T}_{\mathrm{L}}$ \\
\hline ISMIO Frit 202 & 25 & hvisc \\
\hline ISMIO Frit 202 & 26 & - \\
\hline ISMIO Frit 202 & 27 & - \\
\hline
\end{tabular}


Table A.2. Various Property Predictions for the Frit 418 - SB2/3 System (Baseline and Secondary Streams)

\begin{tabular}{|c|c|c|}
\hline Glass System & WL (\%) & MAR Status \\
\hline ISMIO Frit 202 & 28 & - \\
\hline ISMIO Frit 202 & 29 & - \\
\hline ISMIO Frit 202 & 30 & - \\
\hline ISMIO Frit 202 & 31 & - \\
\hline ISMIO Frit 202 & 32 & - \\
\hline ISMIO Frit 202 & 33 & - \\
\hline ISMIO Frit 202 & 34 & - \\
\hline ISMIO Frit 202 & 35 & - \\
\hline ISMIO Frit 202 & 36 & - \\
\hline ISMIO Frit 202 & 37 & - \\
\hline ISMIO Frit 202 & 38 & - \\
\hline ISMIO Frit 202 & 39 & - \\
\hline ISMIO Frit 202 & 40 & - \\
\hline ISMIO Frit 202 & 41 & $\mathrm{~T}_{\mathrm{L}}$ \\
\hline ISMIO Frit 202 & 42 & $\mathrm{~T}_{\mathrm{L}}$ \\
\hline ISMIO Frit 202 & 43 & $\mathrm{~T}_{\mathrm{L}}$ \\
\hline ISMIO Frit 202 & 44 & $\mathrm{~T}_{\mathrm{L}}$ \\
\hline ISMIO Frit 202 & 45 & $\mathrm{~T}_{\mathrm{L}}$ \\
\hline ISMIO Frit 202 & 46 & $\mathrm{~T}_{\mathrm{L}}$ \\
\hline ISMIO Frit 202 & 47 & $\mathrm{~T}_{\mathrm{L}}$ \\
\hline ISMIO Frit 202 & 48 & $\mathrm{~T}_{\mathrm{L}}$ \\
\hline ISMIO Frit 202 & 49 & $\mathrm{~T}_{\mathrm{L}}$ \\
\hline ISMIO Frit 202 & 50 & $\mathrm{~T}_{\mathrm{L}}$, lvisc \\
\hline ISMIO Frit 202 & 51 & $\mathrm{~T}_{\mathrm{L}}$, lvisc \\
\hline ISMIO Frit 202 & 52 & $\mathrm{~T}_{\mathrm{L}}$, lvisc \\
\hline ISMIO Frit 202 & 53 & $\mathrm{~T}_{\mathrm{L}}$, lvisc \\
\hline ISMIO Frit 202 & 54 & $\mathrm{~T}_{\mathrm{L}}$, lvisc \\
\hline ISMIO Frit 202 & 55 & $\mathrm{~T}_{\mathrm{L}}$, lvisc \\
\hline ISMIO Frit 202 & 56 & $\mathrm{~T}_{\mathrm{L}}$, lvisc \\
\hline ISMIO Frit 202 & 57 & $\mathrm{~T}_{\mathrm{L}}$, lvisc \\
\hline ISMIO Frit 202 & 58 & $\mathrm{~T}_{\mathrm{L}}$, lvisc \\
\hline ISMIO Frit 202 & 59 & $\mathrm{~T}_{\mathrm{L}}$, lvisc \\
\hline ISMIO Frit 202 & 60 & $\mathrm{~T}_{\mathrm{L}}$, lvisc \\
\hline
\end{tabular}


Table A.2. Various Property Predictions for the Frit 418 - SB2/3 System (Baseline and Secondary Streams)

\begin{tabular}{|c|c|c|c|c|c|c|c|c|c|}
\hline Glass System & $\begin{array}{l}\text { WL } \\
(\%)\end{array}$ & $\begin{array}{c}\text { B Del Gp } \\
\text { Value }\end{array}$ & $\begin{array}{c}\text { TL Pred } \\
\left({ }^{\circ} \mathrm{C}\right)\end{array}$ & $\begin{array}{c}\text { Visc Pred } \\
\text { (P) }\end{array}$ & $\begin{array}{c}\text { Al2O3 } \\
\text { wt \% }\end{array}$ & $\begin{array}{l}\text { Ti2O } \\
\text { wt\% }\end{array}$ & $\begin{array}{c}\text { Na2SO4 } \\
\text { wt } \%\end{array}$ & $\begin{array}{l}\text { R2O } \\
\text { wt\% }\end{array}$ & R2O MAR \\
\hline MST Baseline Frit 202 & 25 & -9.0326 & 833.88 & 106.14 & 3.66 & 0.8942 & 0.02 & 15.77 & 18.64 \\
\hline MST Baseline Frit 202 & 26 & -9.1097 & 846.61 & 102.01 & 3.81 & 0.9300 & 0.03 & 15.88 & 18.64 \\
\hline MST Baseline Frit 202 & 27 & -9.1867 & 858.97 & 97.94 & 3.95 & 0.9658 & 0.03 & 15.99 & 18.64 \\
\hline MST Baseline Frit 202 & 28 & -9.2638 & 870.93 & 93.93 & 4.10 & 1.0015 & 0.03 & 16.10 & 18.64 \\
\hline MST Baseline Frit 202 & 29 & -9.3409 & 882.59 & 89.98 & 4.25 & 1.0373 & 0.03 & 16.22 & 18.64 \\
\hline MST Baseline Frit 202 & 30 & -9.4179 & 893.93 & 86.10 & 4.39 & 1.0731 & 0.03 & 16.33 & 18.64 \\
\hline MST Baseline Frit 202 & 31 & -9.4950 & 904.95 & 82.29 & 4.54 & 1.1089 & 0.03 & 16.44 & 18.64 \\
\hline MST Baseline Frit 202 & 32 & -9.5721 & 915.64 & 78.55 & 4.69 & 1.1446 & 0.03 & 16.55 & 18.64 \\
\hline MST Baseline Frit 202 & 33 & -9.6491 & 926.07 & 74.88 & 4.83 & 1.1804 & 0.03 & 16.66 & 18.64 \\
\hline MST Baseline Frit 202 & 34 & -9.7262 & 936.24 & 71.28 & 4.98 & 1.2162 & 0.03 & 16.77 & 18.64 \\
\hline MST Baseline Frit 202 & 35 & -9.8033 & 946.14 & 67.75 & 5.13 & 1.2519 & 0.03 & 16.88 & 18.64 \\
\hline MST Baseline Frit 202 & 36 & -9.8803 & 955.76 & 64.31 & 5.27 & 1.2877 & 0.04 & 16.99 & 18.64 \\
\hline MST Baseline Frit 202 & 37 & -9.9574 & 965.17 & 60.94 & 5.42 & 1.3235 & 0.04 & 17.10 & 18.64 \\
\hline MST Baseline Frit 202 & 38 & -10.0345 & 974.34 & 57.66 & 5.57 & 1.3592 & 0.04 & 17.21 & 18.64 \\
\hline MST Baseline Frit 202 & 39 & -10.1115 & 983.29 & 54.46 & 5.71 & 1.3950 & 0.04 & 17.32 & 18.64 \\
\hline MST Baseline Frit 202 & 40 & -10.1886 & 991.98 & 51.34 & 5.86 & 1.4308 & 0.04 & 17.44 & 18.64 \\
\hline MST Baseline Frit 202 & 41 & -10.2656 & 1000.51 & 48.31 & 6.01 & 1.4666 & 0.04 & 17.55 & 18.64 \\
\hline MST Baseline Frit 202 & 42 & -10.3427 & 1008.83 & 45.37 & 6.15 & 1.5023 & 0.04 & 17.66 & 18.64 \\
\hline MST Baseline Frit 202 & 43 & -10.4197 & 1016.93 & 42.52 & 6.30 & 1.5381 & 0.04 & 17.77 & 18.64 \\
\hline MST Baseline Frit 202 & 44 & -10.4968 & 1024.87 & 39.77 & 6.44 & 1.5739 & 0.04 & 17.88 & 18.64 \\
\hline MST Baseline Frit 202 & 45 & -10.5738 & 1032.63 & 37.10 & 6.59 & 1.6096 & 0.04 & 17.99 & 18.64 \\
\hline MST Baseline Frit 202 & 46 & -10.6509 & 1040.22 & 34.54 & 6.74 & 1.6454 & 0.04 & 18.10 & 18.64 \\
\hline MST Baseline Frit 202 & 47 & -10.7280 & 1047.60 & 32.06 & 6.88 & 1.6812 & 0.05 & 18.21 & 18.63 \\
\hline
\end{tabular}


Table A.2. Various Property Predictions for the Frit 418 - SB2/3 System (Baseline and Secondary Streams)

\begin{tabular}{|c|c|c|c|c|c|c|c|c|c|}
\hline Glass System & $\begin{array}{l}\text { WL } \\
(\%)\end{array}$ & $\begin{array}{c}\text { B Del Gp } \\
\text { Value }\end{array}$ & $\begin{array}{c}\text { TL Pred } \\
\left({ }^{\circ} \mathrm{C}\right)\end{array}$ & $\begin{array}{c}\text { Visc Pred } \\
\text { (P) } \\
\end{array}$ & $\begin{array}{c}\text { Al2O3 } \\
\text { wt \% }\end{array}$ & $\begin{array}{l}\text { Ti2O } \\
\text { wt\% } \\
\end{array}$ & $\begin{array}{c}\text { Na2SO4 } \\
\text { wt } \% \\
\end{array}$ & $\begin{array}{l}\text { R2O } \\
\text { wt \% } \\
\end{array}$ & R2O MAR \\
\hline MST Baseline Frit 202 & 48 & -10.8051 & 1054.86 & 29.69 & 7.03 & 1.7169 & 0.05 & 18.32 & 18.63 \\
\hline MST Baseline Frit 202 & 49 & -10.8821 & 1061.96 & 27.41 & 7.18 & 1.7527 & 0.05 & 18.43 & 18.62 \\
\hline MST Baseline Frit 202 & 50 & -10.9592 & 1068.90 & 25.24 & 7.32 & 1.7885 & 0.05 & 18.54 & 18.62 \\
\hline MST Baseline Frit 202 & 51 & -11.0363 & 1075.67 & 23.16 & 7.47 & 1.8242 & 0.05 & 18.66 & 18.61 \\
\hline MST Baseline Frit 202 & 52 & -11.1133 & 1082.33 & 21.18 & 7.62 & 1.8600 & 0.05 & 18.77 & 18.61 \\
\hline MST Baseline Frit 202 & 53 & -11.1904 & 1088.84 & 19.31 & 7.76 & 1.8958 & 0.05 & 18.88 & 18.61 \\
\hline MST Baseline Frit 202 & 54 & -11.2675 & 1095.19 & 17.53 & 7.91 & 1.9316 & 0.05 & 18.99 & 18.60 \\
\hline MST Baseline Frit 202 & 55 & -11.3446 & 1101.45 & 15.85 & 8.06 & 1.9673 & 0.05 & 19.10 & 18.60 \\
\hline MST Baseline Frit 202 & 56 & -11.4216 & 1107.57 & 14.28 & 8.20 & 2.0031 & 0.05 & 19.21 & 18.59 \\
\hline MST Baseline Frit 202 & 57 & -11.4985 & 1113.58 & 12.80 & 8.35 & 2.0389 & 0.06 & 19.32 & 18.59 \\
\hline MST Baseline Frit 202 & 58 & -11.5756 & 1119.44 & 11.42 & 8.50 & 2.0746 & 0.06 & 19.43 & 18.58 \\
\hline MST Baseline Frit 202 & 59 & -11.6527 & 1125.21 & 10.14 & 8.64 & 2.1104 & 0.06 & 19.54 & 18.58 \\
\hline MST Baseline Frit 202 & 60 & -11.7298 & 1130.87 & 8.95 & 8.79 & 2.1462 & 0.06 & 19.65 & 18.57 \\
\hline MST Optimized Frit 202 & 25 & -9.1792 & 837.00 & 105.24 & 3.78 & 0.2399 & 0.03 & 15.84 & 18.64 \\
\hline MST Optimized Frit 202 & 26 & -9.2621 & 850.09 & 101.11 & 3.93 & 0.2495 & 0.03 & 15.95 & 18.64 \\
\hline MST Optimized Frit 202 & 27 & -9.3450 & 862.84 & 97.03 & 4.08 & 0.2591 & 0.03 & 16.06 & 18.64 \\
\hline MST Optimized Frit 202 & 28 & -9.4280 & 875.19 & 93.02 & 4.23 & 0.2687 & 0.03 & 16.18 & 18.64 \\
\hline MST Optimized Frit 202 & 29 & -9.5109 & 887.25 & 89.07 & 4.39 & 0.2783 & 0.03 & 16.29 & 18.64 \\
\hline MST Optimized Frit 202 & 30 & -9.5938 & 898.95 & 85.19 & 4.54 & 0.2879 & 0.03 & 16.40 & 18.64 \\
\hline MST Optimized Frit 202 & 31 & -9.6768 & 910.38 & 81.38 & 4.69 & 0.2975 & 0.03 & 16.52 & 18.64 \\
\hline MST Optimized Frit 202 & 32 & -9.7596 & 921.48 & 77.64 & 4.84 & 0.3071 & 0.03 & 16.63 & 18.64 \\
\hline MST Optimized Frit 202 & 33 & -9.8426 & 932.32 & 73.97 & 4.99 & 0.3167 & 0.03 & 16.74 & 18.64 \\
\hline MST Optimized Frit 202 & 34 & -9.9255 & 942.86 & 70.38 & 5.14 & 0.3263 & 0.03 & 16.86 & 18.64 \\
\hline
\end{tabular}


Table A.2. Various Property Predictions for the Frit 418 - SB2/3 System (Baseline and Secondary Streams)

\begin{tabular}{|c|c|c|c|c|c|c|c|c|c|}
\hline Glass System & $\begin{array}{l}\text { WL } \\
(\%)\end{array}$ & $\begin{array}{c}\text { B Del Gp } \\
\text { Value }\end{array}$ & $\begin{array}{c}\text { TL Pred } \\
\left({ }^{\circ} \mathrm{C}\right)\end{array}$ & $\begin{array}{c}\text { Visc Pred } \\
\text { (P) }\end{array}$ & $\begin{array}{c}\text { Al2O3 } \\
\text { wt } \%\end{array}$ & $\begin{array}{l}\text { Ti2O } \\
\text { wt } \%\end{array}$ & $\begin{array}{c}\text { Na2SO4 } \\
\text { wt } \% \\
\end{array}$ & $\begin{array}{l}\text { R2O } \\
\text { wt\% } \\
\end{array}$ & R2O MAR \\
\hline MST Optimized Frit 202 & 35 & -10.0084 & 953.17 & 66.86 & 5.29 & 0.3359 & 0.04 & 16.97 & 18.64 \\
\hline MST Optimized Frit 202 & 36 & -10.0913 & 963.19 & 63.43 & 5.44 & 0.3455 & 0.04 & 17.08 & 18.64 \\
\hline MST Optimized Frit 202 & 37 & -10.1743 & 973.01 & 60.07 & 5.60 & 0.3551 & 0.04 & 17.20 & 18.64 \\
\hline MST Optimized Frit 202 & 38 & -10.2572 & 982.55 & 56.80 & 5.75 & 0.3647 & 0.04 & 17.31 & 18.64 \\
\hline MST Optimized Frit 202 & 39 & -10.3401 & 991.88 & 53.62 & 5.90 & 0.3743 & 0.04 & 17.42 & 18.64 \\
\hline MST Optimized Frit 202 & 40 & -10.4231 & 1001.01 & 50.52 & 6.05 & 0.3839 & 0.04 & 17.54 & 18.64 \\
\hline MST Optimized Frit 202 & 41 & -10.5060 & 1009.91 & 47.51 & 6.20 & 0.3935 & 0.04 & 17.65 & 18.64 \\
\hline MST Optimized Frit 202 & 42 & -10.5890 & 1018.64 & 44.59 & 6.35 & 0.4031 & 0.04 & 17.76 & 18.64 \\
\hline MST Optimized Frit 202 & 43 & -10.6719 & 1027.14 & 41.76 & 6.50 & 0.4127 & 0.04 & 17.88 & 18.64 \\
\hline MST Optimized Frit 202 & 44 & -10.7547 & 1035.48 & 39.03 & 6.65 & 0.4223 & 0.04 & 17.99 & 18.64 \\
\hline MST Optimized Frit 202 & 45 & -10.8376 & 1043.61 & 36.39 & 6.81 & 0.4319 & 0.05 & 18.11 & 18.64 \\
\hline MST Optimized Frit 202 & 46 & -10.9206 & 1051.60 & 33.85 & 6.96 & 0.4415 & 0.05 & 18.22 & 18.63 \\
\hline MST Optimized Frit 202 & 47 & -11.0035 & 1059.39 & 31.40 & 7.11 & 0.4511 & 0.05 & 18.33 & 18.63 \\
\hline MST Optimized Frit 202 & 48 & -11.0864 & 1067.03 & 29.05 & 7.26 & 0.4607 & 0.05 & 18.45 & 18.62 \\
\hline MST Optimized Frit 202 & 49 & -11.1692 & 1074.49 & 26.81 & 7.41 & 0.4703 & 0.05 & 18.56 & 18.62 \\
\hline MST Optimized Frit 202 & 50 & -11.2522 & 1081.83 & 24.66 & 7.56 & 0.4799 & 0.05 & 18.67 & 18.61 \\
\hline MST Optimized Frit 202 & 51 & -11.3352 & 1088.99 & 22.61 & 7.71 & 0.4895 & 0.05 & 18.79 & 18.61 \\
\hline MST Optimized Frit 202 & 52 & -11.4181 & 1096.02 & 20.66 & 7.86 & 0.4991 & 0.05 & 18.90 & 18.60 \\
\hline MST Optimized Frit 202 & 53 & -11.5011 & 1102.90 & 18.82 & 8.02 & 0.5087 & 0.05 & 19.01 & 18.60 \\
\hline MST Optimized Frit 202 & 54 & -11.5839 & 1109.66 & 17.07 & 8.17 & 0.5183 & 0.05 & 19.13 & 18.60 \\
\hline MST Optimized Frit 202 & 55 & -11.6668 & 1116.27 & 15.42 & 8.32 & 0.5279 & 0.06 & 19.24 & 18.59 \\
\hline MST Optimized Frit 202 & 56 & -11.7498 & 1122.76 & 13.88 & 8.47 & 0.5375 & 0.06 & 19.35 & 18.59 \\
\hline MST Optimized Frit 202 & 57 & -11.8327 & 1129.11 & 12.43 & 8.62 & 0.5471 & 0.06 & 19.47 & 18.58 \\
\hline
\end{tabular}


Table A.2. Various Property Predictions for the Frit 418 - SB2/3 System (Baseline and Secondary Streams)

\begin{tabular}{|c|c|c|c|c|c|c|c|c|c|}
\hline Glass System & $\begin{array}{l}\text { WL } \\
(\%)\end{array}$ & $\begin{array}{c}\text { B Del Gp } \\
\text { Value }\end{array}$ & $\begin{array}{c}\text { TL Pred } \\
\left({ }^{\circ} \mathrm{C}\right)\end{array}$ & $\begin{array}{c}\text { Visc Pred } \\
\text { (P) }\end{array}$ & $\begin{array}{c}\text { Al2O3 } \\
\text { wt } \%\end{array}$ & $\begin{array}{l}\text { Ti2O } \\
\text { wt\% } \\
\end{array}$ & $\begin{array}{c}\text { Na2SO4 } \\
\text { wt } \% \\
\end{array}$ & $\begin{array}{l}\text { R2O } \\
\text { wt \% } \\
\end{array}$ & R2O MAR \\
\hline MST Optimized Frit 202 & 58 & -11.9156 & 1135.34 & 11.08 & 8.77 & 0.5566 & 0.06 & 19.58 & 18.58 \\
\hline MST Optimized Frit 202 & 59 & -11.9986 & 1141.48 & 9.83 & 8.92 & 0.5662 & 0.06 & 19.69 & 18.57 \\
\hline MST Optimized Frit 202 & 60 & -12.0815 & 1147.48 & 8.67 & 9.07 & 0.5758 & 0.06 & 19.81 & 18.57 \\
\hline Engr MST Case A Frit 202 & 25 & -9.0471 & 838.78 & 106.58 & 3.74 & 0.5169 & 0.02 & 15.73 & 18.64 \\
\hline Engr MST Case A Frit 202 & 26 & -9.1248 & 851.81 & 102.45 & 3.89 & 0.5376 & 0.03 & 15.84 & 18.64 \\
\hline Engr MST Case A Frit 202 & 27 & -9.2025 & 864.50 & 98.39 & 4.04 & 0.5582 & 0.03 & 15.95 & 18.64 \\
\hline Engr MST Case A Frit 202 & 28 & -9.2800 & 876.79 & 94.39 & 4.19 & 0.5789 & 0.03 & 16.06 & 18.64 \\
\hline Engr MST Case A Frit 202 & 29 & -9.3576 & 888.76 & 90.45 & 4.34 & 0.5996 & 0.03 & 16.17 & 18.64 \\
\hline Engr MST Case A Frit 202 & 30 & -9.4353 & 900.39 & 86.57 & 4.49 & 0.6203 & 0.03 & 16.28 & 18.64 \\
\hline Engr MST Case A Frit 202 & 31 & -9.5129 & 911.74 & 82.76 & 4.64 & 0.6409 & 0.03 & 16.39 & 18.64 \\
\hline Engr MST Case A Frit 202 & 32 & -9.5906 & 922.76 & 79.02 & 4.79 & 0.6616 & 0.03 & 16.50 & 18.64 \\
\hline Engr MST Case A Frit 202 & 33 & -9.6683 & 933.50 & 75.34 & 4.94 & 0.6823 & 0.03 & 16.61 & 18.64 \\
\hline Engr MST Case A Frit 202 & 34 & -9.7458 & 943.96 & 71.75 & 5.09 & 0.7030 & 0.03 & 16.72 & 18.64 \\
\hline Engr MST Case A Frit 202 & 35 & -9.8235 & 954.19 & 68.22 & 5.24 & 0.7236 & 0.03 & 16.83 & 18.64 \\
\hline Engr MST Case A Frit 202 & 36 & -9.9012 & 964.13 & 64.77 & 5.39 & 0.7443 & 0.04 & 16.93 & 18.64 \\
\hline Engr MST Case A Frit 202 & 37 & -9.9788 & 973.83 & 61.40 & 5.54 & 0.7650 & 0.04 & 17.04 & 18.64 \\
\hline Engr MST Case A Frit 202 & 38 & -10.0565 & 983.29 & 58.11 & 5.69 & 0.7857 & 0.04 & 17.15 & 18.64 \\
\hline Engr MST Case A Frit 202 & 39 & -10.1341 & 992.57 & 54.91 & 5.84 & 0.8064 & 0.04 & 17.26 & 18.64 \\
\hline Engr MST Case A Frit 202 & 40 & -10.2117 & 1001.59 & 51.79 & 5.99 & 0.8270 & 0.04 & 17.37 & 18.64 \\
\hline Engr MST Case A Frit 202 & 41 & -10.2894 & 1010.40 & 48.75 & 6.14 & 0.8477 & 0.04 & 17.48 & 18.64 \\
\hline Engr MST Case A Frit 202 & 42 & -10.3670 & 1019.00 & 45.80 & 6.29 & 0.8684 & 0.04 & 17.59 & 18.64 \\
\hline Engr MST Case A Frit 202 & 43 & -10.4446 & 1027.45 & 42.95 & 6.44 & 0.8891 & 0.04 & 17.70 & 18.64 \\
\hline Engr MST Case A Frit 202 & 44 & -10.5223 & 1035.67 & 40.18 & 6.59 & 0.9097 & 0.04 & 17.81 & 18.64 \\
\hline
\end{tabular}


Table A.2. Various Property Predictions for the Frit 418 - SB2/3 System (Baseline and Secondary Streams)

\begin{tabular}{|c|c|c|c|c|c|c|c|c|c|}
\hline Glass System & $\begin{array}{l}\text { WL } \\
(\%)\end{array}$ & $\begin{array}{c}\text { B Del Gp } \\
\text { Value }\end{array}$ & $\begin{array}{c}\text { TL Pred } \\
\left({ }^{\circ} \mathrm{C}\right)\end{array}$ & $\begin{array}{c}\text { Visc Pred } \\
\text { (P) } \\
\end{array}$ & $\begin{array}{c}\text { Al2O3 } \\
\text { wt \% }\end{array}$ & $\begin{array}{l}\text { Ti2O } \\
\text { wt\% } \\
\end{array}$ & $\begin{array}{c}\text { Na2SO4 } \\
\text { wt } \% \\
\end{array}$ & $\begin{array}{l}\text { R2O } \\
\text { wt \% } \\
\end{array}$ & R2O MAR \\
\hline Engr MST Case A Frit 202 & 45 & -10.6000 & 1043.71 & 37.51 & 6.74 & 0.9304 & 0.04 & 17.92 & 18.64 \\
\hline Engr MST Case A Frit 202 & 46 & -10.6775 & 1051.58 & 34.93 & 6.89 & 0.9511 & 0.05 & 18.03 & 18.64 \\
\hline Engr MST Case A Frit 202 & 47 & -10.7552 & 1059.31 & 32.44 & 7.04 & 0.9718 & 0.05 & 18.14 & 18.64 \\
\hline Engr MST Case A Frit 202 & 48 & -10.8329 & 1066.83 & 30.06 & 7.19 & 0.9924 & 0.05 & 18.25 & 18.63 \\
\hline Engr MST Case A Frit 202 & 49 & -10.9105 & 1074.20 & 27.77 & 7.34 & 1.0131 & 0.05 & 18.36 & 18.63 \\
\hline Engr MST Case A Frit 202 & 50 & -10.9881 & 1081.41 & 25.58 & 7.49 & 1.0338 & 0.05 & 18.47 & 18.62 \\
\hline Engr MST Case A Frit 202 & 51 & -11.0658 & 1088.51 & 23.49 & 7.64 & 1.0545 & 0.05 & 18.57 & 18.62 \\
\hline Engr MST Case A Frit 202 & 52 & -11.1434 & 1095.43 & 21.50 & 7.79 & 1.0751 & 0.05 & 18.68 & 18.61 \\
\hline Engr MST Case A Frit 202 & 53 & -11.2210 & 1102.21 & 19.61 & 7.94 & 1.0958 & 0.05 & 18.79 & 18.61 \\
\hline Engr MST Case A Frit 202 & 54 & -11.2986 & 1108.85 & 17.81 & 8.09 & 1.1165 & 0.05 & 18.90 & 18.60 \\
\hline Engr MST Case A Frit 202 & 55 & -11.3763 & 1115.39 & 16.12 & 8.24 & 1.1372 & 0.05 & 19.01 & 18.60 \\
\hline Engr MST Case A Frit 202 & 56 & -11.4540 & 1121.77 & 14.53 & 8.39 & 1.1578 & 0.06 & 19.12 & 18.59 \\
\hline Engr MST Case A Frit 202 & 57 & -11.5316 & 1128.02 & 13.04 & 8.54 & 1.1785 & 0.06 & 19.23 & 18.59 \\
\hline Engr MST Case A Frit 202 & 58 & -11.6092 & 1134.17 & 11.65 & 8.69 & 1.1992 & 0.06 & 19.34 & 18.59 \\
\hline Engr MST Case A Frit 202 & 59 & -11.6869 & 1140.21 & 10.35 & 8.84 & 1.2199 & 0.06 & 19.45 & 18.58 \\
\hline Engr MST Case A Frit 202 & 60 & -11.7644 & 1146.12 & 9.14 & 8.99 & 1.2405 & 0.06 & 19.56 & 18.58 \\
\hline Engr MST Case B Frit 202 & 25 & -7.5474 & 872.91 & 143.46 & 6.31 & 0.3104 & 0.02 & 15.05 & 18.64 \\
\hline Engr MST Case B Frit 202 & 26 & -7.5652 & 886.04 & 140.11 & 6.56 & 0.3228 & 0.02 & 15.13 & 18.64 \\
\hline Engr MST Case B Frit 202 & 27 & -7.5828 & 898.80 & 136.76 & 6.81 & 0.3353 & 0.02 & 15.21 & 18.64 \\
\hline Engr MST Case B Frit 202 & 28 & -7.6003 & 911.11 & 133.40 & 7.07 & 0.3477 & 0.02 & 15.29 & 18.64 \\
\hline Engr MST Case B Frit 202 & 29 & -7.6180 & 923.07 & 130.03 & 7.32 & 0.3601 & 0.03 & 15.38 & 18.64 \\
\hline Engr MST Case B Frit 202 & 30 & -7.6357 & 934.67 & 126.67 & 7.57 & 0.3725 & 0.03 & 15.46 & 18.64 \\
\hline Engr MST Case B Frit 202 & 31 & -7.6534 & 945.88 & 123.30 & 7.82 & 0.3849 & 0.03 & 15.54 & 18.64 \\
\hline
\end{tabular}


Table A.2. Various Property Predictions for the Frit 418 - SB2/3 System (Baseline and Secondary Streams)

\begin{tabular}{|c|c|c|c|c|c|c|c|c|c|}
\hline Glass System & $\begin{array}{l}\text { WL } \\
(\%)\end{array}$ & $\begin{array}{c}\text { B Del Gp } \\
\text { Value }\end{array}$ & $\begin{array}{c}\text { TL Pred } \\
\left({ }^{\circ} \mathrm{C}\right)\end{array}$ & $\begin{array}{l}\text { Visc Pred } \\
\text { (P) }\end{array}$ & $\begin{array}{c}\text { Al2O3 } \\
\text { wt \% }\end{array}$ & $\begin{array}{l}\text { Ti2O } \\
\text { wt } \%\end{array}$ & $\begin{array}{c}\text { Na2SO4 } \\
\text { wt } \%\end{array}$ & $\begin{array}{l}\text { R2O } \\
\text { wt \% }\end{array}$ & R2O MAR \\
\hline Engr MST Case B Frit 202 & 32 & -7.6710 & 956.79 & 119.93 & 8.08 & 0.3973 & 0.03 & 15.62 & 18.64 \\
\hline Engr MST Case B Frit 202 & 33 & -7.6887 & 967.34 & 116.56 & 8.33 & 0.4098 & 0.03 & 15.70 & 18.64 \\
\hline Engr MST Case B Frit 202 & 34 & -7.7063 & 977.63 & 113.19 & 8.58 & 0.4222 & 0.03 & 15.79 & 18.64 \\
\hline Engr MST Case B Frit 202 & 35 & -7.7240 & 987.61 & 109.82 & 8.83 & 0.4346 & 0.03 & 15.87 & 18.64 \\
\hline Engr MST Case B Frit 202 & 36 & -7.7415 & 997.28 & 106.46 & 9.09 & 0.4470 & 0.03 & 15.95 & 18.64 \\
\hline Engr MST Case B Frit 202 & 37 & -7.7592 & 1006.71 & 103.10 & 9.34 & 0.4594 & 0.03 & 16.03 & 18.64 \\
\hline Engr MST Case B Frit 202 & 38 & -7.7769 & 1015.85 & 99.76 & 9.59 & 0.4718 & 0.03 & 16.11 & 18.64 \\
\hline Engr MST Case B Frit 202 & 39 & -7.7945 & 1024.77 & 96.42 & 9.84 & 0.4843 & 0.03 & 16.20 & 18.64 \\
\hline Engr MST Case B Frit 202 & 40 & -7.8122 & 1033.45 & 93.09 & 10.09 & 0.4967 & 0.04 & 16.28 & 18.64 \\
\hline Engr MST Case B Frit 202 & 41 & -7.8299 & 1041.87 & 89.78 & 10.35 & 0.5091 & 0.04 & 16.36 & 18.64 \\
\hline Engr MST Case B Frit 202 & 42 & -7.8475 & 1050.10 & 86.48 & 10.60 & 0.5215 & 0.04 & 16.44 & 18.64 \\
\hline Engr MST Case B Frit 202 & 43 & -7.8651 & 1058.08 & 83.20 & 10.85 & 0.5339 & 0.04 & 16.52 & 18.64 \\
\hline Engr MST Case B Frit 202 & 44 & -7.8829 & 1065.89 & 79.94 & 11.10 & 0.5463 & 0.04 & 16.61 & 18.64 \\
\hline Engr MST Case B Frit 202 & 45 & -7.9005 & 1073.47 & 76.70 & 11.36 & 0.5588 & 0.04 & 16.69 & 18.64 \\
\hline Engr MST Case B Frit 202 & 46 & -7.9181 & 1080.88 & 73.49 & 11.61 & 0.5712 & 0.04 & 16.77 & 18.64 \\
\hline Engr MST Case B Frit 202 & 47 & -7.9358 & 1088.11 & 70.30 & 11.86 & 0.5836 & 0.04 & 16.85 & 18.64 \\
\hline Engr MST Case B Frit 202 & 48 & -7.9534 & 1095.14 & 67.15 & 12.11 & 0.5960 & 0.04 & 16.93 & 18.64 \\
\hline Engr MST Case B Frit 202 & 49 & -7.9710 & 1102.02 & 64.03 & 12.37 & 0.6084 & 0.04 & 17.02 & 18.64 \\
\hline Engr MST Case B Frit 202 & 50 & -7.9888 & 1108.71 & 60.94 & 12.62 & 0.6208 & 0.04 & 17.10 & 18.64 \\
\hline Engr MST Case B Frit 202 & 51 & -8.0064 & 1115.26 & 57.89 & 12.87 & 0.6333 & 0.05 & 17.18 & 18.64 \\
\hline Engr MST Case B Frit 202 & 52 & -8.0240 & 1121.67 & 54.89 & 13.12 & 0.6457 & 0.05 & 17.26 & 18.64 \\
\hline Engr MST Case B Frit 202 & 53 & -8.0417 & 1127.89 & 51.93 & 13.38 & 0.6581 & 0.05 & 17.34 & 18.64 \\
\hline Engr MST Case B Frit 202 & 54 & -8.0593 & 1134.00 & 49.02 & 13.63 & 0.6705 & 0.05 & 17.42 & 18.64 \\
\hline
\end{tabular}


Table A.2. Various Property Predictions for the Frit 418 - SB2/3 System (Baseline and Secondary Streams)

\begin{tabular}{|c|c|c|c|c|c|c|c|c|c|}
\hline Glass System & $\begin{array}{l}\text { WL } \\
(\%)\end{array}$ & $\begin{array}{c}\text { B Del Gp } \\
\text { Value }\end{array}$ & $\begin{array}{c}\text { TL Pred } \\
\left({ }^{\circ} \mathrm{C}\right)\end{array}$ & $\begin{array}{c}\text { Visc Pred } \\
\text { (P) }\end{array}$ & $\begin{array}{c}\text { Al2O3 } \\
\text { wt } \%\end{array}$ & $\begin{array}{l}\text { Ti2O } \\
\text { wt\% } \\
\end{array}$ & $\begin{array}{c}\text { Na2SO4 } \\
\text { wt } \% \\
\end{array}$ & $\begin{array}{l}\text { R2O } \\
\text { wt\% } \\
\end{array}$ & R2O MAR \\
\hline Engr MST Case B Frit 202 & 55 & -8.0770 & 1139.94 & 46.16 & 13.88 & 0.6829 & 0.05 & 17.51 & 18.64 \\
\hline Engr MST Case B Frit 202 & 56 & -8.0946 & 1145.78 & 43.36 & 14.13 & 0.6953 & 0.05 & 17.59 & 18.64 \\
\hline Engr MST Case B Frit 202 & 57 & -8.1123 & 1151.49 & 40.62 & 14.38 & 0.7078 & 0.05 & 17.67 & 18.64 \\
\hline Engr MST Case B Frit 202 & 58 & -8.1299 & 1157.03 & 37.94 & 14.64 & 0.7202 & 0.05 & 17.75 & 18.64 \\
\hline Engr MST Case B Frit 202 & 59 & -8.1476 & 1162.49 & 35.33 & 14.89 & 0.7326 & 0.05 & 17.83 & 18.64 \\
\hline Engr MST Case B Frit 202 & 60 & -8.1652 & 1167.80 & 32.79 & 15.14 & 0.7450 & 0.05 & 17.92 & 18.64 \\
\hline ISMIO Frit 202 & 25 & -9.0829 & 846.30 & 104.10 & 3.73 & 0.0059 & 0.08 & 15.71 & 18.64 \\
\hline ISMIO Frit 202 & 26 & -9.1621 & 859.70 & 99.95 & 3.88 & 0.0061 & 0.09 & 15.82 & 18.64 \\
\hline ISMIO Frit 202 & 27 & -9.2411 & 872.73 & 95.86 & 4.03 & 0.0064 & 0.09 & 15.93 & 18.64 \\
\hline ISMIO Frit 202 & 28 & -9.3202 & 885.40 & 91.84 & 4.18 & 0.0066 & 0.09 & 16.03 & 18.64 \\
\hline ISMIO Frit 202 & 29 & -9.3994 & 897.73 & 87.89 & 4.33 & 0.0069 & 0.10 & 16.14 & 18.64 \\
\hline ISMIO Frit 202 & 30 & -9.4783 & 909.77 & 84.00 & 4.48 & 0.0071 & 0.10 & 16.25 & 18.64 \\
\hline ISMIO Frit 202 & 31 & -9.5574 & 921.46 & 80.19 & 4.63 & 0.0073 & 0.10 & 16.36 & 18.64 \\
\hline ISMIO Frit 202 & 32 & -9.6365 & 932.85 & 76.45 & 4.77 & 0.0076 & 0.11 & 16.47 & 18.64 \\
\hline ISMIO Frit 202 & 33 & -9.7156 & 943.95 & 72.79 & 4.92 & 0.0078 & 0.11 & 16.58 & 18.64 \\
\hline ISMIO Frit 202 & 34 & -9.7946 & 954.78 & 69.20 & 5.07 & 0.0080 & 0.11 & 16.68 & 18.64 \\
\hline ISMIO Frit 202 & 35 & -9.8737 & 965.34 & 65.70 & 5.22 & 0.0083 & 0.11 & 16.79 & 18.64 \\
\hline ISMIO Frit 202 & 36 & -9.9528 & 975.68 & 62.27 & 5.37 & 0.0085 & 0.12 & 16.90 & 18.64 \\
\hline ISMIO Frit 202 & 37 & -10.0319 & 985.73 & 58.93 & 5.52 & 0.0087 & 0.12 & 17.01 & 18.64 \\
\hline ISMIO Frit 202 & 38 & -10.1110 & 995.56 & 55.68 & 5.67 & 0.0090 & 0.12 & 17.12 & 18.64 \\
\hline ISMIO Frit 202 & 39 & -10.1900 & 1005.15 & 52.51 & 5.82 & 0.0092 & 0.13 & 17.23 & 18.64 \\
\hline ISMIO Frit 202 & 40 & -10.2691 & 1014.52 & 49.43 & 5.97 & 0.0095 & 0.13 & 17.33 & 18.64 \\
\hline ISMIO Frit 202 & 41 & -10.3481 & 1023.68 & 46.44 & 6.12 & 0.0097 & 0.13 & 17.44 & 18.64 \\
\hline
\end{tabular}


Table A.2. Various Property Predictions for the Frit 418 - SB2/3 System (Baseline and Secondary Streams)

\begin{tabular}{|c|c|c|c|c|c|c|c|c|c|}
\hline Glass System & $\begin{array}{l}\text { WL } \\
(\%)\end{array}$ & $\begin{array}{c}\text { B Del Gp } \\
\text { Value }\end{array}$ & $\begin{array}{c}\begin{array}{c}\text { TL Pred } \\
\left({ }^{\circ} \mathrm{C}\right)\end{array} \\
\end{array}$ & $\begin{array}{c}\text { Visc Pred } \\
\text { (P) }\end{array}$ & $\begin{array}{c}\text { Al2O3 } \\
\text { wt } \%\end{array}$ & $\begin{array}{l}\text { Ti2O } \\
\text { wt } \% \\
\end{array}$ & $\begin{array}{c}\text { Na2SO4 } \\
\text { wt } \%\end{array}$ & $\begin{array}{l}\text { R2O } \\
\text { wt\% } \\
\end{array}$ & R2O MAR \\
\hline ISMIO Frit 202 & 42 & -10.4272 & 1032.63 & 43.55 & 6.27 & 0.0099 & 0.14 & 17.55 & 18.64 \\
\hline ISMIO Frit 202 & 43 & -10.5064 & 1041.42 & 40.75 & 6.42 & 0.0102 & 0.14 & 17.66 & 18.64 \\
\hline ISMIO Frit 202 & 44 & -10.5854 & 1049.98 & 38.04 & 6.56 & 0.0104 & 0.14 & 17.77 & 18.64 \\
\hline ISMIO Frit 202 & 45 & -10.6645 & 1058.36 & 35.43 & 6.71 & 0.0106 & 0.15 & 17.88 & 18.64 \\
\hline ISMIO Frit 202 & 46 & -10.7436 & 1066.56 & 32.92 & 6.86 & 0.0109 & 0.15 & 17.98 & 18.64 \\
\hline ISMIO Frit 202 & 47 & -10.8226 & 1074.59 & 30.51 & 7.01 & 0.0111 & 0.15 & 18.09 & 18.64 \\
\hline ISMIO Frit 202 & 48 & -10.9017 & 1082.44 & 28.19 & 7.16 & 0.0113 & 0.16 & 18.20 & 18.63 \\
\hline ISMIO Frit 202 & 49 & -10.9807 & 1090.17 & 25.98 & 7.31 & 0.0116 & 0.16 & 18.31 & 18.63 \\
\hline ISMIO Frit 202 & 50 & -11.0599 & 1097.71 & 23.87 & 7.46 & 0.0118 & 0.16 & 18.42 & 18.62 \\
\hline ISMIO Frit 202 & 51 & -11.1389 & 1105.09 & 21.86 & 7.61 & 0.0120 & 0.17 & 18.53 & 18.62 \\
\hline ISMIO Frit 202 & 52 & -11.2180 & 1112.33 & 19.95 & 7.76 & 0.0123 & 0.17 & 18.63 & 18.61 \\
\hline ISMIO Frit 202 & 53 & -11.2971 & 1119.42 & 18.14 & 7.91 & 0.0125 & 0.17 & 18.74 & 18.61 \\
\hline ISMIO Frit 202 & 54 & -11.3762 & 1126.38 & 16.43 & 8.06 & 0.0128 & 0.18 & 18.85 & 18.61 \\
\hline ISMIO Frit 202 & 55 & -11.4551 & 1133.20 & 14.82 & 8.21 & 0.0130 & 0.18 & 18.96 & 18.60 \\
\hline ISMIO Frit 202 & 56 & -11.5343 & 1139.91 & 13.31 & 8.35 & 0.0132 & 0.18 & 19.07 & 18.60 \\
\hline ISMIO Frit 202 & 57 & -11.6134 & 1146.47 & 11.90 & 8.50 & 0.0135 & 0.19 & 19.18 & 18.59 \\
\hline ISMIO Frit 202 & 58 & -11.6924 & 1152.91 & 10.59 & 8.65 & 0.0137 & 0.19 & 19.28 & 18.59 \\
\hline ISMIO Frit 202 & 59 & -11.7715 & 1159.22 & 9.38 & 8.80 & 0.0139 & 0.19 & 19.39 & 18.58 \\
\hline ISMIO Frit 202 & 60 & -11.8506 & 1165.42 & 8.25 & 8.95 & 0.0142 & 0.20 & 19.50 & 18.58 \\
\hline
\end{tabular}


WSRC-TR-2004-00200

Revision 0

\section{APPENDIX B}

MAR Results for Nominal Stage Assessments

Using Frit 433 
Table B.1 MAR-Based Assessment Using Frit 433

\begin{tabular}{|c|c|c|}
\hline Glass System & WL (\%) & Fails MAR \\
\hline MST Baseline Frit 433 & 25 & $\Delta \mathrm{G}_{\mathrm{P}} \mathrm{R}_{2} \mathrm{O}$ \\
\hline MST Baseline Frit 433 & 26 & $\Delta \mathrm{G}_{\mathrm{P}} \mathrm{R}_{2} \mathrm{O}$ \\
\hline MST Baseline Frit 433 & 27 & $\Delta \mathrm{G}_{\mathrm{P}} \mathrm{R}_{2} \mathrm{O}$ \\
\hline MST Baseline Frit 433 & 28 & $\Delta \mathrm{G}_{\mathrm{P}} \mathrm{R}_{2} \mathrm{O}$ \\
\hline MST Baseline Frit 433 & 29 & $\Delta \mathrm{G}_{\mathrm{P}}$ \\
\hline MST Baseline Frit 433 & 30 & $\Delta \mathrm{G}_{\mathrm{P}}$ \\
\hline MST Baseline Frit 433 & 31 & $\Delta \mathrm{G}_{\mathrm{P}}$ \\
\hline MST Baseline Frit 433 & 32 & $\Delta \mathrm{G}_{\mathrm{P}}$ \\
\hline MST Baseline Frit 433 & 33 & $\Delta \mathrm{G}_{\mathrm{P}}$ \\
\hline MST Baseline Frit 433 & 34 & $\Delta \mathrm{G}_{\mathrm{P}}$ \\
\hline MST Baseline Frit 433 & 35 & $\Delta \mathrm{G}_{\mathrm{P}}$ \\
\hline MST Baseline Frit 433 & 36 & $\Delta \mathrm{G}_{\mathrm{P}}$ \\
\hline MST Baseline Frit 433 & 37 & $\Delta \mathrm{G}_{\mathrm{P}}$ \\
\hline MST Baseline Frit 433 & 38 & $\Delta \mathrm{G}_{\mathrm{P}}$ \\
\hline MST Baseline Frit 433 & 39 & $\Delta \mathrm{G}_{\mathrm{P}}$ \\
\hline MST Baseline Frit 433 & 40 & $\Delta \mathrm{G}_{\mathrm{P}}$ \\
\hline MST Baseline Frit 433 & 41 & $\Delta \mathrm{G}_{\mathrm{P}}$ lvisc \\
\hline MST Baseline Frit 433 & 42 & $\Delta \mathrm{G}_{\mathrm{P}}$ lvisc \\
\hline MST Baseline Frit 433 & 43 & $\Delta \mathrm{G}_{\mathrm{P}}$ lvisc \\
\hline MST Baseline Frit 433 & 44 & $\Delta \mathrm{G}_{\mathrm{P}}$ lvisc \\
\hline MST Baseline Frit 433 & 45 & $\Delta \mathrm{G}_{\mathrm{P}}$ lvisc \\
\hline MST Baseline Frit 433 & 46 & $\Delta \mathrm{G}_{\mathrm{P}}$ lvisc \\
\hline MST Baseline Frit 433 & 47 & $\Delta \mathrm{G}_{\mathrm{P}}$ lvisc \\
\hline MST Baseline Frit 433 & 48 & $\Delta \mathrm{G}_{\mathrm{P}}$ lvisc \\
\hline MST Baseline Frit 433 & 49 & $\Delta \mathrm{G}_{\mathrm{P}}$ lvisc \\
\hline MST Baseline Frit 433 & 50 & $\Delta \mathrm{G}_{\mathrm{P}}$ lvisc \\
\hline MST Baseline Frit 433 & 51 & $\Delta \mathrm{G}_{\mathrm{P}}$ lvisc \\
\hline MST Baseline Frit 433 & 52 & $\Delta \mathrm{G}_{\mathrm{P}}$ lvisc \\
\hline MST Baseline Frit 433 & 53 & $\Delta \mathrm{G}_{\mathrm{P}}$ lvisc \\
\hline MST Baseline Frit 433 & 54 & $\Delta \mathrm{G}_{\mathrm{P}}$ lvisc $\mathrm{TiO}_{2}$ \\
\hline MST Baseline Frit 433 & 55 & $\Delta \mathrm{G}_{\mathrm{P}} \mathrm{T}_{\mathrm{L}}$ lvisc $\mathrm{TiO}_{2}$ \\
\hline MST Baseline Frit 433 & 56 & $\Delta \mathrm{G}_{\mathrm{P}} \mathrm{T}_{\mathrm{L}}$ lvisc $\mathrm{TiO}_{2}$ \\
\hline MST Baseline Frit 433 & 57 & $\Delta \mathrm{G}_{\mathrm{P}} \mathrm{T}_{\mathrm{L}}$ lvisc $\mathrm{TiO}_{2}$ \\
\hline MST Baseline Frit 433 & 58 & $\Delta \mathrm{G}_{\mathrm{P}} \mathrm{T}_{\mathrm{L}}$ lvisc $\mathrm{TiO}_{2}$ \\
\hline MST Baseline Frit 433 & 59 & $\Delta \mathrm{G}_{\mathrm{P}} \mathrm{T}_{\mathrm{L}}$ lvisc $\mathrm{TiO}_{2}$ \\
\hline MST Baseline Frit 433 & 60 & $\Delta \mathrm{G}_{\mathrm{P}} \mathrm{T}_{\mathrm{L}}$ lvisc $\mathrm{TiO}_{2}$ \\
\hline
\end{tabular}


Table B.1 MAR-Based Assessment Using Frit 433

\begin{tabular}{|c|c|c|}
\hline Glass System & WL (\%) & Fails MAR \\
\hline MST Optimized Frit 433 & 25 & $\Delta \mathrm{G}_{\mathrm{P}} \mathrm{R}_{2} \mathrm{O}$ \\
\hline MST Optimized Frit 433 & 26 & $\Delta \mathrm{G}_{\mathrm{P}} \mathrm{R}_{2} \mathrm{O}$ \\
\hline MST Optimized Frit 433 & 27 & $\Delta \mathrm{G}_{\mathrm{P}} \mathrm{R}_{2} \mathrm{O}$ \\
\hline MST Optimized Frit 433 & 28 & $\Delta \mathrm{G}_{\mathrm{P}}$ \\
\hline MST Optimized Frit 433 & 29 & $\Delta \mathrm{G}_{\mathrm{P}}$ \\
\hline MST Optimized Frit 433 & 30 & $\Delta \mathrm{G}_{\mathrm{P}}$ \\
\hline MST Optimized Frit 433 & 31 & $\Delta \mathrm{G}_{\mathrm{P}}$ \\
\hline MST Optimized Frit 433 & 32 & $\Delta \mathrm{G}_{\mathrm{P}}$ \\
\hline MST Optimized Frit 433 & 33 & $\Delta \mathrm{G}_{\mathrm{P}}$ \\
\hline MST Optimized Frit 433 & 34 & $\Delta \mathrm{G}_{\mathrm{P}}$ \\
\hline MST Optimized Frit 433 & 35 & $\Delta \mathrm{G}_{\mathrm{P}}$ \\
\hline MST Optimized Frit 433 & 36 & $\Delta \mathrm{G}_{\mathrm{P}}$ \\
\hline MST Optimized Frit 433 & 37 & $\Delta \mathrm{G}_{\mathrm{P}}$ \\
\hline MST Optimized Frit 433 & 38 & $\Delta \mathrm{G}_{\mathrm{P}}$ \\
\hline MST Optimized Frit 433 & 39 & $\Delta \mathrm{G}_{\mathrm{P}}$ \\
\hline MST Optimized Frit 433 & 40 & $\Delta \mathrm{G}_{\mathrm{P}}$ \\
\hline MST Optimized Frit 433 & 41 & $\Delta \mathrm{G}_{\mathrm{P}}$ lvisc \\
\hline MST Optimized Frit 433 & 42 & $\Delta \mathrm{G}_{\mathrm{P}}$ lvisc \\
\hline MST Optimized Frit 433 & 43 & $\Delta \mathrm{G}_{\mathrm{P}}$ lvisc \\
\hline MST Optimized Frit 433 & 44 & $\Delta \mathrm{G}_{\mathrm{P}}$ lvisc \\
\hline MST Optimized Frit 433 & 45 & $\Delta \mathrm{G}_{\mathrm{P}}$ lvisc \\
\hline MST Optimized Frit 433 & 46 & $\Delta \mathrm{G}_{\mathrm{P}}$ lvisc \\
\hline MST Optimized Frit 433 & 47 & $\Delta \mathrm{G}_{\mathrm{P}}$ lvisc \\
\hline MST Optimized Frit 433 & 48 & $\Delta \mathrm{G}_{\mathrm{P}}$ lvisc \\
\hline MST Optimized Frit 433 & 49 & $\Delta \mathrm{G}_{\mathrm{p}}$ lvisc \\
\hline MST Optimized Frit 433 & 50 & $\Delta \mathrm{G}_{\mathrm{P}}$ lvisc \\
\hline MST Optimized Frit 433 & 51 & $\Delta \mathrm{G}_{\mathrm{P}}$ lvisc \\
\hline MST Optimized Frit 433 & 52 & $\Delta \mathrm{G}_{\mathrm{P}}$ lvisc \\
\hline MST Optimized Frit 433 & 53 & $\Delta \mathrm{G}_{\mathrm{P}}$ lvisc \\
\hline MST Optimized Frit 433 & 54 & $\Delta \mathrm{G}_{\mathrm{P}} \mathrm{T}_{\mathrm{L}}$ lvisc \\
\hline MST Optimized Frit 433 & 55 & $\Delta \mathrm{G}_{\mathrm{P}} \mathrm{T}_{\mathrm{L}}$ lvisc \\
\hline MST Optimized Frit 433 & 56 & $\Delta \mathrm{G}_{\mathrm{P}} \mathrm{T}_{\mathrm{L}}$ lvisc \\
\hline MST Optimized Frit 433 & 57 & $\Delta \mathrm{G}_{\mathrm{P}} \mathrm{T}_{\mathrm{L}}$ lvisc \\
\hline MST Optimized Frit 433 & 58 & $\Delta \mathrm{G}_{\mathrm{P}} \mathrm{T}_{\mathrm{L}}$ lvisc \\
\hline MST Optimized Frit 433 & 59 & $\Delta \mathrm{G}_{\mathrm{P}} \mathrm{T}_{\mathrm{L}}$ lvisc \\
\hline MST Optimized Frit 433 & 60 & $\Delta \mathrm{G}_{\mathrm{P}} \mathrm{T}_{\mathrm{L}}$ lvisc \\
\hline Engr MST Case A Frit 433 & 25 & $\Delta \mathrm{G}_{\mathrm{P}} \mathrm{R}_{2} \mathrm{O}$ \\
\hline
\end{tabular}


Table B.1 MAR-Based Assessment Using Frit 433

\begin{tabular}{|c|c|c|}
\hline Glass System & WL (\%) & Fails MAR \\
\hline Engr MST Case A Frit 433 & 26 & $\Delta \mathrm{G}_{\mathrm{P}} \mathrm{R}_{2} \mathrm{O}$ \\
\hline Engr MST Case A Frit 433 & 27 & $\Delta \mathrm{G}_{\mathrm{P}} \mathrm{R}_{2} \mathrm{O}$ \\
\hline Engr MST Case A Frit 433 & 28 & $\Delta \mathrm{G}_{\mathrm{P}}$ \\
\hline Engr MST Case A Frit 433 & 29 & $\Delta \mathrm{G}_{\mathrm{P}}$ \\
\hline Engr MST Case A Frit 433 & 30 & $\Delta \mathrm{G}_{\mathrm{P}}$ \\
\hline Engr MST Case A Frit 433 & 31 & $\Delta \mathrm{G}_{\mathrm{P}}$ \\
\hline Engr MST Case A Frit 433 & 32 & $\Delta \mathrm{G}_{\mathrm{P}}$ \\
\hline Engr MST Case A Frit 433 & 33 & $\Delta \mathrm{G}_{\mathrm{P}}$ \\
\hline Engr MST Case A Frit 433 & 34 & $\Delta \mathrm{G}_{\mathrm{P}}$ \\
\hline Engr MST Case A Frit 433 & 35 & $\Delta \mathrm{G}_{\mathrm{P}}$ \\
\hline Engr MST Case A Frit 433 & 36 & $\Delta \mathrm{G}_{\mathrm{P}}$ \\
\hline Engr MST Case A Frit 433 & 37 & $\Delta \mathrm{G}_{\mathrm{P}}$ \\
\hline Engr MST Case A Frit 433 & 38 & $\Delta \mathrm{G}_{\mathrm{P}}$ \\
\hline Engr MST Case A Frit 433 & 39 & $\Delta \mathrm{G}_{\mathrm{P}}$ \\
\hline Engr MST Case A Frit 433 & 40 & $\Delta \mathrm{G}_{\mathrm{P}}$ \\
\hline Engr MST Case A Frit 433 & 41 & $\Delta \mathrm{G}_{\mathrm{P}}$ lvisc \\
\hline Engr MST Case A Frit 433 & 42 & $\Delta \mathrm{G}_{\mathrm{P}}$ lvisc \\
\hline Engr MST Case A Frit 433 & 43 & $\Delta \mathrm{G}_{\mathrm{P}}$ lvisc \\
\hline Engr MST Case A Frit 433 & 44 & $\Delta \mathrm{G}_{\mathrm{P}}$ lvisc \\
\hline Engr MST Case A Frit 433 & 45 & $\Delta \mathrm{G}_{\mathrm{P}}$ lvisc \\
\hline Engr MST Case A Frit 433 & 46 & $\Delta \mathrm{G}_{\mathrm{P}}$ lvisc \\
\hline Engr MST Case A Frit 433 & 47 & $\Delta \mathrm{G}_{\mathrm{P}}$ lvisc \\
\hline Engr MST Case A Frit 433 & 48 & $\Delta \mathrm{G}_{\mathrm{P}}$ lvisc \\
\hline Engr MST Case A Frit 433 & 49 & $\Delta \mathrm{G}_{\mathrm{P}}$ lvisc \\
\hline Engr MST Case A Frit 433 & 50 & $\Delta \mathrm{G}_{\mathrm{P}}$ lvisc \\
\hline Engr MST Case A Frit 433 & 51 & $\Delta \mathrm{G}_{\mathrm{P}}$ lvisc \\
\hline Engr MST Case A Frit 433 & 52 & $\Delta \mathrm{G}_{\mathrm{P}}$ lvisc \\
\hline Engr MST Case A Frit 433 & 53 & $\Delta \mathrm{G}_{\mathrm{P}}$ lvisc \\
\hline Engr MST Case A Frit 433 & 54 & $\Delta \mathrm{G}_{\mathrm{P}} \mathrm{T}_{\mathrm{L}}$ lvisc \\
\hline Engr MST Case A Frit 433 & 55 & $\Delta \mathrm{G}_{\mathrm{P}} \mathrm{T}_{\mathrm{L}}$ lvisc \\
\hline Engr MST Case A Frit 433 & 56 & $\Delta \mathrm{G}_{\mathrm{P}} \mathrm{T}_{\mathrm{L}}$ lvisc \\
\hline Engr MST Case A Frit 433 & 57 & $\Delta \mathrm{G}_{\mathrm{P}} \mathrm{T}_{\mathrm{L}}$ lvisc \\
\hline Engr MST Case A Frit 433 & 58 & $\Delta \mathrm{G}_{\mathrm{P}} \mathrm{T}_{\mathrm{L}}$ lvisc \\
\hline Engr MST Case A Frit 433 & 59 & $\Delta \mathrm{G}_{\mathrm{P}} \mathrm{T}_{\mathrm{L}}$ lvisc \\
\hline Engr MST Case A Frit 433 & 60 & $\Delta \mathrm{G}_{\mathrm{P}} \mathrm{T}_{\mathrm{L}}$ lvisc \\
\hline Engr MST Case B Frit 433 & 25 & - \\
\hline Engr MST Case B Frit 433 & 26 & - \\
\hline
\end{tabular}


Table B.1 MAR-Based Assessment Using Frit 433

\begin{tabular}{|c|c|c|}
\hline Glass System & WL (\%) & Fails MAR \\
\hline Engr MST Case B Frit 433 & 27 & - \\
\hline Engr MST Case B Frit 433 & 28 & - \\
\hline Engr MST Case B Frit 433 & 29 & - \\
\hline Engr MST Case B Frit 433 & 30 & - \\
\hline Engr MST Case B Frit 433 & 31 & - \\
\hline Engr MST Case B Frit 433 & 32 & - \\
\hline Engr MST Case B Frit 433 & 33 & - \\
\hline Engr MST Case B Frit 433 & 34 & - \\
\hline Engr MST Case B Frit 433 & 35 & - \\
\hline Engr MST Case B Frit 433 & 36 & - \\
\hline Engr MST Case B Frit 433 & 37 & - \\
\hline Engr MST Case B Frit 433 & 38 & - \\
\hline Engr MST Case B Frit 433 & 39 & - \\
\hline Engr MST Case B Frit 433 & 40 & - \\
\hline Engr MST Case B Frit 433 & 41 & - \\
\hline Engr MST Case B Frit 433 & 42 & - \\
\hline Engr MST Case B Frit 433 & 43 & - \\
\hline Engr MST Case B Frit 433 & 44 & - \\
\hline Engr MST Case B Frit 433 & 45 & - \\
\hline Engr MST Case B Frit 433 & 46 & - \\
\hline Engr MST Case B Frit 433 & 47 & - \\
\hline Engr MST Case B Frit 433 & 48 & - \\
\hline Engr MST Case B Frit 433 & 49 & - \\
\hline Engr MST Case B Frit 433 & 50 & $\mathrm{~T}_{\mathrm{L}}$ \\
\hline Engr MST Case B Frit 433 & 51 & $\mathrm{~T}_{\mathrm{L}}$ \\
\hline Engr MST Case B Frit 433 & 52 & $\mathrm{~T}_{\mathrm{L}}$ \\
\hline Engr MST Case B Frit 433 & 53 & $\mathrm{~T}_{\mathrm{L}}$ \\
\hline Engr MST Case B Frit 433 & 54 & $\mathrm{~T}_{\mathrm{L}}$ lvisc \\
\hline Engr MST Case B Frit 433 & 55 & $\mathrm{~T}_{\mathrm{L}}$ lvisc \\
\hline Engr MST Case B Frit 433 & 56 & $\mathrm{~T}_{\mathrm{L}}$ lvisc \\
\hline Engr MST Case B Frit 433 & 57 & $\mathrm{~T}_{\mathrm{L}}$ lvisc \\
\hline Engr MST Case B Frit 433 & 58 & $\mathrm{~T}_{\mathrm{L}}$ lvisc \\
\hline Engr MST Case B Frit 433 & 59 & $\mathrm{~T}_{\mathrm{L}}$ lvisc \\
\hline Engr MST Case B Frit 433 & 60 & $\mathrm{~T}_{\mathrm{L}}$ lvisc \\
\hline ISMIO Frit 433 & 25 & $\Delta \mathrm{G}_{\mathrm{P}} \mathrm{R}_{2} \mathrm{O}$ \\
\hline ISMIO Frit 433 & 26 & $\Delta \mathrm{G}_{\mathrm{P}} \mathrm{R}_{2} \mathrm{O}$ \\
\hline ISMIO Frit 433 & 27 & $\Delta \mathrm{G}_{\mathrm{P}} \mathrm{R}_{2} \mathrm{O}$ \\
\hline
\end{tabular}


Table B.1 MAR-Based Assessment Using Frit 433

\begin{tabular}{|c|c|c|}
\hline Glass System & WL (\%) & Fails MAR \\
\hline ISMIO Frit 433 & 28 & $\Delta \mathrm{G}_{\mathrm{P}} \mathrm{R}_{2} \mathrm{O}$ \\
\hline ISMIO Frit 433 & 29 & $\Delta \mathrm{G}_{\mathrm{P}}$ \\
\hline ISMIO Frit 433 & 30 & $\Delta \mathrm{G}_{\mathrm{P}}$ \\
\hline ISMIO Frit 433 & 31 & $\Delta \mathrm{G}_{\mathrm{P}}$ \\
\hline ISMIO Frit 433 & 32 & $\Delta \mathrm{G}_{\mathrm{P}}$ \\
\hline ISMIO Frit 433 & 33 & $\Delta \mathrm{G}_{\mathrm{P}}$ \\
\hline ISMIO Frit 433 & 34 & $\Delta \mathrm{G}_{\mathrm{P}}$ \\
\hline ISMIO Frit 433 & 35 & $\Delta \mathrm{G}_{\mathrm{P}}$ \\
\hline ISMIO Frit 433 & 36 & $\Delta \mathrm{G}_{\mathrm{P}}$ \\
\hline ISMIO Frit 433 & 37 & $\Delta \mathrm{G}_{\mathrm{P}}$ \\
\hline ISMIO Frit 433 & 38 & $\Delta \mathrm{G}_{\mathrm{P}}$ \\
\hline ISMIO Frit 433 & 39 & $\Delta \mathrm{G}_{\mathrm{P}}$ \\
\hline ISMIO Frit 433 & 40 & $\Delta \mathrm{G}_{\mathrm{P}}$ \\
\hline ISMIO Frit 433 & 41 & $\Delta \mathrm{G}_{\mathrm{P}}$ lvisc \\
\hline ISMIO Frit 433 & 42 & $\Delta \mathrm{G}_{\mathrm{P}}$ lvisc \\
\hline ISMIO Frit 433 & 43 & $\Delta \mathrm{G}_{\mathrm{P}}$ lvisc \\
\hline ISMIO Frit 433 & 44 & $\Delta \mathrm{G}_{\mathrm{P}}$ lvisc \\
\hline ISMIO Frit 433 & 45 & $\Delta \mathrm{G}_{\mathrm{P}}$ lvisc \\
\hline ISMIO Frit 433 & 46 & $\Delta \mathrm{G}_{\mathrm{P}}$ lvisc \\
\hline ISMIO Frit 433 & 47 & $\Delta \mathrm{G}_{\mathrm{P}}$ lvisc \\
\hline ISMIO Frit 433 & 48 & $\Delta \mathrm{G}_{\mathrm{P}}$ lvisc \\
\hline ISMIO Frit 433 & 49 & $\Delta \mathrm{G}_{\mathrm{P}}$ lvisc \\
\hline ISMIO Frit 433 & 50 & $\Delta \mathrm{G}_{\mathrm{P}}$ lvisc \\
\hline ISMIO Frit 433 & 51 & $\Delta \mathrm{G}_{\mathrm{P}}$ lvisc \\
\hline ISMIO Frit 433 & 52 & $\Delta \mathrm{G}_{\mathrm{P}} \mathrm{T}_{\mathrm{L}}$ lvisc \\
\hline ISMIO Frit 433 & 53 & $\Delta \mathrm{G}_{\mathrm{P}} \mathrm{T}_{\mathrm{L}}$ lvisc \\
\hline ISMIO Frit 433 & 54 & $\Delta \mathrm{G}_{\mathrm{P}} \mathrm{T}_{\mathrm{L}}$ lvisc \\
\hline ISMIO Frit 433 & 55 & $\Delta \mathrm{G}_{\mathrm{P}} \mathrm{T}_{\mathrm{L}}$ lvisc \\
\hline ISMIO Frit 433 & 56 & $\Delta \mathrm{G}_{\mathrm{P}} \mathrm{T}_{\mathrm{L}}$ lvisc \\
\hline ISMIO Frit 433 & 57 & $\Delta \mathrm{G}_{\mathrm{P}} \mathrm{T}_{\mathrm{L}}$ lvisc \\
\hline ISMIO Frit 433 & 58 & $\Delta \mathrm{G}_{\mathrm{P}} \mathrm{T}_{\mathrm{L}}$ lvisc \\
\hline ISMIO Frit 433 & 59 & $\Delta \mathrm{G}_{\mathrm{P}} \mathrm{T}_{\mathrm{L}}$ lvisc \\
\hline ISMIO Frit 433 & 60 & $\Delta \mathrm{G}_{\mathrm{P}} \mathrm{T}_{\mathrm{L}}$ lvisc \\
\hline
\end{tabular}


Table B.2 Property Predictions Using Frit 433

\begin{tabular}{|c|c|c|c|c|c|c|c|c|}
\hline Glass System & $\begin{array}{l}\text { WL } \\
(\%) \\
\end{array}$ & $\begin{array}{c}\text { B Del Gp } \\
\text { Value }\end{array}$ & $\begin{array}{c}\begin{array}{c}\text { TL Pred } \\
\left({ }^{\circ} \mathrm{C}\right)\end{array} \\
\end{array}$ & $\begin{array}{c}\text { Visc Pred } \\
\text { (P) } \\
\end{array}$ & $\begin{array}{c}\text { Al2O3 } \\
\text { wt \% }\end{array}$ & $\begin{array}{l}\text { TiO2 } \\
\text { wt\% } \\
\end{array}$ & $\begin{array}{c}\text { Na2SO4 } \\
\text { wt } \% \\
\end{array}$ & $\begin{array}{l}\text { R2O } \\
\text { wt \% } \\
\end{array}$ \\
\hline MST Baseline Frit 433 & 25 & -13.6159 & 697.64 & 55.20 & 3.66 & 0.89 & 0.02 & 21.02 \\
\hline MST Baseline Frit 433 & 26 & -13.6319 & 711.93 & 52.93 & 3.81 & 0.93 & 0.03 & 21.06 \\
\hline MST Baseline Frit 433 & 27 & -13.6478 & 725.90 & 50.70 & 3.95 & 0.97 & 0.03 & 21.10 \\
\hline MST Baseline Frit 433 & 28 & -13.6638 & 739.51 & 48.50 & 4.10 & 1.00 & 0.03 & 21.14 \\
\hline MST Baseline Frit 433 & 29 & -13.6798 & 752.85 & 46.35 & 4.25 & 1.04 & 0.03 & 21.19 \\
\hline MST Baseline Frit 433 & 30 & -13.6957 & 765.90 & 44.24 & 4.39 & 1.07 & 0.03 & 21.23 \\
\hline MST Baseline Frit 433 & 31 & -13.7116 & 778.66 & 42.17 & 4.54 & 1.11 & 0.03 & 21.27 \\
\hline MST Baseline Frit 433 & 32 & -13.7276 & 791.12 & 40.15 & 4.69 & 1.14 & 0.03 & 21.31 \\
\hline MST Baseline Frit 433 & 33 & -13.7435 & 803.35 & 38.17 & 4.83 & 1.18 & 0.03 & 21.35 \\
\hline MST Baseline Frit 433 & 34 & -13.7595 & 815.34 & 36.23 & 4.98 & 1.22 & 0.03 & 21.39 \\
\hline MST Baseline Frit 433 & 35 & -13.7755 & 827.08 & 34.34 & 5.13 & 1.25 & 0.03 & 21.43 \\
\hline MST Baseline Frit 433 & 36 & -13.7914 & 838.57 & 32.50 & 5.27 & 1.29 & 0.04 & 21.47 \\
\hline MST Baseline Frit 433 & 37 & -13.8073 & 849.85 & 30.70 & 5.42 & 1.32 & 0.04 & 21.51 \\
\hline MST Baseline Frit 433 & 38 & -13.8234 & 860.92 & 28.96 & 5.57 & 1.36 & 0.04 & 21.55 \\
\hline MST Baseline Frit 433 & 39 & -13.8393 & 871.78 & 27.26 & 5.71 & 1.40 & 0.04 & 21.59 \\
\hline MST Baseline Frit 433 & 40 & -13.8553 & 882.40 & 25.62 & 5.86 & 1.43 & 0.04 & 21.64 \\
\hline MST Baseline Frit 433 & 41 & -13.8711 & 892.86 & 24.02 & 6.01 & 1.47 & 0.04 & 21.68 \\
\hline MST Baseline Frit 433 & 42 & -13.8871 & 903.13 & 22.48 & 6.15 & 1.50 & 0.04 & 21.72 \\
\hline MST Baseline Frit 433 & 43 & -13.9030 & 913.19 & 20.99 & 6.30 & 1.54 & 0.04 & 21.76 \\
\hline MST Baseline Frit 433 & 44 & -13.9189 & 923.09 & 19.56 & 6.44 & 1.57 & 0.04 & 21.80 \\
\hline MST Baseline Frit 433 & 45 & -13.9349 & 932.81 & 18.18 & 6.59 & 1.61 & 0.04 & 21.84 \\
\hline MST Baseline Frit 433 & 46 & -13.9509 & 942.37 & 16.85 & 6.74 & 1.65 & 0.04 & 21.88 \\
\hline MST Baseline Frit 433 & 47 & -13.9668 & 951.73 & 15.58 & 6.88 & 1.68 & 0.05 & 21.92 \\
\hline
\end{tabular}


Table B.2 Property Predictions Using Frit 433

\begin{tabular}{|c|c|c|c|c|c|c|c|c|}
\hline Glass System & $\begin{array}{l}\text { WL } \\
\text { (\%) }\end{array}$ & $\begin{array}{c}\text { B Del Gp } \\
\text { Value }\end{array}$ & $\begin{array}{c}\text { TL Pred } \\
\left({ }^{\circ} \mathrm{C}\right)\end{array}$ & $\begin{array}{c}\text { Visc Pred } \\
\text { (P) }\end{array}$ & $\begin{array}{c}\text { Al2O3 } \\
\text { wt } \%\end{array}$ & $\begin{array}{l}\text { TiO2 } \\
\text { wt\% }\end{array}$ & $\begin{array}{c}\text { Na2SO4 } \\
\text { wt } \%\end{array}$ & $\begin{array}{l}\text { R2O } \\
\text { wt \% }\end{array}$ \\
\hline MST Baseline Frit 433 & 48 & -13.9828 & 960.97 & 14.37 & 7.03 & 1.72 & 0.05 & 21.96 \\
\hline MST Baseline Frit 433 & 50 & -14.0147 & 978.97 & 12.10 & 7.32 & 1.79 & 0.05 & 22.04 \\
\hline MST Baseline Frit 433 & 51 & -14.0307 & 987.72 & 11.06 & 7.47 & 1.82 & 0.05 & 22.09 \\
\hline MST Baseline Frit 433 & 54 & -14.0786 & 1013.17 & 8.24 & 7.91 & 1.93 & 0.05 & 22.21 \\
\hline MST Baseline Frit 433 & 55 & -14.0945 & 1021.39 & 7.42 & 8.06 & 1.97 & 0.05 & 22.25 \\
\hline MST Baseline Frit 433 & 56 & -14.1105 & 1029.49 & 6.64 & 8.20 & 2.00 & 0.05 & 22.29 \\
\hline MST Baseline Frit 433 & 57 & -14.1263 & 1037.46 & 5.92 & 8.35 & 2.04 & 0.06 & 22.33 \\
\hline MST Baseline Frit 433 & 60 & -14.1742 & 1060.60 & 4.06 & 8.79 & 2.15 & 0.06 & 22.45 \\
\hline MST Optimized Frit 433 & 25 & -13.7625 & 698.45 & 54.71 & 3.78 & 0.24 & 0.03 & 21.09 \\
\hline MST Optimized Frit 433 & 26 & -13.7842 & 713.03 & 52.44 & 3.93 & 0.25 & 0.03 & 21.13 \\
\hline MST Optimized Frit 433 & 27 & -13.8061 & 727.30 & 50.21 & 4.08 & 0.26 & 0.03 & 21.17 \\
\hline MST Optimized Frit 433 & 28 & -13.8279 & 741.23 & 48.01 & 4.23 & 0.27 & 0.03 & 21.22 \\
\hline MST Optimized Frit 433 & 29 & -13.8498 & 754.90 & 45.86 & 4.39 & 0.28 & 0.03 & 21.26 \\
\hline MST Optimized Frit 433 & 30 & -13.8716 & 768.25 & 43.75 & 4.54 & 0.29 & 0.03 & 21.30 \\
\hline MST Optimized Frit 433 & 31 & -13.8934 & 781.35 & 41.69 & 4.69 & 0.30 & 0.03 & 21.35 \\
\hline MST Optimized Frit 433 & 32 & -13.9151 & 794.17 & 39.66 & 4.84 & 0.31 & 0.03 & 21.39 \\
\hline
\end{tabular}


Table B.2 Property Predictions Using Frit 433

\begin{tabular}{|c|c|c|c|c|c|c|c|c|}
\hline Glass System & $\begin{array}{l}\text { WL } \\
(\%)\end{array}$ & $\begin{array}{l}\text { B Del Gp } \\
\text { Value }\end{array}$ & $\begin{array}{c}\text { TL Pred } \\
\left({ }^{\circ} \mathbf{C}\right)\end{array}$ & $\begin{array}{l}\text { Visc Pred } \\
\text { (P) }\end{array}$ & $\begin{array}{c}\text { Al2O3 } \\
\text { wt \% }\end{array}$ & $\begin{array}{l}\text { TiO2 } \\
\text { wt \% }\end{array}$ & $\begin{array}{c}\text { Na2SO4 } \\
\text { wt } \%\end{array}$ & $\begin{array}{l}\text { R2O } \\
\text { wt \% }\end{array}$ \\
\hline MST Optimized Frit 433 & 36 & -14.0024 & 843.01 & 32.03 & 5.44 & 0.35 & 0.04 & 21.56 \\
\hline MST Optimized Frit 433 & 37 & -14.0243 & 854.67 & 30.25 & 5.60 & 0.36 & 0.04 & 21.61 \\
\hline MST Optimized Frit 433 & 38 & -14.0460 & 866.08 & 28.51 & 5.75 & 0.36 & 0.04 & 21.65 \\
\hline MST Optimized Frit 433 & 39 & -14.0678 & 877.29 & 26.83 & 5.90 & 0.37 & 0.04 & 21.69 \\
\hline MST Optimized Frit 433 & 40 & -14.0897 & 888.32 & 25.19 & 6.05 & 0.38 & 0.04 & 21.74 \\
\hline MST Optimized Frit 433 & 41 & -14.1115 & 899.13 & 23.61 & 6.20 & 0.39 & 0.04 & 21.78 \\
\hline MST Optimized Frit 433 & 42 & -14.1334 & 909.79 & 22.08 & 6.35 & 0.40 & 0.04 & 21.82 \\
\hline MST Optimized Frit 433 & 43 & -14.1552 & 920.23 & 20.61 & 6.50 & 0.41 & 0.04 & 21.87 \\
\hline MST Optimized Frit 433 & 44 & -14.1769 & 930.52 & 19.18 & 6.65 & 0.42 & 0.04 & 21.91 \\
\hline MST Optimized Frit 433 & 45 & -14.1987 & 940.61 & 17.82 & 6.81 & 0.43 & 0.05 & 21.96 \\
\hline MST Optimized Frit 433 & 46 & -14.2205 & 950.56 & 16.51 & 6.96 & 0.44 & 0.05 & 22.00 \\
\hline MST Optimized Frit 433 & 47 & -14.2423 & 960.32 & 15.25 & 7.11 & 0.45 & 0.05 & 22.04 \\
\hline MST Optimized Frit 433 & 48 & -14.2642 & 969.95 & 14.05 & 7.26 & 0.46 & 0.05 & 22.09 \\
\hline MST Optimized Frit 433 & 49 & -14.2859 & 979.39 & 12.91 & 7.41 & 0.47 & 0.05 & 22.13 \\
\hline MST Optimized Frit 433 & 50 & -14.3077 & 988.72 & 11.82 & 7.56 & 0.48 & 0.05 & 22.17 \\
\hline MST Optimized Frit 433 & 51 & -14.3296 & 997.87 & 10.79 & 7.71 & 0.49 & 0.05 & 22.22 \\
\hline MST Optimized Frit 433 & 52 & -14.3514 & 1006.90 & 9.81 & 7.86 & 0.50 & 0.05 & 22.26 \\
\hline MST Optimized Frit 433 & 53 & -14.3733 & 1015.77 & 8.89 & 8.02 & 0.51 & 0.05 & 22.30 \\
\hline MST Optimized Frit 433 & 54 & -14.3950 & 1024.53 & 8.02 & 8.17 & 0.52 & 0.05 & 22.35 \\
\hline MST Optimized Frit 433 & 55 & -14.4168 & 1033.13 & 7.21 & 8.32 & 0.53 & 0.06 & 22.39 \\
\hline MST Optimized Frit 433 & 56 & -14.4386 & 1041.62 & 6.45 & 8.47 & 0.54 & 0.06 & 22.43 \\
\hline MST Optimized Frit 433 & 57 & -14.4605 & 1049.96 & 5.74 & 8.62 & 0.55 & 0.06 & 22.48 \\
\hline MST Optimized Frit 433 & 58 & -14.4823 & 1058.19 & 5.09 & 8.77 & 0.56 & 0.06 & 22.52 \\
\hline MST Optimized Frit 433 & 59 & -14.5041 & 1066.31 & 4.48 & 8.92 & 0.57 & 0.06 & 22.56 \\
\hline
\end{tabular}


Table B.2 Property Predictions Using Frit 433

\begin{tabular}{|c|c|c|c|c|c|c|c|c|}
\hline Glass System & $\begin{array}{l}\text { WL } \\
\text { (\%) }\end{array}$ & $\begin{array}{c}\text { B Del Gp } \\
\text { Value }\end{array}$ & $\begin{array}{c}\text { TL Pred } \\
\left({ }^{\circ} \mathrm{C}\right)\end{array}$ & $\begin{array}{c}\text { Visc Pred } \\
\text { (P) }\end{array}$ & $\begin{array}{c}\text { Al2O3 } \\
\text { wt } \%\end{array}$ & $\begin{array}{l}\text { TiO2 } \\
\text { wt\% }\end{array}$ & $\begin{array}{c}\text { Na2SO4 } \\
\text { wt } \% \\
\end{array}$ & $\begin{array}{l}\text { R2O } \\
\text { wt \% }\end{array}$ \\
\hline MST Optimized Frit 433 & 60 & -14.5259 & 1074.29 & 3.93 & 9.07 & 0.58 & 0.06 & 22.61 \\
\hline Engr MST Case A Frit 433 & 25 & -13.6304 & 700.64 & 55.45 & 3.74 & 0.52 & 0.02 & 20.98 \\
\hline Engr MST Case A Frit 433 & 26 & -13.6469 & 715.18 & 53.19 & 3.89 & 0.54 & 0.03 & 21.02 \\
\hline Engr MST Case A Frit 433 & 27 & -13.6635 & 729.42 & 50.96 & 4.04 & 0.56 & 0.03 & 21.06 \\
\hline Engr MST Case A Frit 433 & 28 & -13.6800 & 743.31 & 48.77 & 4.19 & 0.58 & 0.03 & 21.10 \\
\hline Engr MST Case A Frit 433 & 29 & -13.6965 & 756.90 & 46.62 & 4.34 & 0.60 & 0.03 & 21.14 \\
\hline Engr MST Case A Frit 433 & 30 & -13.7131 & 770.21 & 44.51 & 4.49 & 0.62 & 0.03 & 21.18 \\
\hline Engr MST Case A Frit 433 & 31 & -13.7296 & 783.26 & 42.44 & 4.64 & 0.64 & 0.03 & 21.22 \\
\hline Engr MST Case A Frit 433 & 32 & -13.7461 & 796.02 & 40.42 & 4.79 & 0.66 & 0.03 & 21.26 \\
\hline Engr MST Case A Frit 433 & 33 & -13.7627 & 808.52 & 38.43 & 4.94 & 0.68 & 0.03 & 21.30 \\
\hline Engr MST Case A Frit 433 & 34 & -13.7791 & 820.77 & 36.50 & 5.09 & 0.70 & 0.03 & 21.34 \\
\hline Engr MST Case A Frit 433 & 35 & -13.7957 & 832.81 & 34.60 & 5.24 & 0.72 & 0.03 & 21.38 \\
\hline Engr MST Case A Frit 433 & 36 & -13.8123 & 844.59 & 32.76 & 5.39 & 0.74 & 0.04 & 21.41 \\
\hline Engr MST Case A Frit 433 & 37 & -13.8288 & 856.15 & 30.96 & 5.54 & 0.77 & 0.04 & 21.45 \\
\hline Engr MST Case A Frit 433 & 38 & -13.8453 & 867.49 & 29.21 & 5.69 & 0.79 & 0.04 & 21.49 \\
\hline Engr MST Case A Frit 433 & 39 & -13.8619 & 878.66 & 27.51 & 5.84 & 0.81 & 0.04 & 21.53 \\
\hline Engr MST Case A Frit 433 & 40 & -13.8783 & 889.60 & 25.86 & 5.99 & 0.83 & 0.04 & 21.57 \\
\hline Engr MST Case A Frit 433 & 41 & -13.8949 & 900.33 & 24.27 & 6.14 & 0.85 & 0.04 & 21.61 \\
\hline Engr MST Case A Frit 433 & 42 & -13.9114 & 910.87 & 22.72 & 6.29 & 0.87 & 0.04 & 21.65 \\
\hline Engr MST Case A Frit 433 & 43 & -13.9279 & 921.27 & 21.23 & 6.44 & 0.89 & 0.04 & 21.69 \\
\hline Engr MST Case A Frit 433 & 44 & -13.9445 & 931.44 & 19.79 & 6.59 & 0.91 & 0.04 & 21.73 \\
\hline Engr MST Case A Frit 433 & 45 & -13.9611 & 941.45 & 18.40 & 6.74 & 0.93 & 0.04 & 21.77 \\
\hline Engr MST Case A Frit 433 & 46 & -13.9774 & 951.29 & 17.07 & 6.89 & 0.95 & 0.05 & 21.81 \\
\hline Engr MST Case A Frit 433 & 47 & -13.9940 & 961.00 & 15.79 & 7.04 & 0.97 & 0.05 & 21.85 \\
\hline
\end{tabular}


Table B.2 Property Predictions Using Frit 433

\begin{tabular}{|c|c|c|c|c|c|c|c|c|}
\hline Glass System & $\begin{array}{l}\text { WL } \\
\text { (\%) }\end{array}$ & $\begin{array}{c}\text { B Del Gp } \\
\text { Value }\end{array}$ & $\begin{array}{c}\text { TL Pred } \\
\left({ }^{\circ} \mathbf{C}\right)\end{array}$ & $\begin{array}{c}\text { Visc Pred } \\
\text { (P) }\end{array}$ & $\begin{array}{c}\text { Al2O3 } \\
\text { wt } \%\end{array}$ & $\begin{array}{l}\text { TiO2 } \\
\text { wt \% }\end{array}$ & $\begin{array}{c}\text { Na2SO4 } \\
\text { wt } \%\end{array}$ & $\begin{array}{l}\text { R2O } \\
\text { wt \% }\end{array}$ \\
\hline Engr MST Case A Frit 433 & 48 & -14.0106 & 970.51 & 14.57 & 7.19 & 0.99 & 0.05 & 21.89 \\
\hline Engr MST Case A Frit 433 & 49 & -14.0271 & 979.87 & 13.40 & 7.34 & 1.01 & 0.05 & 21.93 \\
\hline Engr MST Case A Frit 433 & 50 & -14.0437 & 989.08 & 12.29 & 7.49 & 1.03 & 0.05 & 21.97 \\
\hline Engr MST Case A Frit 433 & 51 & -14.0602 & 998.16 & 11.23 & 7.64 & 1.05 & 0.05 & 22.00 \\
\hline Engr MST Case A Frit 433 & 52 & -14.0767 & 1007.08 & 10.23 & 7.79 & 1.08 & 0.05 & 22.04 \\
\hline Engr MST Case A Frit 433 & 53 & -14.0932 & 1015.85 & 9.29 & 7.94 & 1.10 & 0.05 & 22.08 \\
\hline Engr MST Case A Frit 433 & 54 & -14.1097 & 1024.49 & 8.39 & 8.09 & 1.12 & 0.05 & 22.12 \\
\hline Engr MST Case A Frit 433 & 55 & -14.1263 & 1033.02 & 7.56 & 8.24 & 1.14 & 0.05 & 22.16 \\
\hline Engr MST Case A Frit 433 & 56 & -14.1429 & 1041.40 & 6.77 & 8.39 & 1.16 & 0.06 & 22.20 \\
\hline Engr MST Case A Frit 433 & 57 & -14.1594 & 1049.64 & 6.04 & 8.54 & 1.18 & 0.06 & 22.24 \\
\hline Engr MST Case A Frit 433 & 58 & -14.1758 & 1057.77 & 5.37 & 8.69 & 1.20 & 0.06 & 22.28 \\
\hline Engr MST Case A Frit 433 & 59 & -14.1924 & 1065.80 & 4.74 & 8.84 & 1.22 & 0.06 & 22.32 \\
\hline Engr MST Case A Frit 433 & 60 & -14.2089 & 1073.69 & 4.16 & 8.99 & 1.24 & 0.06 & 22.36 \\
\hline Engr MST Case B Frit 433 & 25 & -12.1307 & 736.55 & 76.11 & 6.31 & 0.31 & 0.02 & 20.30 \\
\hline Engr MST Case B Frit 433 & 26 & -12.0873 & 751.46 & 74.24 & 6.56 & 0.32 & 0.02 & 20.31 \\
\hline Engr MST Case B Frit 433 & 27 & -12.0438 & 766.02 & 72.38 & 6.81 & 0.34 & 0.02 & 20.32 \\
\hline Engr MST Case B Frit 433 & 28 & -12.0003 & 780.18 & 70.51 & 7.07 & 0.35 & 0.02 & 20.33 \\
\hline Engr MST Case B Frit 433 & 29 & -11.9568 & 794.03 & 68.64 & 7.32 & 0.36 & 0.03 & 20.35 \\
\hline Engr MST Case B Frit 433 & 30 & -11.9134 & 807.54 & 66.77 & 7.57 & 0.37 & 0.03 & 20.36 \\
\hline Engr MST Case B Frit 433 & 31 & -11.8700 & 820.69 & 64.90 & 7.82 & 0.38 & 0.03 & 20.37 \\
\hline Engr MST Case B Frit 433 & 32 & -11.8265 & 833.56 & 63.03 & 8.08 & 0.40 & 0.03 & 20.38 \\
\hline Engr MST Case B Frit 433 & 33 & -11.7831 & 846.11 & 61.17 & 8.33 & 0.41 & 0.03 & 20.39 \\
\hline Engr MST Case B Frit 433 & 34 & -11.7396 & 858.40 & 59.31 & 8.58 & 0.42 & 0.03 & 20.41 \\
\hline Engr MST Case B Frit 433 & 35 & -11.6961 & 870.40 & 57.46 & 8.83 & 0.43 & 0.03 & 20.42 \\
\hline
\end{tabular}


Table B.2 Property Predictions Using Frit 433

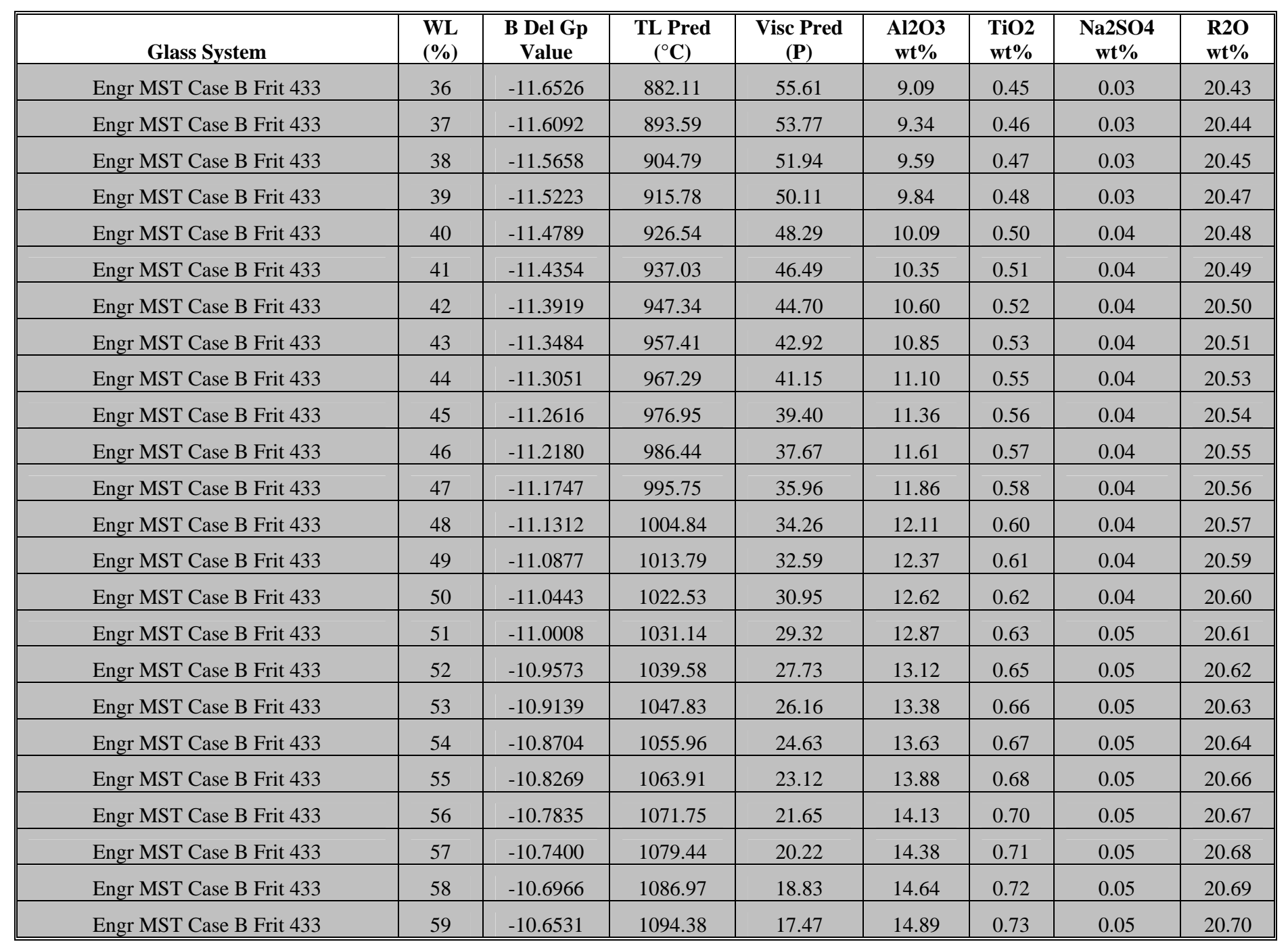


Table B.2 Property Predictions Using Frit 433

\begin{tabular}{|c|c|c|c|c|c|c|c|c|}
\hline Glass System & $\begin{array}{l}\text { WL } \\
(\%)\end{array}$ & $\begin{array}{c}\text { B Del Gp } \\
\text { Value }\end{array}$ & $\begin{array}{c}\text { TL Pred } \\
\left({ }^{\circ} \mathrm{C}\right)\end{array}$ & $\begin{array}{l}\text { Visc Pred } \\
\text { (P) }\end{array}$ & $\begin{array}{c}\text { Al2O3 } \\
\text { wt } \%\end{array}$ & $\begin{array}{l}\text { TiO2 } \\
\text { wt } \%\end{array}$ & $\begin{array}{c}\text { Na2SO4 } \\
\text { wt } \%\end{array}$ & $\begin{array}{l}\text { R2O } \\
\text { wt \% }\end{array}$ \\
\hline Engr MST Case B Frit 433 & 60 & -10.6096 & 1101.64 & 16.16 & 15.14 & 0.75 & 0.05 & 20.72 \\
\hline ISMIO Frit 433 & 25 & -13.6662 & 705.70 & 54.07 & 3.73 & 0.01 & 0.08 & 20.96 \\
\hline ISMIO Frit 433 & 26 & -13.6843 & 720.54 & 51.80 & 3.88 & 0.01 & 0.09 & 21.00 \\
\hline ISMIO Frit 433 & 27 & -13.7022 & 735.07 & 49.56 & 4.03 & 0.01 & 0.09 & 21.04 \\
\hline ISMIO Frit 433 & 28 & -13.7201 & 749.27 & 47.36 & 4.18 & 0.01 & 0.09 & 21.07 \\
\hline ISMIO Frit 433 & 29 & -13.7382 & 763.19 & 45.21 & 4.33 & 0.01 & 0.10 & 21.11 \\
\hline ISMIO Frit 433 & 30 & -13.7561 & 776.84 & 43.10 & 4.48 & 0.01 & 0.10 & 21.15 \\
\hline ISMIO Frit 433 & 31 & -13.7740 & 790.19 & 41.03 & 4.63 & 0.01 & 0.10 & 21.19 \\
\hline ISMIO Frit 433 & 32 & -13.7920 & 803.27 & 39.01 & 4.77 & 0.01 & 0.11 & 21.23 \\
\hline ISMIO Frit 433 & 33 & -13.8100 & 816.10 & 37.04 & 4.92 & 0.01 & 0.11 & 21.27 \\
\hline ISMIO Frit 433 & 34 & -13.8279 & 828.69 & 35.11 & 5.07 & 0.01 & 0.11 & 21.30 \\
\hline ISMIO Frit 433 & 35 & -13.8459 & 841.03 & 33.23 & 5.22 & 0.01 & 0.11 & 21.34 \\
\hline ISMIO Frit 433 & 36 & -13.8639 & 853.18 & 31.41 & 5.37 & 0.01 & 0.12 & 21.38 \\
\hline ISMIO Frit 433 & 37 & -13.8819 & 865.07 & 29.63 & 5.52 & 0.01 & 0.12 & 21.42 \\
\hline ISMIO Frit 433 & 38 & -13.8998 & 876.76 & 27.90 & 5.67 & 0.01 & 0.12 & 21.46 \\
\hline ISMIO Frit 433 & 39 & -13.9178 & 888.23 & 26.23 & 5.82 & 0.01 & 0.13 & 21.50 \\
\hline ISMIO Frit 433 & 40 & -13.9357 & 899.50 & 24.61 & 5.97 & 0.01 & 0.13 & 21.53 \\
\hline ISMIO Frit 433 & 41 & -13.9536 & 910.58 & 23.04 & 6.12 & 0.01 & 0.13 & 21.57 \\
\hline ISMIO Frit 433 & 42 & -13.9716 & 921.46 & 21.52 & 6.27 & 0.01 & 0.14 & 21.61 \\
\hline ISMIO Frit 433 & 43 & -13.9897 & 932.19 & 20.07 & 6.42 & 0.01 & 0.14 & 21.65 \\
\hline ISMIO Frit 433 & 44 & -14.0076 & 942.72 & 18.66 & 6.56 & 0.01 & 0.14 & 21.69 \\
\hline ISMIO Frit 433 & 45 & -14.0256 & 953.06 & 17.31 & 6.71 & 0.01 & 0.15 & 21.73 \\
\hline ISMIO Frit 433 & 46 & -14.0436 & 963.25 & 16.02 & 6.86 & 0.01 & 0.15 & 21.76 \\
\hline ISMIO Frit 433 & 47 & -14.0615 & 973.26 & 14.78 & 7.01 & 0.01 & 0.15 & 21.80 \\
\hline
\end{tabular}


Table B.2 Property Predictions Using Frit 433

\begin{tabular}{|c|c|c|c|c|c|c|c|c|}
\hline Glass System & $\begin{array}{l}\text { WL } \\
\text { (\%) }\end{array}$ & $\begin{array}{c}\text { B Del Gp } \\
\text { Value }\end{array}$ & $\begin{array}{c}\text { TL Pred } \\
\left({ }^{\circ} \mathrm{C}\right)\end{array}$ & $\begin{array}{c}\text { Visc Pred } \\
\text { (P) }\end{array}$ & $\begin{array}{c}\text { Al2O3 } \\
\text { wt } \%\end{array}$ & $\begin{array}{l}\text { TiO2 } \\
\text { wt \% }\end{array}$ & $\begin{array}{c}\text { Na2SO4 } \\
\text { wt } \%\end{array}$ & $\begin{array}{l}\text { R2O } \\
\text { wt \% }\end{array}$ \\
\hline ISMIO Frit 433 & 48 & -14.0794 & 983.12 & 13.60 & 7.16 & 0.01 & 0.16 & 21.84 \\
\hline ISMIO Frit 433 & 49 & -14.0974 & 992.85 & 12.48 & 7.31 & 0.01 & 0.16 & 21.88 \\
\hline ISMIO Frit 433 & 50 & -14.1154 & 1002.40 & 11.41 & 7.46 & 0.01 & 0.16 & 21.92 \\
\hline ISMIO Frit 433 & 51 & -14.1333 & 1011.80 & 10.40 & 7.61 & 0.01 & 0.17 & 21.96 \\
\hline ISMIO Frit 433 & 52 & -14.1513 & 1021.05 & 9.44 & 7.76 & 0.01 & 0.17 & 21.99 \\
\hline ISMIO Frit 433 & 53 & -14.1693 & 1030.17 & 8.54 & 7.91 & 0.01 & 0.17 & 22.03 \\
\hline ISMIO Frit 433 & 54 & -14.1872 & 1039.15 & 7.70 & 8.06 & 0.01 & 0.18 & 22.07 \\
\hline ISMIO Frit 433 & 55 & -14.2051 & 1047.99 & 6.91 & 8.21 & 0.01 & 0.18 & 22.11 \\
\hline ISMIO Frit 433 & 56 & -14.2231 & 1056.73 & 6.17 & 8.35 & 0.01 & 0.18 & 22.15 \\
\hline ISMIO Frit 433 & 57 & -14.2411 & 1065.31 & 5.48 & 8.50 & 0.01 & 0.19 & 22.19 \\
\hline ISMIO Frit 433 & 58 & -14.2591 & 1073.77 & 4.85 & 8.65 & 0.01 & 0.19 & 22.22 \\
\hline ISMIO Frit 433 & 59 & -14.2770 & 1082.11 & 4.26 & 8.80 & 0.01 & 0.19 & 22.26 \\
\hline ISMIO Frit 433 & 60 & -14.2950 & 1090.33 & 3.73 & 8.95 & 0.01 & 0.20 & 22.30 \\
\hline
\end{tabular}

